\title{
Alaska Resource Data File, Nabesna quadrangle, Alaska
}

By Travis L. Hudson ${ }^{1}$

Open-File Report 03-446

2003

This report is preliminary and has not been reviewed for conformity with U.S. Geological Survey editorial standards or with the North American Stratigraphic Code. Any use of trade, firm, or product names is for descriptive purposes only and does not imply endorsement by the U.S. Government.

U.S. DEPARTMENT OF THE INTERIOR

U.S. GEOLOGICAL SURVEY

${ }^{1}$ Sequim, Washington 


\section{Nabesna quadrangle}

Descriptions of the mineral occurrences shown on the accompanying figure follow. See U.S. Geological Survey (1996) for a description of the information content of each field in the records. The data presented here are maintained as part of a statewide database on mines, prospects and mineral occurrences throughout Alaska.

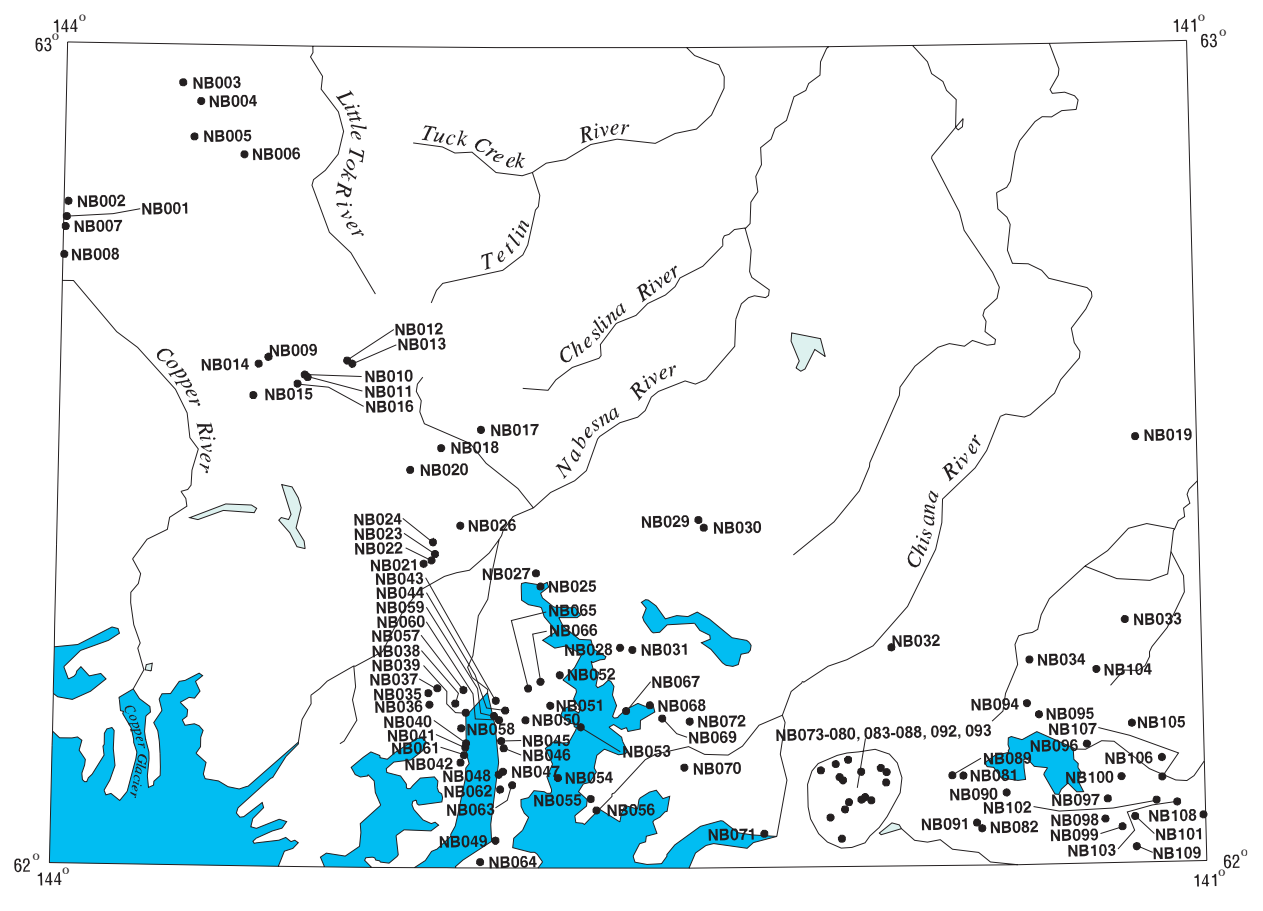

Distribution of mineral occurrences in the Nabesna 1:250,000-scale quadrangle, Alaska

This and related reports are accessible through the USGS World Wide Web site http://ardf.wr.usgs.gov. Comments or information regarding corrections or missing data, or requests for digital retrievals should be directed to: Frederic Wilson, USGS, 4200 University Dr., Anchorage, AK 99508-4667, e-mail fwilson@usgs.gov, telephone (907) 786-7448. This compilation is authored by:

Travis L. Hudson Sequim, WA

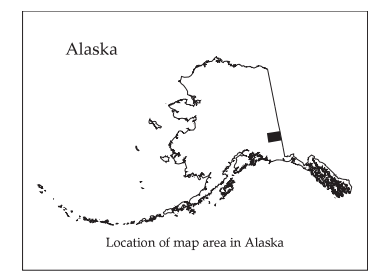

This report is preliminary and has not been reviewed for conformity with U.S. Geological Survey editorial standards or with the North American Stratigraphic code. Any use of trade, product, or firm names is for descriptive purposes only and does not imply endorsement by the U.S. Government. 


\section{Site name(s): Slope Creek}

Site type: Mine

ARDF no.: NB001

Latitude: 62.7879

Quadrangle: NB D-6

Longitude: 143.9914

\section{Location description and accuracy:}

This placer mine is on Slope Creek, a west tributary to Porcupine Creek. It is at an elevation of about 3,600 feet, about 1.1 miles upstream from Porcupine Creek. It is close to the west boundary of the Nabesna D-6 quadrangle in the SW1/4 of section 30, T. 12 N., R. 8 E. of the Copper River Meridian. This is locality 58 of Richter and others (1975). Slope Creek is not named on the USGS Nabesna D-6 quadrangle (revised 1969) but it is clearly located by Richter (1966) and Richter and Matson (1968). This mine was included by Cobb and Richter (1980) under the name 'Slope Cr.'. The map location is accurate to within a few hundred feet. Note that Richter (1964) identified Slope Creek as Boulder Creek, and Cobb and Richter (1980) note that confusion exists between these two nearby creeks in several early reports. Richter's (1966) location for Slope Creek is followed in this record.

\section{Commodities:}

Main: $\mathrm{Au}$

Other: $\mathrm{Ag}, \mathrm{Bi}, \mathrm{Cu}$

Ore minerals: Gold, magnetite, native copper, silver, unidentified bismuth mineral

\section{Gangue minerals:}

\section{Geologic description:}

A small amount of gold was recovered from this placer mine on upper Slope Creek. The gold is fine, rough, and accompanied by wire silver, native copper, a bismuth mineral, and magnetite (Moffit, 1944; 1954). Bedrock in Slope Creek is dominantly andesitic volcanic rocks of the upper Paleozoic Tetelna Volcanics (Richter, 1976) but felsic plutonic rocks of the Ahtell pluton are exposed about 1 mile to the west. The andesitic rocks are cut by an east-west trending fault at the head of Slope Creek (Richter, 1966, figure 2).

\section{Alteration:}

Age of mineralization:

Holocene. 


\section{Deposit model:}

Placer Au (Cox and Singer, 1986; model 39a)

Deposit model number (After Cox and Singer, 1986 or Bliss, 1992):

$39 \mathrm{a}$

Production Status: Yes; small

Site Status: Inactive

Workings/exploration:

Small-scale surface placer workings are present.

\section{Production notes:}

Production was probably less than 500 ounces (Cobb and Richter, 1980).

\section{Reserves:}

\section{Additional comments:}

\section{References:}

Moffit, 1944; Moffit, 1954; Richter, 1964; Richter, 1966; Richter, 1976; Richter and Matson, 1968; Richter and others, 1975; Cobb and Richter, 1980.

Primary reference: Moffit, 1944

Reporter(s): Travis L. Hudson (Applied Geology)

Last report date: $11 / 24 / 02$ 


\section{Site name(s): Unnamed (southwest of Indian Pass Lake)}

Site type: Occurrence

ARDF no.: NB002

Latitude: 62.8065

Quadrangle: NB D-6

Longitude: 143.9880

\section{Location description and accuracy:}

This occurrence is on a ridge between two unnamed west tributaries of Porcupine Creek. It is close to a saddle at an elevation of about 4,700 feet, about 1.1 miles west of the Eagle trail, in the SW1/4 of section 19, T. 12 N., R. 8 E. of the Copper River Meridian. This is locality 1 of Richter and others (1975). It is located to within several hundred feet. Cobb and Richter (1980) included this occurrence under the name 'Indian Pass Lake'.

\section{Commodities:}

Main: $\mathrm{Au}$

Other:

Ore minerals: Gold, pyrite

Gangue minerals: Quartz

\section{Geologic description:}

Disseminated pyrite and small quartz-pyrite veins occur in a small hornblende diorite stock that intrudes late Paleozoic andesitic rocks of the Tetelna Volcanics (Richter, 1966, 1976; Richter and others, 1975). A sample of hornblende diorite with minor disseminated pyrite from this locality contained 0.3 part per million gold (sample R60, Richter and Matson, 1968). Plutonic rocks in this area are part of a Pennsylvanian magmatic suite that varies from gabbro to granite and has U-Pb zircon ages between 290 and $320 \mathrm{Ma}$ (Richter, Lanphere, and Matson, 1975; Miller, 1994, p. 541-542).

\section{Alteration:}

Oxidation; pyrite-bearing rocks in this area are commonly limonite-stained (Richter, 1966).

\section{Age of mineralization:}

Probably Pennsylvanian, the age of plutonic rocks in the area.

\section{Deposit model:}


Polymetallic veins and/or porphyry $\mathrm{Cu}-\mathrm{Au}$ (Cox and Singer, 1986; models 22c and 20c)

Deposit model number (After Cox and Singer, 1986 or Bliss, 1992):

$22 \mathrm{c} ; 20 \mathrm{c}$

Production Status: No

Site Status: Inactive

Workings/exploration:

Production notes:

Reserves:

Additional comments:

References:

Richter, 1966; Richter and Matson, 1968; Richter and others, 1975; Richter, Lanphere, and Matson, 1975; Richter, 1976; Cobb and Richter, 1980; Miller, 1994.

Primary reference: Richter and Matson, 1968

Reporter(s): Travis L. Hudson (Applied Geology)

Last report date: $11 / 24 / 02$ 


\section{Site name(s): Corky; Roseie; Ram's Horn; Verde}

Site type: Prospect

ARDF no.: NB003

Latitude: 62.9536

Quadrangle: NB D-6

Longitude: 143.6877

\section{Location description and accuracy:}

This prospect is on the ridge west of lower Stratton Creek. It is at an elevation of about 4,000 feet, 3,500 feet west of Stratton Creek in the NW1/4 of section 34, T. 14 N., R. 9 E. of the Copper River Meridian. It is approximately located, perhaps to within several thousand feet.

\section{Commodities:}

Main: Asbestos

\section{Other:}

Ore minerals: Asbestos

Gangue minerals: Serpentine

\section{Geologic description:}

A thin belt of serpentinite extends west-northwest from near Stratton Creek to north of Mentasta Lake (Richter, 1967, 1976). Mining claims for asbestos have been located near the east end of this belt (U. S. Bureau of Mines, 1995; Kardex location MILS 0020780090). The serpentinite locally contains rodingite inclusions with thin nephritic rims and lenses of magnesite-dolomite-silica rock (Richter, 1976). This alpine-type ultramafic body is within Devonian metasedimentary rocks and is considered to be Cretaceous (Richter, 1976).

\section{Alteration:}

Serpentinization; magnesite-dolomite-silica replacement.

\section{Age of mineralization:}

The inferred age of the serpentine body is Cretaceous (Richter, 1976).

\section{Deposit model:}

Serpentine-hosted asbestos (Cox and Singer, 1986; model 8d)

Deposit model number (After Cox and Singer, 1986 or Bliss, 1992): 
$8 d$

Production Status: None

Site Status: Probably inactive

Workings/exploration:

There are no known workings but some surface prospecting has probably occurred.

Production notes:

Reserves:

Additional comments:

References:

Richter, 1967; Richter, 1976; U. S. Bureau of Mines, 1995.

Primary reference: Richter, 1976

Reporter(s): Travis L. Hudson (Applied Geology)

Last report date: $11 / 24 / 02$ 


\section{Site name(s): Patten}

Site type: Prospect

ARDF no.: NB004

Latitude: 62.9312

Quadrangle: NB D-6

Longitude: 143.6386

\section{Location description and accuracy:}

This prospect is 1,000 feet north of the Mentasta Lake road and 2,100 feet northwest of the intersection of this road with the Glen Highway. It is at an elevation of about 2,700 feet in the SE1/4 of section 2, T. 13 N., R. 9 E. of the Copper River Meridian. It is locality 7 of Richter (1967) and locality 2 of Richter and others (1975). It is located to within a few hundred feet.

\section{Commodities:}

Main: Jade

\section{Other:}

Ore minerals: Nephrite

Gangue minerals: Chlorite, serpentine

\section{Geologic description:}

A thin band of serpentinite in Devonian metasedimentary rocks was prospected for asbestos in the 1950s by L. L. Patten (Richter, 1967). A dense, slightly schistose, and hard rock from one of the prospect pits was found to contain nephrite (jade). The nephrite is associated with roddingite inclusions and ranges in color from dark to light green with some apple-green zones. The deposit has produced a number of pounds of semiprecious stone (Richter and others, 1975). The alpine-type ultramafic body that hosts the deposit is Cretaceous (Richter, 1976).

\section{Alteration:}

Serpentinization.

\section{Age of mineralization:}

The serpentinite body that hosts the deposit is inferred to be Cretaceous (Richter, 1976).

\section{Deposit model:}

Serpentine-hosted asbestos (Cox and Singer, 1986; model 8d) 
Deposit model number (After Cox and Singer, 1986 or Bliss, 1992):

$8 d$

Production Status: Undetermined.

Site Status: Probably inactive

Workings/exploration:

Several small prospecting pits have been dug on this deposit.

Production notes:

The deposit produced a number of pounds of jadeite over 10 years before 1975 (Richter and others, 1975).

\section{Reserves:}

Additional comments:

References:

Richter, 1967; Richter and others, 1975; Richter, 1976.

Primary reference: Richter, 1967

Reporter(s): Travis L. Hudson (Applied Geology)

Last report date: 11/24/02 


\section{Site name(s): Unnamed (east of Mentasta Lake)}

Site type: Occurrence

ARDF no.: NB005

Latitude: 62.8878

Quadrangle: NB D-6

Longitude: 143.6552

\section{Location description and accuracy:}

This occurrence is 3,500 feet east of the Mentasta Lodge on the Glenn Highway. It is at an elevation of about 3,000 feet in the SW1/4 of section 23, T. 13 N., R. 9 E. of the Copper River Meridian. This is locality 7 of Richter (1967) and locality 3 of Richter and others (1975). The location is accurate within a few hundred feet.

\section{Commodities:}

Main: $\mathrm{Ag}, \mathrm{Cu}$

\section{Other:}

Ore minerals: Bornite, chalcopyrite

Gangue minerals: Calcite, epidote

\section{Geologic description:}

Bornite and minor chalcopyrite fill vesicles and form irregular segregations disseminated through a 400-foot-thick section of Triassic, Nikolai Greenstone (Richter, 1967, 1976). The host metabasalt is highly epidotized and locally cut by veinlets of red jasper. The bornite is associated with calcite and epidote. A grab sample containing copper minerals assayed 1.1 percent copper, 0.02 ounce of gold per ton, and 0.02 ounce of silver per ton (Richter, 1967). Alteration and copper mineralization in Nikolai Greenstone is thought to have accompanied regional deformation and low-grade metamorphism in the Late Jurassic to Early Cretaceous (MacKevett and others, 1997).

\section{Alteration:}

Epidotization.

\section{Age of mineralization:}

Cretaceous? Alteration and copper mineralization in the Nikolai Greenstone is thought to have accompanied regional deformation and low-grade metamorphism in the Late Jurassic to Early Cretaceous (MacKevett and others, 1997).

\section{Deposit model:}


Basaltic copper (Cox and Singer, 1986; model 23)

Deposit model number (After Cox and Singer, 1986 or Bliss, 1992): 23

Production Status: None

Site Status: Inactive

Workings/exploration:

There are no known workings but some surface prospecting has probably occurred.

Production notes:

Reserves:

Additional comments:

References:

Richter, 1967; Richter and others, 1975; Richter, 1976; MacKevett and others, 1997.

Primary reference: Richter, 1967

Reporter(s): Travis L. Hudson (Applied Geology)

Last report date: $11 / 24 / 02$ 


\section{Site name(s): Unnamed (north of Bear Valley)}

Site type: Occurrence

ARDF no.: NB006

Latitude: 62.8671

Quadrangle: NB D-6

Longitude: 143.5210

\section{Location description and accuracy:}

This occurrence is on the crest of the range north of Bear Valley. It is in a saddle at an elevation of 5,450 feet, about 6,500 feet southeast of elevation 5870. The site is just inside the west boundary of NE1/4 of section 33, T. 13 N., R. 10 E. of the Copper River Meridian. This is locality 4 of Richter and others (1975). Cobb and Richter (1980) included this deposit as an 'Unnamed occurrence'. It is located to within a few hundred feet.

\section{Commodities:}

Main: $\mathrm{Cu}$

Other:

Ore minerals: Azurite, malachite

\section{Gangue minerals:}

\section{Geologic description:}

Amygdaloidal basalt of the Triassic, Nikolai Greenstone is heavily stained with azurite and malachite at this location. Copper mineralization is locally common in Nikolai Greenstone and is thought to have accompanied regional deformation and low-grade metamorphism in the Late Jurassic to Early Cretaceous (MacKevett and others, 1997).

\section{Alteration:}

Age of mineralization:

Cretaceous? Alteration and copper mineralization in the Nikolai Greenstone is thought to have accompanied regional deformation and low-grade metamorphism in the Late Jurassic to Early Cretaceous (MacKevett and others, 1997).

\section{Deposit model:}

Basaltic copper (Cox and Singer, 1986; model 23)

Deposit model number (After Cox and Singer, 1986 or Bliss, 1992): 
23

Production Status: None

Site Status: Inactive

Workings/exploration:

Production notes:

Reserves:

Additional comments:

References:

Richter and others, 1975; Cobb and Richter, 1980; MacKevett and others, 1997.

Primary reference: Richter and others, 1975

Reporter(s): Travis L. Hudson (Applied Geology)

Last report date: $11 / 24 / 02$ 


\section{Site name(s): Boulder Creek}

Site type: Mine

ARDF no.: NB007

Latitude: 62.7757

Quadrangle: NB D-6

Longitude: 143.9941

\section{Location description and accuracy:}

This placer mine is in the headwaters of Boulder Creek, a west tributary to Porcupine Creek. It is an elevation of about 3,400 feet, about 5,500 feet upstream from Porcupine Creek in the SW1/4 of section 31, T. 12 N., R. 8 E. of the Copper River Meridian. Boulder Creek is not named on the USGS Nabesna D-6 quadrangle (revised 1969), but it is identified by Richter (1966) as a west tributary to Porcupine Creek, south of Slope Creek (NB001).

Richter (1964) identified Slope Creek as Boulder Creek and Cobb and Richter (1980) note that confusion between these two nearby creeks exists in several early reports. Richter's (1966) location for these creeks is followed in this records. The location shown by Richter (1966, figure 5) is just inside the Gulkana quadrangle. This is locality 59 of Richter and others (1975) who show it to be just inside the Nabesna quadrangle. The location provided by Richter and others (1975) is followed in this record and is accurate within several hundred feet. Cobb and Richter (1980) include this mine under the name 'Boulder Ck.'.

\section{Commodities:}

Main: $\mathrm{Au}$

Other: $\mathrm{Ag}, \mathrm{Bi}, \mathrm{Cu}$

Ore minerals: Copper, gold, silver, unidentified bismuth mineral

\section{Gangue minerals:}

\section{Geologic description:}

Richter (1966) and Richter and others (1975) show placer gold workings on this west tributary to Porcupine Creek. At least some of the recovered gold was coarse and smooth, but if this deposit is similar to other gold placers in the area, some of the gold may have been rough, wiry,or dendritic and it may have been associated with wiry native silver, native copper, and an unidentified bismuth mineral (Moffit, 1954; Richter, 1964; 1966). Bedrock in Boulder Creek is dominantly andesitic volcanic rocks of the upper Paleozoic, Tetelna Volcanics, but felsic plutonic rocks of the Ahtell pluton are exposed about 1 mile to the west (Richter, 1966; 1976). 


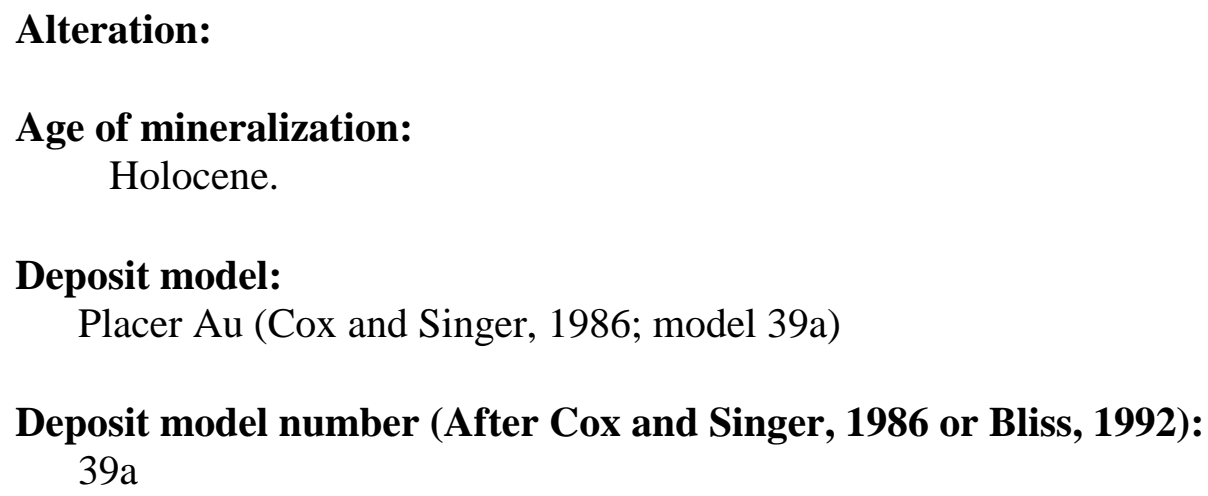

Alteration:

Age of mineralization:

Holocene.

Deposit model:

Placer Au (Cox and Singer, 1986; model 39a)

Deposit model number (After Cox and Singer, 1986 or Bliss, 1992):

$39 \mathrm{a}$

Production Status: Yes; small

Site Status: Inactive

Workings/exploration:

Small-scale surface placer workings are present.

Production notes:

Reserves:

Additional comments:

References:

Moffit, 1954; Richter, 1964; Richter, 1966; Richter and others, 1975; Richter, 1976;

Cobb and Richter, 1980.

Primary reference: Richter, 1966

Reporter(s): Travis L. Hudson (Applied Geology)

Last report date: $11 / 24 / 02$ 


\section{Site name(s): Willow Creek}

Site type: Mine

ARDF no.: NB008

Latitude: 62.7417

Quadrangle: NB C-6

Longitude: 143.9959

\section{Location description and accuracy:}

This placer mine is on Willow Creek, a north tributary to lower Ahtell Creek. It is at an elevation of about 2,700 feet, about 0.9 mile upstream of the junction of Ahtell Creek. The site is very close to the northeast corner of the Nabesna C-6 quadrangle. This is locality 60 of Richter and others (1975). It is located to within a few hundred feet. Cobb and Richter (1980) included this mine under the name 'Willow Cr.'.

\section{Commodities:}

Main: $\mathrm{Au}$

\section{Other:}

Ore minerals: Copper, gold, silver

\section{Gangue minerals:}

\section{Geologic description:}

A small placer gold mine on Willow Creek was apparently worked and abandoned in the 1930s (Richter, 1964). If this deposit is similar to other gold placers in the area, the gold is probably rough, wiry, or dendritic and it may have been associated with wiry native silver and native copper (Moffit, 1954; Richter, 1964; 1966). Bedrock in Willow Creek is dominantly andesitic volcanic rocks of the upper Paleozoic, Tetelna Volcanics but felsic plutonic rocks of the Ahtell pluton are exposed about 2 miles to the west (Richter, 1966; 1976).

\section{Alteration:}

Age of mineralization:

Holocene.

\section{Deposit model:}

Placer Au (Cox and Singer, 1986; model 39a)

Deposit model number (After Cox and Singer, 1986 or Bliss, 1992): 
$39 \mathrm{a}$

Production Status: Yes; small

Site Status: Inactive

Workings/exploration:

Small-scale surface placer workings are present.

Production notes:

Reserves:

Additional comments:

References:

Moffit, 1954; Richter, 1964; Richter, 1966; Richter and others, 1975; Richter, 1976; Cobb and Richter, 1980.

Primary reference: Richter, 1964

Reporter(s): Travis L. Hudson (Applied Geology)

Last report date: $11 / 24 / 02$ 


\section{Site name(s): Unnamed (northwest head of Caribou Creek)}

Site type: Prospect

ARDF no.: NB009

Latitude: 62.6208

Quadrangle: NB C-5

Longitude: 143.4497

\section{Location description and accuracy:}

This prospect is in the headwaters of an unnamed north tributary to Caribou Creek. It is an an elevation of about 4,800 feet, 3,200 feet northwest of elevation 5620, and 3,000 feet south-southeast of elevation 6240. The site is in the NE1/4 of section 25, T. $10 \mathrm{~N}$., R.10 E. of the Copper River Meridian. This is locality 1 of Richter and Schmoll (1973), locality 5 of Richter and others (1975), and National Park Service locality WRST-2 (unpublished data). It is located to within a few hundred feet.

\section{Commodities:}

Main: $\mathrm{Au}, \mathrm{Pb}, \mathrm{Zn}$

\section{Other:}

Ore minerals: Galena, gold, pyrite, sphalerite

Gangue minerals: Calcite, quartz

\section{Geologic description:}

Gold occurs in 1/4- to 2 -inch-thick stringers of quartz, calcite, pyrite, galena, and sphalerite that are localized in a zone 6 to 12 inches wide that cuts dioritized volcanic rocks. An adit was driven N $65 \mathrm{E}$ to crosscut the zone which is near an 8-foot-wide trachyte dike that strikes N $55 \mathrm{~W}$ and dips $45 \mathrm{NE}$ (Moffit, 1954). The volcanic rocks are part of the Pennsylvanian-Permian Tetelna Volcanics that are intruded by a diorite gneiss complex within 500 feet of the prospect (Matson and Richter, 1971 [OFR 71-204]; Richter and Schmoll, 1973; Richter, 1976). K/Ar ages from the diorite complex indicate that it is Early Jurassic or older (Richter. Lanphere, and Matson, 1975).

\section{Alteration:}

\section{Age of mineralization:}

Early Jurassic or younger? This prospect is in the border zone of a large diorite complex that is Early Jurassic or older (Richter, Lanphere, and Matson, 1975).

\section{Deposit model:}


Polymetallic veins (Cox and Singer, 1986; model 22c)

Deposit model number (After Cox and Singer, 1986 or Bliss, 1992):

$22 \mathrm{c}$

Production Status: Undetermined.

Site Status: Inactive

Workings/exploration:

An adit was driven $\mathrm{N} 65 \mathrm{E}$ to crosscut the mineralized zone. It was caved by the early 1950s (Moffit, 1954).

Production notes:

Reserves:

Additional comments:

The prospect is in the Wrangell-St. Elias National Preserve.

\section{References:}

Moffit, 1954; Matson and Richter, 1971 (OFR 71-204); Richter and Schmoll, 1973; Richter and others, 1975; Richter, Lanphere, and Matson, 1975.

Primary reference: Moffit, 1954

Reporter(s): Travis L. Hudson (Applied Geology)

Last report date: $11 / 24 / 02$ 


\section{Site name(s): Rock Creek (Molybdenum)}

Site type: Prospect

ARDF no.: NB010

Latitude: 62.5996

Quadrangle: NB C-5

Longitude: 143.3533

\section{Location description and accuracy:}

This prospect is on the ridge between Rock Creek and Little Jack Creek. It is at an elevation of about 5,300 feet, 1,800 feet southwest of peak 6315, and 4,000 feet southeast of saddle 5310. The site is near the center of the south boundary of section 33, T. 10 N., R. 11 E. of the Copper River Meridian. This is locality 4 of Richter and Schmoll (1973), locality 6 of Richter and others (1975), and National Park Service locality WRST-5 (unpublished data). Cobb and Richter (1980) included this prospect under the name 'Rock Cr.'. It is located to within a few hundred feet.

\section{Commodities:}

Main: Mo

\section{Other:}

Ore minerals: Molybdenite

\section{Gangue minerals:}

\section{Geologic description:}

Books of molybdenite up to 1.5 inches in diameter occur in a pegmatite dike that cuts alkali gneiss. High grade samples were reported to average about 3 percent molybdenum (Smith, 1939). The pegmatite dike strikes N $20 \mathrm{~W}$, dips $60 \mathrm{SW}$, ranges from a few inches to 2 feet in thickness and can be traced for 70 feet on the surface. Some molybdenite occurs as flakes, blebs, and veinlets disseminated in finer grained parts of the alkali gneiss (Moffit, 1943, 1954). The gneiss intrudes metavolcanic rocks of the upper Paleozoic, Tetelna Volcanics (Richter and Schmoll, 1973; Richter, 1976).

This deposit was staked in 1936 and explored by open cuts; soon after. Kennecott Copper Corporation drove a 160-foot-long adit under the exposed mineralization in 1937. They did not find molybdenite in the adit and further exploration has been restricted to surface observations and sampling.

\section{Alteration:}

Age of mineralization: 
Early Jurassic or older; K/Ar ages indicate an Early Jurassic or older age for the host intrusive complex (Richter and others, 1975).

Deposit model:

Molybdenum in pegmatite dike

Deposit model number (After Cox and Singer, 1986 or Bliss, 1992):

Production Status: None

Site Status: Inactive

\section{Workings/exploration:}

This deposit was staked in 1936 and explored by open cuts; soon after. Kennecott Copper Corporation drove a 160-foot-long adit under the exposed mineralization in 1937. They did not find molybdenite in the adit and further exploration has been restricted to surface observations and sampling.

\section{Production notes:}

\section{Reserves:}

\section{Additional comments:}

The prospect is in the Wrangell-St. Elias National Preserve.

\section{References:}

Smith, 1939; Moffit, 1943; Moffit, 1954; Richter and Schmoll, 1973; Richter and others, 1975; Richter, Lanphere, and Matson, 1975; Richter, 1976; Cobb and Richter, 1980.

Primary reference: Moffit, 1943

Reporter(s): Travis L. Hudson (Applied Geology)

Last report date: $11 / 24 / 02$ 


\section{Site name(s): Rock Creek (Corundum)}

Site type: Prospect

ARDF no.: NB011

Latitude: 62.5966

Quadrangle: NB C-5

Longitude: 143.3456

\section{Location description and accuracy:}

This prospect is on the ridge between Rock Creek and Little Jack Creek. It is at an elevation of about 5,500 feet, 2,000 feet south-southwest of peak 6315, and 4,000 feet northnortheast of peak 5270. The site is close to the center of the north boundary of section 4 , T. 9 N., R. 11 E. of the Copper River Meridian. This is locality 5 of Richter and Schmoll (1973), locality 7 of Richter and others (1975), and National Park Service locality WRST6 (unpublished data). Cobb and Richter (1980) included this prospect under the name 'Rock Cr.'. It is located to within a few hundred feet.

\section{Commodities:}

Main: Sapphire

Other:

Ore minerals: Corundum

\section{Gangue minerals:}

\section{Geologic description:}

Gray to blue-gray corundum occurs in aggregates associated with muscovite books in small and discontinuous alkali pegmatite dikes generally less than 3 feet wide. Some of the corundum crystals are up to $8 \mathrm{~cm}$ long but they commonly have a fractured habit and abundant feldspar inclusions (Richter, 1970; Richter and others, 1975). The host rock for the pegmatite dikes is peraluminous syenite-monzonite gneiss in a meta-igneous complex that has Early Jurassic K/Ar ages (Richter, Lanphere, and Matson, 1975).

\section{Alteration:}

Age of mineralization:

Early Jurassic K/Ar dates indicate an Early Jurassic or older age for the host intrusive complex (Richter. Lanphere, and Matson, 1975).

\section{Deposit model:}

Corundum in pegmatite dike 
Deposit model number (After Cox and Singer, 1986 or Bliss, 1992):

Production Status: Yes; small

Site Status: Inactive

Workings/exploration:

There has been some surface prospecting of this deposit.

Production notes:

Reserves:

Additional comments:

The prospect is in the Wrangell-St. Elias National Preserve.

\section{References:}

Richter, 1970; Richter and Schmoll, 1973; Richter and others, 1975; Richter, Lanphere, and Matson, 1975; Richter, 1976; Cobb and Richter, 1980.

Primary reference: Richter, 1970

Reporter(s): Travis L. Hudson (Applied Geology)

Last report date: $11 / 24 / 02$ 


\section{Site name(s): Trail Creek}

Site type: Prospect

ARDF no.: NB012

Latitude: 62.6174

Quadrangle: NB C-5

Longitude: 143.2414

\section{Location description and accuracy:}

This placer prospect is in the valley of an unnamed, east headwater tributary to Trail Creek. It is at an elevation of about 4,800 feet, 6,000 feet northwest of peak 7080, and 5,000 feet southwest of elevation 6285. The prospect is about 0.4 mile west of the center of section 30, T. 10 N., R. 12 E. of the Copper River Meridian. This is locality 3 of Richter and Schmoll (1973), locality 61 of Richter and others (1975), and National Park Service locality WRST-7 (unpublished data). This prospect was included by Cobb and Richter (1980) under the name 'Trail Cr.'. It is located to within a few hundred feet.

\section{Commodities:}

Main: $\mathrm{Au}$

\section{Other:}

Ore minerals: Gold

\section{Gangue minerals:}

\section{Geologic description:}

Placer gold claims were staked at this locality in 1931 and subsequently prospected without encouraging results (Moffit, 1943). Some surface placer workings are present (Richter and others, 1975). Bedrock in this tributary to Trail Creek includes abundant Upper Jurassic argillite in its headwaters and Triassic limestone and greenstone downstream. Fine-grained dioritic dikes and irregular intrusions are widespread in the bedrock of this drainage (Richter and Schmoll, 1973 ).

\section{Alteration:}

Age of mineralization:

Quaternary.

\section{Deposit model:}

Placer Au (Cox and Singer, 1986; model 39a) 
Deposit model number (After Cox and Singer, 1986 or Bliss, 1992):

$39 \mathrm{a}$

Production Status: Undetermined.

Site Status: Inactive

Workings/exploration:

Some surface placer workings are present (Richter and others, 1975).

Production notes:

Reserves:

Additional comments:

The prospect is in the Wrangell-St. Elias National Preserve.

\section{References:}

Moffit, 1943; Richter and Schmoll, 1973; Richter and others, 1975; Cobb and Richter, 1980.

Primary reference: Moffit, 1943

Reporter(s): Travis L. Hudson (Applied Geology)

Last report date: $11 / 24 / 02$ 


\section{Site name(s): Unnamed (east of upper Trail Creek)}

Site type: Occurrence

ARDF no.: NB013

Latitude: 62.6135

Quadrangle: NB C-5

Longitude: 143.2277

\section{Location description and accuracy:}

This occurrence is on a high ridge east of upper Trail Creek. It is at an elevation of about 6,000 feet, 3,600 feet northwest of peak 7080 and 5,800 feet east of Trail Creek. The occurrence is about 0.3 mile south-southwest of the center of section 30, T. 10 N., R. 12 E. of the Copper River Meridian. This is locality 2 of Richter and Schmoll (1973), locality 8 of Richter and others (1975), and National Park Service locality WRST-8 (unpublished data). Cobb and Richter (1980) included this locality as an 'Unnamed' occurrence'. It is located to within a few hundred feet.

\section{Commodities:}

Main: $\mathrm{Ag}, \mathrm{Pb}, \mathrm{Zn}$

Other:

Ore minerals: Galena, sphalerite, tetrahedrite

Gangue minerals: Carbonate minerals, quartz

\section{Geologic description:}

Small quartz-carbonate veins that contain galena, sphalerite, and tetrahedrite occur in the border zone of a small diorite porphyry stock (Richter and others, 1975). The diorite porphyry stock, part of a Cretaceous or Tertiary intrusive suite, intrudes Triassic limestone at this locality.

\section{Alteration:}

\section{Age of mineralization:}

Cretaceous or Tertiary. The host diorite porphyry is part of an intrusive suite that cuts rocks as young as Jurassic or Cretaceous in the headwaters of Trail Creek (Richter and Schmoll, 1973; Richter, 1976).

\section{Deposit model:}

Polymetallic veins (Cox and Singer, 1986; model 22c) 
Deposit model number (After Cox and Singer, 1986 or Bliss, 1992):

$22 \mathrm{c}$

Production Status: None

Site Status: Inactive

Workings/exploration:

Only reconnaissance surface observations.

Production notes:

Reserves:

Additional comments:

The occurrence is in the Wrangell-St. Elias National Preserve.

\section{References:}

Richter and Schmoll, 1973; Richter and others, 1975; Richter, 1976; Cobb and Richter, 1980.

Primary reference: Richter and others, 1975

Reporter(s): Travis L. Hudson (Applied Geology)

Last report date: $11 / 24 / 02$ 


\section{Site name(s): Unnamed (north of upper Caribou Creek)}

Site type: Prospect

ARDF no.: NB014

Latitude: 62.6123

Quadrangle: NB C-5

Longitude: 143.4757

\section{Location description and accuracy:}

This prospect is on the ridge between two, unnamed, north tributaries to Caribou Creek. It is at an elevation of about 4,500 feet, 1,300 feet north-northeast of peak 4702 and 5,100 feet west of elevation 5620 in the SE1/4 of section 26, T. 10 N., R 10 E., of the Copper River Meridian. This is National Park Service locality WRST-1 (unpublished data) and the coordinates for this prospect were provided by the National Park Service.

\section{Commodities:}

Main: $\mathrm{Au}$

\section{Other:}

Ore minerals: Gold

\section{Gangue minerals:}

\section{Geologic description:}

An unpublished National Park Service map and accompanying database identify this prospect. However, the reference for this prospect in the database (Moffit, 1943) does not describe a deposit in this area. A limonite-stained, northwest-trending steep fault cuts upper Paleozoic metavolcanic rocks near this prospect (Richter and Schmoll, 1973).

\section{Alteration:}

Oxidation: limonite-staining.

Age of mineralization:

\section{Deposit model:}

Deposit model number (After Cox and Singer, 1986 or Bliss, 1992):

Production Status: None

Site Status: Inactive 
Workings/exploration:

Production notes:

Reserves:

Additional comments:

The prospect is in the Wrangell-St. Elias National Preserve.

References:

Moffit, 1943; Richter and Schmoll, 1973.

Primary reference: This record

Reporter(s): Travis L. Hudson (Applied Geology)

Last report date: $11 / 24 / 02$ 


\section{Site name(s): Vicki}

Site type: Prospect

ARDF no.: NB015

Latitude: 62.5739

Quadrangle: NB C-5

Longitude: 143.4886

\section{Location description and accuracy:}

This prospect is on the north side of the Nabesna road about 2,000 feet west of Caribou Creek. The site is 0.2 mile south of the center of section 11, T. 9 N., R. 10 E. of the Copper River Meridian. This is National Park Service locality WRST-3 (unpublished data) and the coordinates for this prospect were provided by the National Park Service.

\section{Commodities:}

Main: $\mathrm{Au}$

\section{Other:}

Ore minerals: Gold

Gangue minerals:

\section{Geologic description:}

An unpublished National Park Service map and accompanying database identify this prospect. Two claims for placer gold were once staked at this locality (U.S. Bureau of Mines, 1994). The prospect is on the distal part of the alluvial fan of Caribou Creek (Richter and Schmoll, 1973).

\section{Alteration:}

Age of mineralization:

Quaternary.

\section{Deposit model:}

Placer Au (Cox and Singer, 1986; model 39a)

Deposit model number (After Cox and Singer, 1986 or Bliss, 1992):

$39 a$

Production Status: Undetermined. 
Site Status: Inactive

Workings/exploration:

Some surface prospecting has probably occurred at this locality.

Production notes:

\section{Reserves:}

Additional comments:

The prospect is in the Wrangell-St. Elias National Preserve.

\section{References:}

Richter and Schmoll, 1973; U. S. Bureau of Mines, 1994.

Primary reference: This record

Reporter(s): Travis L. Hudson (Applied Geology)

Last report date: $11 / 24 / 02$ 
Site name(s): Skyline

Site type: Prospect

ARDF no.: NB016

Latitude: 62.5886

Quadrangle: NB C-5

Longitude: 143.3721

Location description and accuracy:

This prospect is on the ridge west of upper Rock Creek. It is at an elevation of about 4,600 feet, 1,700 feet east of hill 4905 and 1,000 feet west of Rock Creek, about 0.5 mile east of the center of section 5, t. 9 N., R. 11 E. This is National Park Service locality WRST-4 (unpublished data) and the coordinates for this prospect were provided by the National Park Service.

\section{Commodities:}

Main: $\mathrm{Au}$

Other:

Ore minerals: Gold

Gangue minerals:

\section{Geologic description:}

An unpublished National Park Service map and accompanying database identify this prospect. Two claims for gold were once staked at this locality (U.S. Bureau of Mines, 1994). The prospect is near high-angle faults that cut upper Paleozoic metavolcanic rocks and a small area of limestone (Richter and Schmoll, 1973).

\section{Alteration:}

Age of mineralization:

\section{Deposit model:}

Deposit model number (After Cox and Singer, 1986 or Bliss, 1992):

Production Status: None

Site Status: Inactive 
Workings/exploration:

Some surface prospecting has probably occurred at this locality.

Production notes:

Reserves:

Additional comments:

The prospect is in the Wrangell-St. Elias National Preserve.

References:

Richter and Schmoll, 1973; U. S. Bureau of Mines, 1994.

Primary reference: This record

Reporter(s): Travis L. Hudson (Applied Geology)

Last report date: $11 / 24 / 02$ 


\section{Site name(s): Unnamed (southeast of Soda Lake)}

Site type: Occurrence

\section{ARDF no.: NB017}

Latitude: 62.5340

Quadrangle: NB C-4

Longitude: 142.8867

\section{Location description and accuracy:}

This occurrence is on the north-facing slopes, southeast of Soda Lake. It is at an elevation of about 4,500 feet, about 1,800 feet south-southeast of the east end of Soda Lake and 2,000 feet north of hill 5410. The site is just north of the center of section 25, T. 9 N., R. 13 E. of the Copper River Meridian. This is locality 10 of Richter and others (1975) and National Park Service locality WRST-11 (unpublished data). Cobb and Richter (1980) included this locality as an 'Unnamed occurrence'. It is located to within a few hundred feet.

\section{Commodities:}

Main: $\mathrm{Cu}$

Other:

Ore minerals: Native copper

\section{Gangue minerals:}

\section{Geologic description:}

Native copper occupies fractures in amygdaloidal basalt of the Triassic, Nikolai Greenstone (Richter and others, 1975, 1976; Richter, 1976). Copper mineralization is locally common in Nikolai Greenstone and is thought to have accompanied regional deformation and low-grade metamorphism in the Late Jurassic to Early Cretaceous (MacKevett and others, 1997).

\section{Alteration:}

\section{Age of mineralization:}

Cretaceous? Copper mineralization is locally common in Nikolai Greenstone and is thought to have accompanied regional deformation and low-grade metamorphism in the Late Jurassic to Early Cretaceous (MacKevett and others, 1997).

\section{Deposit model:}

Basaltic copper (Cox and Singer, 1986; model 23) 
Deposit model number (After Cox and Singer, 1986 or Bliss, 1992):

23

Production Status: None

Site Status: Inactive

Workings/exploration:

Production notes:

Reserves:

Additional comments:

The occurrence is in the Wrangell-St. Elias National Preserve.

\section{References:}

Richter and others, 1975; Richter and others, 1976; Richter, 1976; Cobb and Richter, 1980; MacKevett and others, 1997.

Primary reference: Richter and others, 1975

Reporter(s): Travis L. Hudson (Applied Geology)

Last report date: $11 / 24 / 02$ 
Site name(s): Bee Jay

Site type: Prospect

ARDF no.: NB018

Latitude: 62.5115

Quadrangle: NB C-4

Longitude: 142.9914

Location description and accuracy:

This prospect is on the north-facing slope south of Platinum Creek. It is at an elevation of about 4,000 feet, about 3,000 feet south of Platinum Creek. The prospect is in about the center of the SW1/4 of section 33, T. 9 N., R. 13 E. of the Copper River Meridian. This is National Park Service locality WRST-10 (unpublished data) and the coordinates for this prospect were provided by the National Park Service.

\section{Commodities:}

Main: $\mathrm{Ag}, \mathrm{Au}, \mathrm{Cu}, \mathrm{Pb}$

\section{Other:}

Ore minerals:

Gangue minerals:

\section{Geologic description:}

An unpublished National Park Service map and accompanying database identify this prospect. Claims were apparently once staked here for gold, silver, copper, and lead (U.S. Bureau of Mines, 1994). The prospect is in upper Paleozoic andesitic rocks of the Tetelna Volcanics (Richter and others, 1976).

\section{Alteration:}

Age of mineralization:

\section{Deposit model:}

Deposit model number (After Cox and Singer, 1986 or Bliss, 1992):

Production Status: None

Site Status: Inactive 
Workings/exploration:

Some surface prospecting may have occurred at this locality.

\section{Production notes:}

Reserves:

Additional comments:

The prospect is in the Wrangell-St. Elias National Preserve.

\section{References:}

Richter and others, 1976; U. S. Bureau of Mines, 1994.

Primary reference: This record

Reporter(s): Travis L. Hudson (Applied Geology)

Last report date: $11 / 24 / 02$ 


\section{Site name(s): Unnamed (south of Mirror Creek)}

Site type: Occurrence

ARDF no.: NB019

Latitude: 62.5193

Quadrangle: NB C-1

Longitude: 141.1609

\section{Location description and accuracy:}

This occurrence is in the high part of the uplands south of Mirror Creek. It is at an elevation of about 2,700 feet, about 500 feet north of elevation 2835. The occurrence is in the NE1/4 of section 31, T. 9 N., R. 23 E. of the Copper River Meridian. This is locality 57 of Richter and others (1975). It is located to within several hundred feet.

\section{Commodities:}

Main: $\mathrm{Cr}$

Other:

Ore minerals: Chromite

Gangue minerals:

\section{Geologic description:}

Cobble-sized float of massive chromite occurs at this locality (Richter and others, 1975). The chromite was eroded from a band of alpine-type ultramafic rocks that trends east-west for about 1 mile in this area (Richter, 1976).

\section{Alteration:}

Age of mineralization:

Cretaceous? This is the inferred age of the alpine-type ultramafic body (Richter, 1976).

Deposit model:

Podiform chromite (Cox and Singer, 1986; model 8b)

Deposit model number (After Cox and Singer, 1986 or Bliss, 1992): $8 b$

Production Status: None

Site Status: Inactive 
Workings/exploration:

Production notes:

Reserves:

Additional comments:

References:

Richter and others, 1975; Richter, 1976.

Primary reference: Richter and others, 1975

Reporter(s): Travis L. Hudson (Applied Geology)

Last report date: $11 / 24 / 02$ 


\section{Site name(s): Unnamed (lower Boyden Creek)}

Site type: Occurrence

ARDF no.: NB020

Latitude: 62.4847

Quadrangle: NB B-5

Longitude: 143.0726

\section{Location description and accuracy:}

This occurrence is on lower Boyden Creek. It is at an elevation of about 3,600 feet. 6,500 feet northwest of peak 5650. The occurrence is about 0.2 mile south of the center of section 7, T. 8 N., R. 13 E. of the Copper River Meridian. This is locality M1 of Lowe and others (1982), locality 9 of Richter and others (1975), and National Park Service locality WRST-9 (unpublished data). Cobb and Richter (1980) included this locality as an 'Unnamed occurrence'. It is located to within a few hundred feet.

\section{Commodities:}

Main: $\mathrm{Cu}$

\section{Other:}

Ore minerals: Chalcopyrite, pyrite

Gangue minerals: Quartz

\section{Geologic description:}

A quartz vein that contains pyrite and chalcopyrite is localized in a shear zone that cuts volcaniclastic rocks (Lowe and others, 1982). The shear zone is associated with a northwest-trending fault that cuts volcanic rocks of the upper Paleozoic Tetelna Volcanics. The fault cuts Tertiary basalt about 700 feet to the southeast of this occurrence (Lowe and others, 1982).

\section{Alteration:}

\section{Age of mineralization:}

Tertiary? The fault at this locality cuts Tertiary basalt about 700 feet to the southeast (Lowe and others, 1982).

\section{Deposit model:}

Polymetallic vein (Cox and Singer, 1986; model 22c)

Deposit model number (After Cox and Singer, 1986 or Bliss, 1992): 
$22 \mathrm{c}$

Production Status: None

Site Status: Inactive

Workings/exploration:

Production notes:

Reserves:

Additional comments:

The occurrence is in the Wrangell-St. Elias National Preserve.

\section{References:}

Richter and others, 1975; Cobb and Richter, 1980; Lowe and others, 1982.

Primary reference: Lowe and others, 1982

Reporter(s): Travis L. Hudson (Applied Geology)

Last report date: $11 / 24 / 02$ 


\section{Site name(s): Unnamed (southeast flank of White Mountain)}

Site type: Mine

ARDF no.: NB021

Latitude: 62.3704

Quadrangle: NB B-5

Longitude: 143.0353

\section{Location description and accuracy:}

This mine is low on southeast flank of White Mountain. It is at an elevation of about 3,750 feet, about 2,000 feet west-northwest of Nabesna. The map site is about 0.4 mile west of the center of section 21, T. 7 N., R. 13 E. of the Copper River Meridian. This is locality M4 of Lowe and others (1982), locality 14 of Richter and others (1975), and it is included in National Park Service locality WRST-14 (unpublished data). Cobb and Richter (1980) include this mine under the name 'Nabesna (Mining Corp.)'. It is located to within about 100 feet.

\section{Commodities:}

Main: $\mathrm{Ag}, \mathrm{Au}$

\section{Other:}

Ore minerals: Gold, limonite, pyrite

Gangue minerals: Quartz

\section{Geologic description:}

In the early 1900s, the Royal Development Co. found and briefly exploited a gossan zone developed over a gold-bearing sulfide deposit. The sulfide deposit is in a sheared intrusive rock and adjacent contact-metamorphosed limestone (Moffit and Knopf, 1909). Mining was in a surface cut where a 1- to 4-foot-wide mineralized zone was exposed. Pyrite is the dominant mineral in the deposit but if it is similar to others in the area (NB022), it probably also contains chalcopyrite, galena, and sphalerite A 16-inch-wide sample taken across the deposit assayed 0.06 ounce of gold per ton and 0.20 ounce silver per ton (Pilgrim, 1931, p. 60-61). A 3-stamp mill was erected in 1906; it processed about 60 tons of ore and reportedly recovered 0.6 ounce of gold per ton. Two adits totaling 130 feet in length were subsequently driven 200 feet below the gossan outcrop without encouraging results and the original claims were allowed to lapse in 1914. This mine is now included in the patented claim group surrounding the Nabesna mine (NB022).

Richter and others (1975) describe this deposit as a quartz diorite stock with disseminated pyrite and quartz-pyrite veins. They consider it to be a disseminated gold deposit. The deposit is in the contact zone of a mid-Cretaceous granodiorite and quartz diorite 
stock that intrudes Triassic limestone and dolomite (Lowe and others, 1982). Skarn assemblages are well developed in the general area (see NB022) and include calcic skarn with abundant garnet and pyroxene, and magnesian skarn with magnetite and serpentine (Weglarz, 1991; Newberry and others, 1997). Sulfide minerals are common in the calcic skarn and magnetite is common in the magnesian skarn. Chalcopyrite and other sulfide minerals are common in the calcic skarn and Newberry and others (1997) consider the deposits in the area to be gold-rich copper skarns. The gold-bearing sulfide-rich pods, lenses, and veins are commonly small bodies localized in marble-front replacements and crosscutting shears (Newberry and others, 1997, figure 9). A concordant biotite/ hornblende K/Ar date for the intrusive rocks in the area is 114 +/- 3.4 Ma (Richter, Lanphere, and Matson, 1975).

\section{Alteration:}

Oxidation. Calc-silicate and sulfide replacement.

\section{Age of mineralization:}

Mid-Cretaceous. A concordant biotite/hornblende K/Ar date for the intrusive rocks in the area is $114+/-3.4 \mathrm{Ma}$ (Richter, Lanphere, and Matson, 1975).

\section{Deposit model:}

Cu skarn (Cox and Singer, 1986; model 18b)

\section{Deposit model number (After Cox and Singer, 1986 or Bliss, 1992): $18 b$}

Production Status: Yes; small

Site Status: Inactive

\section{Workings/exploration:}

Mining was in a surface cut where a 1- to 4-foot-wide mineralized zone was exposed. A 3-stamp mill was erected in 1906; it processed about 60 tons that contained about 0.6 ounce of gold per ton. Two adits totaling 130 feet in length were subsequently driven 200 feet below the gossan outcrop without encouraging results and the original claims were allowed to lapse in 1914. This mine is now included in the patented claim group surrounding the Nabesna mine (NB022). Exploration including diamond drilling occurred during the 1980 s in the area.

\section{Production notes:}

\section{Reserves:}

Additional comments:

The mine is in the Wrangell-St. Elias National Preserve.

\section{References:}


Moffit and Knopf, 1909; Pilgrim, 1931; Wayland, 1943; Richter and others, 1975; Richter, Lanphere, and Matson, 1975; Cobb and Richter, 1980; Lowe and others, 1982;

Weglarz, 1991; Newberry and others, 1997.

Primary reference: Pilgrim, 1931

Reporter(s): Travis L. Hudson (Applied Geology)

Last report date: $11 / 24 / 02$ 


\section{Site name(s): Nabesna}

Site type: Mine

ARDF no.: NB022

Latitude: 62.3746

Quadrangle: NB B-5

Longitude: 143.0150

\section{Location description and accuracy:}

This mine is on the low, southeast flank of White Mountain at an elevation of about 3,600 feet, 1,000 feet north of Nabesna. The mine is about 0.1 mile northwest of the center of section 21, T. 7 N., R. 13 E. of the Copper River Meridian. This is locality M3 of Lowe and others (1982), locality 13 of Richter and others (1975), and National Park Service locality WRST-14 (unpublished data). Cobb and Richter included this mine under the name 'Nabesna (Mining Corp.)'. It is located to within about 100 feet.

\section{Commodities:}

Main: $\mathrm{Au}$

Other: $\mathrm{Ag}, \mathrm{Cu}, \mathrm{Fe}, \mathrm{Pb}, \mathrm{Zn}$

Ore minerals: Anglesite, arsenopyrite, cerussite, chalcopyrite, galena, gold, magnetite, pyrite, sphalerite, stibnite

Gangue minerals: Calcite, quartz

\section{Geologic description:}

Pyrite-rich ore bodies in tactite peripheral to a granitic stock were mined for their gold content at the Nabesna mine. The initial discovery was made in 1925 where a bear dug a hole that exposed the Bear vein that was to become the principal ore body in the mine (Wayland, 1943). A mill was in operation by 1931 and several ore bodies were developed over six levels of underground workings. There were 368 feet of surface cuts, 9,224 feet of drifts, and 6,209 feet of raises, in 650 vertical feet of mine workings (Wayland, 1943). Year-around operations were underway by 1935 when 60 tons per day were being milled. Most of the known ore bodies were mined out by 1939; total production was about 53,400 ounces of gold assuming a gold price of $\$ 35.00$ per ounce. This recovery was from 72,994 tons of ore that varied in grade from 0.46 to 2.58 ounces of gold per ton. The ore had a weighted average grade of 0.93 ounce of gold per ton; 15,228 tons of tailings had a weighted average grade of 0.39 ounce of gold per ton (Wayland, 1943, p. 194). The average recovery for the life of the mine was 73 percent. The ore concentrate was shipped to the Tacoma smelter and some copper and silver credits were obtained.

The gold-rich ore bodies were discontinuous sulfide veins and replacements along mar- 
ble-front contacts and crosscutting fissures (Wayland, 1943; Newberry and others, 1997). Pyrite was the most common sulfide but it was accompanied by lesser amounts of sphalerite, galena, and chalcopyrite, especially in upper parts of the mine. Arsenopyrite and stibnite were also reported and magnetite occurs locally at the margins or within some ore bodies. Sphalerite and galena occur in pockets and stringers cutting pyrite and along the edge of pyrite stringers, whereas chalcopyrite tends to be disseminated through the pyrite. Gold was with or near the later sulfides including chalcopyrite and galena. The principal gangue minerals are coarsely crystalline calcite and quartz. Oxidation extends a few tens of feet to as much as 350 feet below the surface; anglesite, cerussite, and a little sulfur were identified in oxidized portions of the veins (Pilgrim, 1931, p. 60-62; Wayland, 1943).

The individual ore bodies range in thickness from a few inches to 35 feet and average 5 to 7 feet thick. The Bear vein extends 320 feet horizontally, 250 feet vertically, and has a maximum thickness of 35 feet. The 'No. 49 stope' vein had a maximum horizontal length of 250 feet, a vertical length of 320 feet, and an average width of 4 to 5 feet. Other ore bodies were smaller irregular, pipelike, or tabular deposits. With the exception of the galena-rich 'No. 49 stope' vein, the ore bodies at lower levels had lower gold values, erratic mineralization, irregular shapes, and lesser amounts of sphalerite, chalcopyrite, and galena (Wayland, 1943). A five-foot sample across the Bear vein assayed 10.39 ounces of gold per ton 12.70 ounces of silver per ton, 1.67 percent lead, and 0.15 percent copper. A five-foot sample along the limestone/intrusive contact assayed 0.10 ounce gold per ton, 1.8 ounce silver per ton, and 4.2 percent copper (Pilgrim, 1931).

The deposits are in the contact zone of a mid-Cretaceous granodiorite and quartz diorite stock that intrudes Triassic limestone and dolomite (Lowe and others, 1982). Skarn assemblages are well developed in the general area and include calcic skarn with abundant garnet and pyroxene and magnesian skarn with magnetite and serpentine (Weglarz, 1991; Newberry and others, 1997). Minerals identified in the skarn assemblages include andradite, apatite, brookite, diopside-hedenbergite, calcite, chlorite, epidote, gypsum, magnetite, quartz, specular hematite, serpentine, spinel, sphene, vesuvianite, and wollastonite (Wayland, 1943). Massive magnetite bodies containing pyrite, calcite and a little gold are present at all levels of the mine and are up to 200 feet in maximum dimension; some are localized at marble contacts (Wayland, 1943; Weglarz, 1991; Newberry and others, 1997). Sulfide minerals are common in the calcic skarn and magnetite is common in the magnesian skarn. Chalcopyrite and other sulfide minerals are common in the calcic skarn and Newberry and others (1997) consider the deposits in the area to be gold-rich copper skarns. The gold-bearing sulfide-rich pods, lenses, and veins are commonly localized in marble-front replacements and crosscutting shears (Newberry and others, 1997, figure 9). A concordant biotite/hornblende $\mathrm{K} / \mathrm{Ar}$ date for nearby intrusive rocks is $114+/-3.4 \mathrm{Ma}$ (Richter, Lanphere, and Matson, 1975).

\section{Alteration:}

Oxidation was effective to a depth of several tens of feet and locally extends to more than 350 feet. Calc-silicate, magnetite, and sulfide replacement.

\section{Age of mineralization:}

Mid-Cretaceous. A concordant biotite/hornblende K/Ar date for the adjacent intrusive 
rocks is $114+/-3.4 \mathrm{Ma}$ (Richter, Lanphere, and Matson, 1975).

\section{Deposit model:}

Cu skarn (Cox and Singer, 1986; model 18b)

Deposit model number (After Cox and Singer, 1986 or Bliss, 1992):

$18 b$

Production Status: Yes; medium

Site Status: Inactive

\section{Workings/exploration:}

The initial discovery was made in 1925 where a bear dug by a bear exposed the Bear vein, the principal ore body in the mine (Wayland, 1943). A mill was in operation by 1931 and several deposits were developed over six levels of underground workings. An aerial tramway transported the ore to the mill. There were 368 feet of surface cuts, 9,224 feet of drifts, and 6,209 feet of raises in over 650 vertical feet of mine workings (Wayland, 1943, p. 192). A total of 9,999 feet of diamond drilling supported exploration and development of the mine. Year-around operations were underway by 1935 when 60 tons per day were being milled. Most of the known ore bodies were mined out by 1939 and the last recorded production was in 1940 (Wayland, 1943). Exploration of the Nabesna mine area took place several times in the last half of the 20th century but the results have not been made public.

\section{Production notes:}

Production is recorded from 1931 to 1940 . Assuming a gold price of $\$ 35.00$ per ounce, total production was about 53,400 ounces of gold. This was recovered from 72,994 tons of ore that ranged in grade from 0.46 to 2.58 ounces of gold per ton. The ore had a weighted average grade of 0.93 ounce of gold per ton; 15,228 tons of tailings had a weighted average grade of 0.39 ounce of gold per ton (Wayland, 1943, p. 194). The average recovery over the life of the mine was 73 percent. The ore concentrate was shipped to the Tacoma smelter and some copper and silver credits were obtained.

\section{Reserves:}

\section{Additional comments:}

The mine is in the Wrangell-St. Elias National Preserve.

\section{References:}

Pilgrim, 1931; Wayland, 1943; Richter and others, 1975; Richter, Lanphere, and Matson, 1975; Cobb and Richter, 1980; Lowe and others, 1982; Weglarz, 1991; Newberry and others, 1997.

Primary reference: Wayland, 1943 
Reporter(s): Travis L. Hudson (Applied Geology)

Last report date: 11/24/02 


\section{Site name(s): Rambler; Golden Eagle Group; Cliff vein}

Site type: Prospect

ARDF no.: NB023

Latitude: 62.3824

Quadrangle: NB B-5

Longitude: 143.0060

\section{Location description and accuracy:}

This prospect is low on the east flank of White Mountain. It is at an elevation of about 3,600 feet, 4,500 feet north-northeast of Nabesna. The site is in the SE1/4 of section 16, T. 7 N., R. 13 E. of the Copper River Meridian. This is locality M2 of Lowe and others (1982), locality 12 of Richter and others (1975), and National Park Service locality WRST-13 (unpublished data). Cobb and Richter (1980) included this prospect under the name 'Nabesna (Mining Corp.)'. It is located to within a few hundred feet.

\section{Commodities:}

Main: $\mathrm{Au}$

Other: $\mathrm{Cu}$

Ore minerals: Chalcopyrite, gold, marcasite, pyrite, pyrrhotite

\section{Gangue minerals:}

\section{Geologic description:}

A surface exposure of massive pyrrhotite with some pyrite and late marcasite was discovered at this prospect in 1940 (Wayland, 1943). The massive pyrrhotite was exposed over a length of 52 feet, a vertical distance of 34 feet, and a width of 19 feet. The pyrrhotite is coarse grained; some crystal are 2 inches in diameter. The pyrrhotite also forms crystals in vugs and Wayland (1943) observed minor chalcopyrite and late marcasite under the microscope. Wayland (1943) reported that 14 samples of the massive sulfide assayed as much as 2.43 ounces of gold per ton and averaged 0.92 ounce of gold per ton (assuming a gold price of $\$ 35.00$ per ounce).

The massive sulfide body replaces Triassic limestone peripheral to a mid-Cretaceous granodiorite and quartz diorite stock (Lowe and others, 1982). Skarn assemblages are exposed about 3,000 feet to the southwest at the Nabesna mine (NB022) where calcic skarn containing abundant garnet and pyroxene and magnesian skarn containing magnetite and serpentine are well developed (Weglarz, 1991; Newberry and others, 1997). Chalcopyrite and other sulfide minerals are common in the calcic skarn and Newberry and others (1997) consider the principal deposits in the area to be gold-rich copper skarns. A concordant biotite/hornblende K/Ar date for the intrusive rocks is $114+/-3.4$ Ma (Richter, 
Lanphere, and Matson, 1975).

\section{Alteration:}

Oxidation. Marcasite replacement of pyrrhotite.

\section{Age of mineralization:}

Mid-Cretaceous. A concordant biotite/hornblende K/Ar date for the intrusive rocks is 114 +/- 3.4 Ma (Richter, Lanphere, and Matson, 1975).

\section{Deposit model:}

Cu skarn (Cox and Singer, 1986; model 18b)

Deposit model number (After Cox and Singer, 1986 or Bliss, 1992):

$18 \mathrm{~b}$

Production Status: Undetermined.

Site Status: Inactive

\section{Workings/exploration:}

This deposit is exposed at the surface and has probably been explored by diamond drilling and and other techniques since its discovery in 1940 . It was an active prospect as recently as the 1980s (Lowe and others, 1982).

\section{Production notes:}

\section{Reserves:}

\section{Additional comments:}

The mine is in the Wrangell-St. Elias National Preserve.

\section{References:}

Wayland, 1943; Richter and others, 1975; Richter, Lanphere, and Matson, 1975; Cobb and Richter, 1980; Lowe and others, 1982; Weglarz, 1991; Newberry and others, 1997.

Primary reference: Wayland, 1943

Reporter(s): Travis L. Hudson (Applied Geology)

Last report date: $11 / 24 / 02$ 
Site name(s): Boyden B

Site type: Prospect

ARDF no.: NB024

Latitude: 62.3967

Quadrangle: NB B-5

Longitude: 143.0112

Location description and accuracy:

This prospect is near lower Skookum Creek about 6,500 feet northeast of White Mountain. The site is in the SE1/4 of section 9, T. 7 N., R. 13 E. of the Copper River Meridian. This is National Park Service locality WRST-12 (unpublished data) and the coordinates for this prospect were provided by the National Park Service.

\section{Commodities:}

Main: $\mathrm{Au}$

Other:

Ore minerals: Gold

Gangue minerals:

Geologic description:

An unpublished National Park Service map and accompanying database identify this gold prospect. It is located in an area of Quaternary deposits downstream from exposures of Triassic limestone and Nikolai Greenstone (Lowe and others, 1982). Gold-bearing sulfide bodies are present in Triassic carbonate rocks to the southwest of this prospect (NB021, NB022, and NB023).

\section{Alteration:}

Age of mineralization:

\section{Deposit model:}

Deposit model number (After Cox and Singer, 1986 or Bliss, 1992):

Production Status: None

Site Status: Inactive 
Workings/exploration:

Production notes:

Reserves:

Additional comments:

The prospect is in the Wrangell-St. Elias National Preserve.

\section{References:}

Lowe and others, 1982.

Primary reference: This record

Reporter(s): Travis L. Hudson (Applied Geology)

Last report date: $11 / 24 / 02$ 


\section{Site name(s): Camp Creek}

Site type: Occurrence

ARDF no.: NB025

Latitude: 62.3433

Quadrangle: NB B-4

Longitude: 142.7286

\section{Location description and accuracy:}

This occurrence is near the crest of the mountains between Cooper Creek and the Nabesna River. It is at an elevation of about 6,000 feet, 3,000 feet southwest of peak 7390 and 4,500 feet northwest of peak 7895. The occurrence is about 0.2 mile southeast of the center of section 36, T. 7 N., R. 14 E. of the Copper River Meridian. This is locality 15 of Richter and others (1975) and National Park Service locality WRST-18 (unpublished data). Cobb and Richter (1980) included this occurrence under the name 'Camp Cr.'. It is located to within a few hundred feet.

\section{Commodities:}

Main: $\mathrm{Cu}$

Other:

Ore minerals: Chalcocite

\section{Gangue minerals:}

\section{Geologic description:}

A chalcocite vein, 6 inches to 2 feet wide, cuts amygdaloidal basalt of the Triassic, Nikolai Greenstone here; a sample assayed 61 percent copper (Mendenhall and Schrader, 1903). Nikolai Greenstone makes up most of the bedrock in the headwaters of Camp Creek (Richter, 1971 [I-656], 1976). Copper mineralization is locally common in Nikolai Greenstone and is thought to have accompanied regional deformation and low-grade metamorphism in the Late Jurassic to Early Cretaceous (MacKevett and others, 1997).

\section{Alteration:}

Age of mineralization:

Cretaceous? Alteration and copper mineralization in the Nikolai Greenstone is thought to have accompanied regional deformation and low-grade metamorphism in the Late Jurassic to Early Cretaceous (MacKevett and others, 1997).

\section{Deposit model:}


Basaltic copper (Cox and Singer, 1986; model 23)

Deposit model number (After Cox and Singer, 1986 or Bliss, 1992): 23

Production Status: None

Site Status: Inactive

Workings/exploration:

Some surface prospecting has occurred at this locality.

Production notes:

Reserves:

Additional comments:

The occurrence is in the Wrangell-St. Elias National Preserve.

\section{References:}

Mendenhall and Schrader, 1903; Richter, 1971 (I-656); Richter and others, 1975; Richter, 1976; Cobb and Richter, 1980; MacKevett and others, 1997.

Primary reference: Mendenhall and Schrader, 1903

Reporter(s): Travis L. Hudson (Applied Geology)

Last report date: $11 / 24 / 02$ 


\section{Site name(s): Devils Mountain}

Site type: Occurrence

ARDF no.: NB026

Latitude: 62.4171

Quadrangle: NB B-4

Longitude: 142.9398

\section{Location description and accuracy:}

This occurrence is on the creek draining the northwest side of Devils Mountain. It is at an elevation of about 3,100 feet, about 6,000 feet southwest of the summit of Devil Mountain. This is locality 11 of Richter and others (1975) and National Park Service locality WRST-5 (unpublished data). It was included as an 'Unnamed occurrence' by Cobb and Richter (1980). It is located to within several hundred feet.

\section{Commodities:}

Main: $\mathrm{Cu}$

\section{Other:}

Ore minerals: Chalcopyrite, pyrrhotite

Gangue minerals: Actinolite, garnet

\section{Geologic description:}

Large boulders up to 6 feet or more in diameter of massive pyrrhotite, chalcopyrite, actinolite, and garnet occur at this locality (Richter and others, 1975). The source of these boulders is unknown. Quaternary deposits cover much of the lower areas of this drainage but a Cretaceous hornblende quartz diorite and diorite stock that intrudes upper Paleozoic metavolcanic rocks makes up most of the bedrock in the headwaters of the drainage (Richter, 1971 [I-656]; 1976).

\section{Alteration:}

Calc-silicate and sulfide replacement.

\section{Age of mineralization:}

Cretaceous? The parent deposit may be a skarn related to a hornblende quartz diorite and diorite stock in the headwaters of this drainage. This pluton is though to be midCretaceous in age like the Nabesna pluton several miles to the south (Richter, Lanphere, and Matson, 1975).

\section{Deposit model:}


Cu skarn (Cox and Singer, 1986; model 18b)

Deposit model number (After Cox and Singer, 1986 or Bliss, 1992):

$18 b$

Production Status: None

Site Status: Inactive

Workings/exploration:

The source of the mineralization has not been identified.

Production notes:

Reserves:

Additional comments:

The occurrence is in the Wrangell-St. Elias National Preserve.

\section{References:}

Richter, 1971 (I-656); Richter and others, 1975; Richter, Lanphere, and Matson, 1975; Richter, 1976; Cobb and Richter, 1980.

Primary reference: Richter and others, 1975

Reporter(s): Travis L. Hudson (Applied Geology)

Last report date: $11 / 24 / 02$ 


\section{Site name(s): Unnamed (upper Camp Creek)}

Site type: Prospect

ARDF no.: NB027

Latitude: 62.3593

Quadrangle: NB B-4

Longitude: 142.7407

\section{Location description and accuracy:}

This prospect is on upper Camp Creek, a south tributary to the Nabesna River. It is at an elevation of about 4,400 feet, 4,000 feet northwest of elevation 6690, and 4,000 feet northeast of elevation 6615 . The prospect is about 0.3 mile west of the center of section 25, T. 7 N., R. 14 E. of the Copper River Meridian. This is National Park Service locality WRST-17 (unpublished data) and the coordinates for this occurrence were provided by the National Park Service.

\section{Commodities:}

Main: $\mathrm{Cu}$

Other:

Ore minerals:

Gangue minerals:

\section{Geologic description:}

An unpublished National Park Service map and accompanying database identify this as a copper prospect. Bedrock in this drainage is dominantly Permian argillite and siliceous siltstone that is intruded by abundant gabbro dikes, sills, and irregular bodies that are inferred to be Triassic in age (Richter, 1971 [I-656]; 1976). Triassic, Nikolai Greenstone makes up the bedrock in the headwaters of Camp Creek, where there is a copper occurrence $(\mathrm{NB} 025)$.

\section{Alteration:}

Age of mineralization:

Deposit model:

Deposit model number (After Cox and Singer, 1986 or Bliss, 1992):

Production Status: None 
Site Status: Inactive

Workings/exploration:

Production notes:

\section{Reserves:}

Additional comments:

The prospect is in the Wrangell-St. Elias National Preserve.

\section{References:}

Richter, 1971 (I-656\}; Richter, 1976.

Primary reference: This record

Reporter(s): Travis L. Hudson (Applied Geology)

Last report date: $11 / 24 / 02$ 
Site name(s): Rebo

Site type: Prospect

ARDF no.: $\mathrm{NB} 028$

Latitude: 62.2687

Quadrangle: NB B-4

Longitude: 142.5202

\section{Location description and accuracy:}

This prospect is near the winter trail west of Cooper Pass. It is at an elevation of about 5,300 feet, about 6,000 feet south of elevation 6376 (Cooper). The site is in the SW1/4 of section 30, T. 6 N., R. 16 E. of the Copper River Meridian. This is National Park Service locality WRST-38 (unpublished data) and the coordinates for this prospect were provided by the National Park Service.

\section{Commodities:}

Main: $\mathrm{Au}, \mathrm{Cu}$

\section{Other:}

\section{Ore minerals:}

\section{Gangue minerals:}

\section{Geologic description:}

An unpublished National Park Service map and accompanying database identify this prospect. Five lode claims for copper and gold were staked at this locality and were active from 1974 to 1980 (U.S. Bureau of Mines, 1994). The northern contact of the midCretaceous Nabesna pluton (Richter, Lanphere, and Matson, 1975) intrudes Triassic limestone on the east-facing slopes about 2,000 feet southwest of this prospect (Richter, 1971 [I-656], 1976).

\section{Alteration:}

\section{Age of mineralization:}

Mid-Cretaceous? If the deposit is related to emplacement of the Nabesna pluton, it is mid-Cretaceous; K/Ar dates for the pluton range from $105+/-4.0$ to $114+/-3.4 \mathrm{Ma}$ (Richter, Lanphere, and Matson, 1975).

\section{Deposit model:}

Cu skarn? (Cox and Singer, 1986; model 18b) 
Deposit model number (After Cox and Singer, 1986 or Bliss, 1992):

$18 \mathrm{~b}$ ?

Production Status: None

Site Status: Inactive

Workings/exploration:

Some surface prospecting has occurred in this area.

Production notes:

Reserves:

Additional comments:

The prospect is in the Wrangell-St. Elias National Preserve.

\section{References:}

Richter, 1971 (I-656); Richter, Lanphere, and Matson, 1975; Richter, 1976; U. S. Bureau of Mines, 1994.

Primary reference: This record

Reporter(s): Travis L. Hudson (Applied Geology)

Last report date: $11 / 24 / 02$ 


\section{Site name(s): Unnamed (north of upper Antler Creek)}

Site type: Occurrence

ARDF no.: NB029

Latitude: 62.4242

Quadrangle: NB B-3

Longitude: 142.3138

\section{Location description and accuracy:}

This occurrence is north of upper Antler Creek; it is at an elevation of about 6,700 feet, about 500 feet south-southwest of peak 7144. The site is in the SE1/4 of section 32, T. 8 N., R. 17 E. of the Copper River Meridian. This is locality 36 of Richter and others (1975). It is located to within about 100 feet.

\section{Commodities:}

Main: $\mathrm{Cu}$

Other:

Ore minerals: Bornite, chalcopyrite, pyrite

Gangue minerals: Quartz

\section{Geologic description:}

This occurrence consists of quartz veinlets with minor chalcopyrite, pyrite, and bornite; the veinlets cut hornblende syenodiorite of the Antler Creek pluton (Richter, 1975; Richter and others, 1975). The Antler Creek pluton is part of a mid-Cretaceous intrusive suite associated with copper skarn and porphyry deposits elsewhere in the Nabesna quadrangle (e.g.. NB022 and NB043). A K/Ar date on hornblendite in the border zone of the Antler Creek pluton is 105 +/- 2.8 Ma (Richter, 1975; Richter, Lanphere, and Matson, 1975).

\section{Alteration:}

Oxidation? Richter (1975) reports that copper staining is commonly present at mineralized occurrences in this area.

Age of mineralization:

Mid-Cretaceous. A K/Ar date for the Antler Creek pluton is 105 +/- 2.8 Ma (Richter, Lanphere, and Matson, 1975).

\section{Deposit model:}

Copper-bearing vein 
Deposit model number (After Cox and Singer, 1986 or Bliss, 1992):

Production Status: None

Site Status: Inactive

Workings/exploration:

Probably only surface examination.

Production notes:

Reserves:

Additional comments:

The occurrence is in the Wrangell-St. Elias National Preserve.

\section{References:}

Richter, 1975; Richter and others, 1975; Richter, Lanphere, and Matson, 1975.

Primary reference: Richter and others, 1975

Reporter(s): Travis L. Hudson (Applied Geology)

Last report date: $11 / 24 / 02$ 


\section{Site name(s): Unnamed (north of upper Antler Creek)}

Site type: Occurrence

ARDF no.: NB030

Latitude: 62.4147

Quadrangle: NB B-3

Longitude: 142.2998

\section{Location description and accuracy:}

This occurrence is on the nose of a small, east-trending ridge near the center of section 5, T. 7 N., R. 17 E. of the Copper River Meridian. It is at an elevation of about 5,700 feet, 4,800 feet southeast of peak 7144. This is locality 37 of Richter and others (1975). It is located to within a few hundred feet.

\section{Commodities:}

Main: $\mathrm{Cu}$

Other:

Ore minerals: Chalcopyrite, pyrite

\section{Gangue minerals:}

\section{Geologic description:}

This occurrence consists of segregations of pyrite and chalcopyrite in the hornblendite, border zone of the Antler Creek pluton (Richter and others, 1975). The Antler Creek pluton is part of a mid-Cretaceous intrusive suite associated with copper skarn and porphyry deposits elsewhere in the Nabesna quadrangle (e.g., NB022 and NB043). A K/Ar date on hornblendite in the border zone of the Antler Creek pluton is $105+/-2.8 \mathrm{Ma}$ (Richter, 1975; Richter, Lanphere, and Matson, 1975).

\section{Alteration:}

Age of mineralization:

Related to Mid-Cretaceous pluton A K/Ar date on hornblendite in the border zone of the Antler Creek pluton is 105 +/- 2.8 Ma (Richter, 1975; Richter, Lanphere, and Matson, 1975).

\section{Deposit model:}

Chalcopyrite segregations in hornblendite

Deposit model number (After Cox and Singer, 1986 or Bliss, 1992): 
Production Status: None

Site Status: Inactive

Workings/exploration:

Probably only surface examination.

Production notes:

Reserves:

Additional comments:

The occurrence is in the Wrangell-St. Elias National Preserve.

\section{References:}

Richter, 1975; Richter and others, 1975; Richter, Lanphere, and Matson, 1975.

Primary reference: Richter and others, 1975

Reporter(s): Travis L. Hudson (Applied Geology)

Last report date: 11/24/02 


\section{Site name(s): Unnamed (northwest of Cooper Pass)}

Site type: Prospect

ARDF no.: NB031

Latitude: 62.2661

Quadrangle: NB B-3

Longitude: 142.4879

Location description and accuracy:

This prospect is near elevation 6185, about 3,500 feet northwest of Cooper Pass. The site is about 0.3 mile south of the center of section 29, T. 6 N,. R. 16 E. of the Copper River Meridian. This is National Park Service locality WRST-39 (unpublished data) and the coordinates for this prospect were provided by the National Park Service.

\section{Commodities:}

Main: $\mathrm{Au}, \mathrm{Cu}$

Other:

Ore minerals:

Gangue minerals:

\section{Geologic description:}

A National Park Service map and accompanying database identify this prospect. Lode claims for copper and gold were apparently located in this area about 1970 (U.S. Bureau of Mines, 1994). The prospect appears to be near the contact between Triassic limestone and Nikolai Greenstone (Richter, 1976).

\section{Alteration:}

Age of mineralization:

Deposit model:

Deposit model number (After Cox and Singer, 1986 or Bliss, 1992):

Production Status: None

Site Status: Inactive

Workings/exploration: 
Some surface prospecting has occurred in this area.

Production notes:

Reserves:

Additional comments:

The prospect is in the Wrangell-St. Elias National Preserve.

\section{References:}

Richter, 1976; U. S. Bureau of Mines, 1994.

Primary reference: This record

Reporter(s): Travis L. Hudson (Applied Geology)

Last report date: $11 / 24 / 02$ 


\section{Site name(s): Unnamed (near Sheep Creek)}

Site type: Prospect

ARDF no.: NB032

Latitude: 62.2671

Quadrangle: NB B-2

Longitude: 141.8108

\section{Location description and accuracy:}

This prospect is near the mouth of Sheep Creek on the Chisana River. The site is at about the center of the SW1/4 of section 25, T. 6 N., R. 19 E of the Copper River Meridian. This is National Park Service locality WRST-93 (unpublished data) and the coordinates for this prospect were provided by the National Park Service.

\section{Commodities:}

Main: $\mathrm{Cu}$

Other:

Ore minerals:

Gangue minerals:

\section{Geologic description:}

An unpublished National Park Service map and accompanying database identify this prospect. The database indicates that a lode mining claim for copper in basalt was located in this area between 1975 and 1981 by the Sheep Creek Mining Company. The bedrock in the surrounding area is part of the Jurassic or Cretaceous, Nutzotin Mountains sequence of marine clastic, sedimentary rocks (Richter, 1976). No other basalt-hosted copper occurrences is known in this sequence.

\section{Alteration:}

Age of mineralization:

\section{Deposit model:}

Deposit model number (After Cox and Singer, 1986 or Bliss, 1992):

Production Status: None

Site Status: Inactive 
Workings/exploration:

A camp site was located here and refuse remains.

Production notes:

Reserves:

Additional comments:

The prospect is in the Wrangell-St. Elias National Preserve.

References:

Richter, 1976.

Primary reference: This record

Reporter(s): Travis L. Hudson (Applied Geology)

Last report date: $11 / 24 / 02$ 


\section{Site name(s): Carden Hills}

Site type: Prospect

ARDF no.: NB033

Latitude: 62.2967

Quadrangle: NB B-1

Longitude: 141.1985

\section{Location description and accuracy:}

This prospect is on the south flank of the Carden Hills. The prospect is about 0.3 mile west of the center of section 17, T. 6 N., R. 23 E. of the Copper River Meridian. It is National Park Service locality WRST-77 (unpublished data) and coordinates for this prospect were provided by the National Park Service.

\section{Commodities:}

Main: $\mathrm{Cr}$

\section{Other:}

Ore minerals: Chromite

\section{Gangue minerals:}

\section{Geologic description:}

At this prospect, chromite is disseminated in serpentinized peridotite ), which is part of a gabbro, anorthosite, and ultramafic complex that extends for over 4 miles along the south side of the Carden Hills (Richter, 1976; Foley and others, 1985; U. S. Bureau of Mines , 1994; MILS \#0020780128). The serpentine replaces peridotite and dunite located on the northeast side of the complex.

\section{Alteration:}

Serpentinization.

Age of mineralization:

Paleozoic? This is the inferred age of the of the mafic-ultramafic complex (Richter, 1976).

\section{Deposit model:}

Podiform chromite (Cox and Singer, 1986; model 8a)

Deposit model number (After Cox and Singer, 1986 or Bliss, 1992): $8 \mathrm{a}$ 
Production Status: None

Site Status: Probably inactive

Workings/exploration:

Production notes:

Reserves:

Additional comments:

The prospect is in the Wrangell-St. Elias National Preserve.

References:

Richter, 1976; Foley and others, 1985; U. S. Bureau of Mines, 1994.

Primary reference: Foley and others, 1985

Reporter(s): Travis L. Hudson (Applied Geology)

Last report date: $11 / 24 / 02$ 


\section{Site name(s): Unnamed (east of Snag Creek)}

Site type: Prospect

ARDF no.: NB034

Latitude: 62.2497

Quadrangle: NB B-1

Longitude: 141.4502

\section{Location description and accuracy:}

This placer(?) prospect is on the alluvial fan at the northwest end of the mountains, north of the east fork of Snag Creek. It is at an elevation of about 3,400 feet, about 1 mile east of Snag Creek. The prospect is in the SE1/4 of section 35, T. 6 N., R. 21 E. of the Copper River Meridian. This is National Park Service locality WRST-76 (unpublished data) and the coordinates of this prospect were provided by the National Park Service.

\section{Commodities:}

Main: Au?

Other:

Ore minerals: Gold?

\section{Gangue minerals:}

\section{Geologic description:}

An unpublished National Park Service map and accompanying database identify this prospect. There are two patented mining claims (Mineral Survey MS1552) and they are assumed to have been located for placer gold. Bedrock in the area is part of the Jurassic or Cretaceous Nutzotin Mountains sequence of marine clastic sedimentary rocks (Richter, 1976).

\section{Alteration:}

Age of mineralization:

Quaternary?

\section{Deposit model:}

Placer Au? (Cox and Singer, 1986; model 39a)

Deposit model number (After Cox and Singer, 1986 or Bliss, 1992): $39 a$ ? 
Production Status: Undetermined.

Site Status: Inactive

Workings/exploration:

Some surface prospecting and deposit evaluation has occurred here.

Production notes:

Reserves:

Additional comments:

The prospect is in the Wrangell-St. Elias National Preserve.

\section{References:}

Richter, 1976.

Primary reference: This record

Reporter(s): Travis L. Hudson (Applied Geology)

Last report date: $11 / 24 / 02$ 


\section{Site name(s): Unnamed (west of Monte Cristo Creek)}

Site type: Occurrence

\section{ARDF no.: NB035}

Latitude: 62.2128

Quadrangle: NB A-5

Longitude: 143.0209

\section{Location description and accuracy:}

This occurrence is at an elevation of about 4,900 feet on the north valley-wall of Monte Cristo Creek valley near the point that the creek crosses the east boundary of the Nabesna A-5 quadrangle. The site coincides with one shown on an unpublished National Park Service map; it is near the center of the SW1/4 of section 9, T. 5 N., R. 13 E. of the Copper River Meridian. This is National Park Service locality WRST-19 (unpublished data) and the coordinates for this occurrence were provided by the National Park Service.

\section{Commodities:}

Main: $\mathrm{Au}$

\section{Other:}

Ore minerals: Gold, pyrite?

Gangue minerals: Gypsum, quartz

\section{Geologic description:}

An unpublished National Park Service map and accompanying database identify this locality as a porphyry gold prospect. Bedrock in this part of Monte Cristo Creek is marine and subaerial volcanic and volcaniclastic rocks of the Lower Cretaceous, Chisana Formation (Richter, 1976). Nearly horizontal volcanic rocks of the upper Tertiary and Quaternary, Wrangell Lava unconformably overly the Chisana Formation. The Chisana Formation is extensively hydrothermally altered and is characteristically replaced by gypsumquartz-sulfide assemblages (Richter, 1976). Tertiary hornblende-plagioclase porphyry crops out downstream in Monte Cristo Creek in the Nabesna A-4 quadrangle. A K/Ar age for this porphyry is $17 \mathrm{Ma}$ (Richter, 1973).

\section{Alteration:}

Gypsum-quartz-sulfide (pyrite?) replacement of Chisana Formation volcanic rocks. Oxidation is shown by abundant iron-oxide staining.

\section{Age of mineralization:}

Tertiary? Hydrothermal alteration may be related to the emplacement of a hornblende- 
plagioclase porphyry downstream in the Nabesna A-4 quadrangle; the porphyry has a 17 Ma K/Ar age (Richter, 1973).

\section{Deposit model:}

Porphyry gold?

Deposit model number (After Cox and Singer, 1986 or Bliss, 1992):

Production Status: None

Site Status: Inactive

Workings/exploration:

Production notes:

Reserves:

Additional comments:

The prospect is in the Wrangell-St. Elias National Preserve.

References:

Richter, 1973; Richter, 1976.

Primary reference: This record

Reporter(s): Travis L. Hudson (Applied Geology)

Last report date: $11 / 24 / 02$ 


\section{Site name(s): Unnamed (south of Monte Cristo Creek)}

Site type: Occurrence

ARDF no.: NB036

Latitude: 62.1988

Quadrangle: NB A-5

Longitude: 143.0179

\section{Location description and accuracy:}

This occurrence is at an elevation of about 4,500 feet on the south valley wall of Monte Cristo Creek, about 1.1 miles southeast of elevation 6210, and 1.4 miles east-northeast of elevation 5535. The site is in the NW1/4 of section 21, T. 5 N., R. 13 E. of the Copper River Meridian. This is National Park Service locality WRST-21 (unpublished data) and the coordinates for this occurrence were provided by the National Park Service.

\section{Commodities:}

Main: Mo

\section{Other:}

Ore minerals: Molybdenite, pyrite?

Gangue minerals: Gypsum, quartz

\section{Geologic description:}

An unpublished National Park Service map and accompanying database identify this locality as a porphyry molybdenum prospect. Bedrock in this part of Monte Cristo Creek is marine and subaerial volcanic and volcaniclastic rocks of the Lower Cretaceous, Chisana Formation (Richter, 1976). Nearly horizontal volcanic rocks of the upper Tertiary and Quaternary, Wrangell Lava unconformably overly the Chisana Formation. The Chisana Formation is extensively hydrothermally altered and characteristically replaced by gypsum-quartz-sulfide assemblages (Richter, 1976). Tertiary hornblende-plagioclase porphyry crops out downstream in Monte Cristo Creek in the Nabesna A-4 quadrangle. A K/ Ar age for this porphyry is $17 \mathrm{Ma}$ (Richter, 1973). A porphyry molybdenite prospect (NB037) located downstream just inside the Nabesna A-4 quadrangle is at the contact of a granodiorite pluton inferred to be mid-Cretaceous in age (Richter, 1976).

\section{Alteration:}

Gypsum-quartz-sulfide (pyrite?) replacement of Chisana Formation volcanic rocks. Oxidation is evidenced by abundant iron-oxide staining.

Age of mineralization: 
Cretaceous or Tertiary? Hydrothermal alteration may be related to emplacement of hornblende-plagioclase porphyry downstream in the Nabesna A-4 quadrangle that has a $17 \mathrm{Ma}$ K/Ar age (Richter, 1973). A porphyry molybdenite prospect (NB037) downstream just inside the Nabesna A-4 quadrangle is at the contact of a granodiorite pluton inferred to be mid-Cretaceous (Richter and others, 1975).

Deposit model:

Porphyry Mo, low-F (Cox and Singer, 19086; model 21b)

Deposit model number (After Cox and Singer, 1986 or Bliss, 1992):

$21 b$

Production Status: None

Site Status: Inactive

Workings/exploration:

Production notes:

Reserves:

Additional comments:

The prospect is in the Wrangell-St. Elias National Preserve.

References:

Richter, 1973; Richter and others, 1975; Richter, 1976.

Primary reference: This record

Reporter(s): Travis L. Hudson (Applied Geology)

Last report date: $11 / 24 / 02$ 


\section{Site name(s): Monte Cristo Creek; Marie Nabesna}

Site type: Prospect

ARDF no.: NB037

Latitude: 62.2187

Quadrangle: NB A-4

Longitude: 142.9976

\section{Location description and accuracy:}

This prospect is at an elevation of about 3,600 feet on Monte Cristo Creek. It is about 3.6 miles upstream of the mouth of the creek and near the west boundary of the Nabesna A-4 quadrangle. The site is in the NE1/4 of section 16, T. 5 N., R. 13 E. of the Copper River Meridian. This is locality 1 of Richter (1973), locality 16 of Richter and others (1975), and National Park Service locality WRST-20 (unpublished data). Cobb and Richter (1980) included this prospect under the name 'Monte Cristo Cr.'. It is located to within a few hundred feet.

\section{Commodities:}

Main: Mo

\section{Other:}

Ore minerals: Molybdenite, pyrite

Gangue minerals: Gypsum, quartz

\section{Geologic description:}

Disseminated molybdenite and quartz-pyrite-molybdenite veins occur in hydrothermally altered volcanic breccia of the Lower Cretaceous, Chisana Formation at its contact with a granodiorite pluton (Richter and others, 1975). A composite chip sample across 200 feet of the contact contained 5 parts per million molybdenum and 100 parts per million copper (Richter and Matson, 1970 [OFR 70-276]). The volcanic rocks of the Chisana Formation are extensively replaced by gypsum-quartz-pyrite assemblages in this part of Monte Cristo Creek (Richter and Matson, 1970 [OFR 70-276]; Richter, 1973, 1976). Richter and others (1975) and Richter, Lanphere, and Matson (1975) consider the granodiorite to be part of the mid-Cretaceous Nabesna pluton that has been dated by K/Ar methods as from $105+/-4.0$ to $114+/-3.4 \mathrm{Ma}$.

\section{Alteration:}

Oxidation is indicated by abundant iron-oxide staining. This part of Monte Cristo Creek is marked by extensive gypsum-quartz-pyrite replacement of the volcanic rocks of the Chisana Formation (Richter, 1973; 1976). 


\section{Age of mineralization:}

Mid-Cretaceous. The deposit is at the contact of a granodiorite considered to be part of the mid-Cretaceous Nabesna pluton for which K/Ar dates range from 105 +/- 4.0 to 114 +/- 3.4 Ma (Richter and others, 1975; Richter, Lanphere, and Matson, 1975).

\section{Deposit model:}

Porphyry Mo, Low-F (Cox and Singer, 1986; model 21b)

Deposit model number (After Cox and Singer, 1986 or Bliss, 1992):

$21 b$

\section{Production Status: No}

Site Status: Inactive

Workings/exploration:

The deposit has been prospected one or more times since 1967.

\section{Production notes:}

\section{Reserves:}

The porphyry molybdenum deposits in the Nabesna quadrangle are each estimated to contain 50 million tons grading 0.01 percent molybdenum (Richter and others, 1975).

\section{Additional comments:}

The prospect is in the Wrangell-St. Elias National Preserve.

\section{References:}

Richter and Matson, 1970 (OFR 70-276); Richter, 1973; Richter and others, 1975; Richter, Lanphere, and Matson, 1975; Richter, 1976; Cobb and Richter, 1980.

Primary reference: Richter and others, 1975

Reporter(s): Travis L. Hudson (Applied Geology)

Last report date: $11 / 24 / 02$ 


\section{Site name(s): Unnamed (northwest of terminus of Nabesna Glacier)}

Site type: Prospect

ARDF no.: NB038

Latitude: 62.2003

Quadrangle: NB A-4

Longitude: 142.9503

\section{Location description and accuracy:}

This prospect is on the west side of Nabesna River valley about 1.5 miles northwest of the terminus of Nabesna Glacier. It is at an elevation of about 3,500 feet, 5,500 feet northwest of hill 3290. The site is near the center of section 28, T. 5 N., R. 13 E. of the Copper River Meridian. This is locality 5 of Richter (1973), locality 17 of Richter and others (1975), and at least close to National Park Service locality WRST-23 (unpublished data). It was included by Cobb and Richter (1980) as an 'Unnamed prospect'. It is located to within a few hundred feet.

\section{Commodities:}

Main: $\mathrm{Ag}, \mathrm{Au}$

Other: $\mathrm{Cu}, \mathrm{Pb}, \mathrm{Zn}$

Ore minerals: Chalcopyrite, galena, gold, sphalerite

Gangue minerals: Quartz

\section{Geologic description:}

Abundant quartz veins and irregular pods of quartz up to 1 foot thick in recrystallized Triassic limestone contain sphalerite, galena, and minor chalcopyrite. A chip sample across a 6-inch-wide sphalerite-chalcopyrite-galena vein contained 2.4 parts per million (ppm) gold, 200 ppm silver, and more than 2 percent copper, 2 percent lead, and 1 percent zinc (Richter and Matson, 1970 [OFR 70-276]). A chip sample across a 1-foot-wide quartz vein contained 0.2 parts per million (ppm) gold, 150 ppm silver, 300 ppm molybdenum, 5,000 ppm copper, 5,000 ppm lead, and 7,000 ppm zinc. The prospect is in the contact zone of the mid-Cretaceous Nabesna pluton (Richter, 1973). K/Ar dates for the Nabesna pluton range in age from $105+/-4.0$ to 114 +/- 3.4 Ma (Richter and others, 1975; Richter, Lanphere, and Matson, 1975).

\section{Alteration:}

Recrystallization of limestone adjacent a granodiorite pluton. Oxidation.

Age of mineralization: 
Mid-Cretaceous. K/Ar dates for the Nabesna pluton range from $105+/-4.0$ to 114 +/3.4 Ma (Richter and others, 1975; Richter, Lanphere, and Matson, 1975).

\section{Deposit model:}

Polymetallic veins (Cox and Singer, 1986; model 22c)

Deposit model number (After Cox and Singer, 1986 or Bliss, 1992):

$22 \mathrm{c}$

Production Status: None

Site Status: Inactive

Workings/exploration:

Small prospect pits have been dug on the veins.

Production notes:

\section{Reserves:}

\section{Additional comments:}

The prospect is in the Wrangell-St. Elias National Preserve.

\section{References:}

Richter and Matson, 1970 (OFR 70-276); Richter, 1973; Richter and others, 1975; Richter, Lanphere, and Matson, 1975; Cobb and Richter, 1980.

Primary reference: Richter and Matson, 1970 (OFR 70-276)

Reporter(s): Travis L. Hudson (Applied Geology)

Last report date: $11 / 24 / 02$ 


\section{Site name(s): Unnamed (terminus of Nabesna Glacier)}

Site type: Prospect

ARDF no.: NB039

Latitude: 62.1892

Quadrangle: NB A-4

Longitude: 142.9229

\section{Location description and accuracy:}

This prospect is on the southeast side of a small hill (whose summit is at an elevation of 3,290 feet) near the terminus of Nabesna Glacier. It is at an elevation of about 3,100 feet and about 500 feet west of Nabesna River. The prospect is about 0.3 mile north of the center of section 25, T. 5 N., R. 13 E. of the Copper River Meridian. This is locality 6 of Richter (1973), locality 18 of Richter and others (1975), and National Park Service locality WRST-24 (unpublished data). Cobb and Richter (1980) included this prospect under the name 'Nabesna River'. It is located to within a few hundred feet.

\section{Commodities:}

Main: $\mathrm{Cu}$

Other: $\mathrm{Ag}, \mathrm{Zn}$

Ore minerals: Chalcopyrite, pyrite

Gangue minerals: Quartz

\section{Geologic description:}

A stockwork of quartz-pyrite veins and veinlets, containing minor chalcopyrite, cuts an altered Tertiary hornblende porphyry dacite dike and Triassic, Nikolai Greenstone. A composite chip sample across 200 feet of altered porphyry contained 1,500 parts per million copper (Richter and Matson, 1970 [OFR 70-276]). Some drilling in this deposit indicates grades as high as 0.3 percent copper, with minor silver and zinc values (Richter and others, 1975). The prospect is near the southwest margin of the mid-Cretaceous Nabesna pluton. K/Ar dates for the Nabesna pluton range from $105+/-4.0$ to $114+/-3.4 \mathrm{Ma}$ (Richter, Lanphere, and Matson, 1975; Richter and others, 1975). The porphyry is inferred to be Tertiary because similar rocks on Monte Cristo Creek and Cross Creek have 17 and 39 Ma K/Ar ages (Richter, 1973).

\section{Alteration:}

Unspecified hydrothermal alteration of the porphyry (Richter and Matson, 1970 [OFR 70-276]). 
Age of mineralization:

Tertiary. Veins cut a porphyry inferred to be Tertiary in age.

Deposit model:

Vein stockwork

Deposit model number (After Cox and Singer, 1986 or Bliss, 1992):

Production Status: None

Site Status: Inactive

Workings/exploration:

Surface exploration and some diamond drilling.

Production notes:

Reserves:

Additional comments:

The prospect is in the Wrangell-St. Elias National Preserve.

References:

Richter and Matson, 1970 (OFR 70-276); Richter, 1973; Richter and others, 1975; Richter, Lanphere, and Matson, 1975; Cobb and Richter, 1980.

Primary reference: Richter and others, 1975

Reporter(s): Travis L. Hudson (Applied Geology)

Last report date: $11 / 24 / 02$ 


\section{Site name(s): Unnamed (west of lower Nabesna Glacier)}

Site type: Occurrence

ARDF no.: NB040

Latitude: 62.1519

Quadrangle: NB A-4

Longitude: 142.9218

\section{Location description and accuracy:}

This occurrence is along the west side of lower Nabesna Glacier. It is at an elevation of about 3,200 feet, about 400 feet west of the glacier. The occurrence is about 0.4 mile south-southwest of the center of section 6, T. 4 N., R. 14 E. of the Copper River Meridian. This is locality 9 of Richter (1973), locality 19 of Richter and others (1975), and National Park Service locality WRST-26 (unpublished data). Cobb and Richter (1980) included this locality as an 'Unnamed occurrence'. It is located to within a few hundred feet.

\section{Commodities:}

Main: $\mathrm{Cu}, \mathrm{Fe}$

Other:

Ore minerals: Chalcopyrite, magnetite

\section{Gangue minerals:}

\section{Geologic description:}

Massive magnetite containing pyrite and minor chalcopyrite is present in amphibolitized volcanic rock (Richter and others, 1975). The occurrence is near the contact of volcanic rock with a Tertiary porphyry intrusive. The volcanic rock was first thought to be part of an upper Paleozoic volcanic assemblage but Triassic, Nikolai Greenstone is present along most of the porphyry contact (Richter, 1973; 1976).

\section{Alteration:}

Amphibolitization of mafic volcanic rock.

Age of mineralization:

Tertiary; the age of the nearby porphyry is inferred to be Tertiary.

\section{Deposit model:}

Contact metasomatic $\mathrm{Cu}$ deposit 
Deposit model number (After Cox and Singer, 1986 or Bliss, 1992):

Production Status: None

Site Status: Inactive

Workings/exploration:

Production notes:

Reserves:

Additional comments:

The occurrence is in the Wrangell-St. Elias National Preserve.

\section{References:}

Richter, 1973; Richter and others, 1975; Cobb and Richter, 1980.

Primary reference: Richter and others, 1975

Reporter(s): Travis L. Hudson (Applied Geology)

Last report date: $11 / 24 / 02$ 


\section{Site name(s): Unnamed (west of lower Nabesna Glacier)}

Site type: Occurrence

ARDF no.: NB041

Latitude: 62.1468

Quadrangle: NB A-4

Longitude: 142.9239

\section{Location description and accuracy:}

This occurrence is along the west side of lower Nabesna Glacier. It is at an elevation of about 3,400 feet and about 700 feet west of the glacier. The occurrence is about 0.4 mile north-northwest of the center of section 7, T. 4 N., R. 14 E. of the Copper River Meridian. This is locality 10 of Richter (1973), locality 20 of Richter and others (1975), and National Park Service locality WRST-27 (unpublished data). Cobb and Richter (1980) included this locality as an 'Unnamed occurrence'. It is located to within a few hundred feet.

\section{Commodities:}

Main: $\mathrm{Au}, \mathrm{Co}$

Other:

Ore minerals: Cobaltite, gold

Gangue minerals: Calcite

\section{Geologic description:}

A 10- to 20-cm-wide calcite vein contains gold and cobaltite (Richter and others, 1975). The vein contains up to 10 ounces of gold per ton (Richter and others, 1975). The vein is in highly altered and limonite-stained Triassic, Nikolai Greenstone(?) near the contact with a Tertiary porphyry intrusion (Richter, 1973).

\section{Alteration:}

The host rock to the vein is strongly hydrothermally altered (Richter, 1973).

\section{Age of mineralization:}

Tertiary? The age of the nearby porphyry is inferred to be Tertiary.

\section{Deposit model:}

Vein

Deposit model number (After Cox and Singer, 1986 or Bliss, 1992): 
Production Status: None

Site Status: Inactive

Workings/exploration:

Production notes:

Reserves:

Additional comments:

The occurrence is in the Wrangell-St. Elias National Preserve.

References:

Richter, 1973; Richter and others, 1975; Cobb and Richter, 1980.

Primary reference: Richter and others, 1975

Reporter(s): Travis L. Hudson (Applied Geology)

Last report date: $11 / 24 / 02$ 


\section{Site name(s): Unnamed (west of lower Nabesna Glacier)}

Site type: Occurrence

\section{ARDF no.: NB042}

Latitude: 62.1283

Quadrangle: NB A-4

Longitude: 142.9363

\section{Location description and accuracy:}

This occurrence is on the east nose of a low ridge along the north side of a west tributary stream to lower Nabesna Glacier. It is at an elevation of about 3,800 feet, 2,500 feet west of the glacier and about 1.6 miles east-southeast of elevation 5370. The site is in the NE1/4 of section 13, T. 4 N., R. 13 E. of the Copper River Meridian. This is locality 11 of Richter (1973), locality 21 of Richter and others (1975), and National Park Service locality WRST-29 (unpublished data). Cobb and Richter (1980) included this locality as an 'Unnamed occurrence'. It is located to within a few hundred feet.

\section{Commodities:}

Main: $\mathrm{Cu}$

Other:

Ore minerals: Chalcopyrite, pyrite

\section{Gangue minerals:}

\section{Geologic description:}

Small irregular masses of pyrite and minor chalcopyrite occur in contactmetamorphosed Triassic, Nikolai Greenstone. A chip sample of pyrite-bearing greenstone contained 500 parts per million (ppm) copper, more than 100 ppm scandium, 200 ppm nickel, and 300 ppm chromium (Richter and Matson, 1970 [OFR 70-276]). This occurrence is in the contact zone of a diorite stock that is inferred to be a border phase of the mid-Cretaceous Nabesna pluton (Richter, 1973).

\section{Alteration:}

Tactite development in contact metamorphosed greenstone.

\section{Age of mineralization:}

Mid-Cretaceous? The nearby diorite stock is inferred to be a border phase of the midCretaceous Nabesna pluton (Richter, 1973).

\section{Deposit model:}


Contact metamorphic copper deposit

Deposit model number (After Cox and Singer, 1986 or Bliss, 1992):

Production Status: None

Site Status: Inactive

Workings/exploration:

Production notes:

Reserves:

Additional comments:

The occurrence is in the Wrangell-St. Elias National Preserve.

References:

Richter and Matson, 1970 (OFR 70-276); Richter, 1973; Richter and others, 1975; Cobb and Richter, 1980.

Primary reference: Richter and others, 1975

Reporter(s): Travis L. Hudson (Applied Geology)

Last report date: $11 / 24 / 02$ 


\section{Site name(s): Orange Hill}

Site type: Prospect

ARDF no.: NB043

Latitude: 62.2040

Quadrangle: NB A-4

Longitude: 142.8449

\section{Location description and accuracy:}

This prospect is on the northeast flank of Orange Hill. It is in an unnamed drainage that flows north-northwest to near the Orange Hill airstrip, which is 0.5 mile northwest of the prospect. The site is near the northeast corner of section 20, T. 5 N., R. 14 E. of the Copper River Meridian. This is locality 2 of Richter (1973), locality 22 of Richter and others (1975), and included in National Park Service locality WRST-31 (unpublished data). Cobb and Richter (1980) included this prospect under the name 'Orange Hill'. It is located to within a few hundred feet.

\section{Commodities:}

Main: $\mathrm{Ag}, \mathrm{Au}, \mathrm{Cu}, \mathrm{Mo}$

\section{Other:}

Ore minerals: Chalcopyrite, molybdenite, pyrite

Gangue minerals: Anhydrite, biotite, calcite, chlorite, epidote, gypsum, potassium feldspar, quartz, sericite

\section{Geologic description:}

The Orange Hill porphyry copper prospect was first discovered and staked as early as 1902 for its possible gold content (Mendenhall and Schrader, 1903). By 1940, 18 mining claims had been patented, including contiguous claims that extend southeast across contact metamorphic deposits (Moffit, 1943, 1954; also see NB044). Over the years, the prospect has been extensively explored by open cuts, short adits, and much diamond drilling.

Pyrite, chalcopyrite, and molybdenite occur in quartz veinlets and as disseminations in quartz diorite and granodiorite intruded by quartz plagioclase porphyry (Richter and others, 1975). Hydrothermal alteration is well developed in the Orange Hill deposit (Linn, 1973; Hollister and others, 1975; Richter and others, 1975). A central 400 by 2,000 meter altered zone contains abundant biotite, quartz veinlets, minor K-feldspar, chlorite, and sericite. It is cut by late anhydrite veins. An outer 1,000 by 3,000 meter altered zone contains chlorite, minor sericite, and anhydrite. The deposit has been extensively oxidized and iron-oxide staining is abundant. Surface copper grades are less than 0.4 percent and 
average about 0.25 percent. Surface molybdenum grades are as high as 0.8 percent but average about 0.01 percent. The average grade of the non-oxidized mineralization is estimated to be 0.35 percent copper and 0.02 percent molybdenum (Richter and others, 1975). Gold values range up to 0.04 ounce per ton and probably average about 0.005 ounce per ton (Van Alstine and Black, 1944; Richter and others, 1975 ). The average silver grade is estimated to be 0.01 ounce per ton (Van Alstine and Black, 1944). Three estimates of the tonnage and grade of the Orange Hill deposit are: 1) 210 million tons grading 0.04 per cent copper and 0.02 percent molybdenum (Van Alstine and Black, 1944); 2) 86 million tons grading 0.3 or more percent copper and 0.015 percent molybdenite (Linn, 1973); and 3) 320 million tons grading 0.35 percent copper and 0.02 percent molybdenum (Richter and others, 1975). Richter and others (1975) estimate the deposit contains 1.6 million ounces of gold and 3.2 million ounces of silver.

The Orange Hill deposit is within quartz diorite and granodiorite of the southwestern border zone of the mid-Cretaceous Nabesna pluton. The granitic rocks in turn are intruded by quartz-plagioclase porphyry that is also inferred to be Cretaceous in age (Richter, 1973). Many varieties of hornblende-plagioclase porphyry form irregular intrusive bodies in the Nabesna pluton and other regional bedrock units in the area; these are considered to be Tertiary in age (Richter, 1973). K/Ar ages for the Nabesna pluton range from $105+/-4.0$ to 114 +/- 3.4 Ma (Richter and others, 1975; Richter, Lanphere, and Matson, 1975). Country rocks to the Nabesna pluton at Orange Hill include upper Paleozoic metavolcanic rocks, Permian limestone, Permian or Triassic argillite, and Triassic, Nikolai Greenstone (Richter, 1973).

\section{Alteration:}

A central 400 by 2,000 meter altered zone contains abundant biotite, quartz veinlets, minor K-feldspar, chlorite, and sericite. It is cut by late anhydrite veins. An outer 1,000 by 3,000 meter altered zone contains chlorite, minor sericite, and anhydrite. The deposit has been extensively oxidized and iron-oxide staining is abundant.

\section{Age of mineralization:}

Mid-Cretaceous. The intrusive host rocks to the Orange Hill deposit are considered to be part of the Nabesna pluton. K/Ar ages for the Nabesna pluton range from $105+/-4.0$ to 114 +/- 3.4 Ma (Richter and others, 1975; Richter, Lanphere, and Matson, 1975). Many varieties of hornblende-plagioclase porphyry form irregular intrusive bodies into the Nabesna pluton and other regional bedrock units in the area; these are considered to be Tertiary in age (Richter, 1973).

\section{Deposit model:}

Porphyry Cu-Mo (Cox and Singer, 1986; model 21a)

\section{Deposit model number (After Cox and Singer, 1986 or Bliss, 1992): $21 \mathrm{a}$}

Production Status: None

Site Status: Inactive 


\section{Workings/exploration:}

The Orange Hill porphyry copper prospect was first discovered and staked as early as 1902 for its possible gold content (Mendenhall and Schrader, 1903). By 1940, 18 mining claims, a millsite, and a homestead had been patented. The mining claims include several contiguous claims that extend southeast across contact metamorphic deposits (Moffit, 1943; 1954; also see NB044). Over the years, the prospect has been extensively explored by open cuts, shafts, short adits, and much diamond drilling. The underground workings total only 250 to 300 feet and most were reported be caved by 1944 (Van Alstine and Black, 1944).

\section{Production notes:}

\section{Reserves:}

The average grade of the unoxidized mineralization is estimated to be 0.35 percent copper and 0.02 percent molybdenum (Richter and others, 1975). Gold values range up to 0.04 ounce per ton and probably average about 0.005 ounce per ton (Van Alstine and Black, 1944; Richter and others, 1975). The average silver grade is estimated to be 0.01 ounce per ton (Van Alstine and Black, 1944). Three estimates of the tonnage and grade of the Orange Hill deposit are: 1) 210 million tons grading 0.04 per cent copper and 0.02 percent molybdenum (Van Alstine and Black, 1944); 2) 86 million tons grading 0.3 or more percent copper and 0.015 percent molybdenite (Linn, 1973); and 3) 320 million tons grading 0.35 percent copper and 0.02 percent molybdenum (Richter and others, 1975). Richter and others (1975) estimate the deposit contains 1.6 million ounces of gold and 3.2 million ounces of silver.

\section{Additional comments:}

The prospect is in the Wrangell-St. Elias National Preserve.

\section{References:}

Mendenhall and Schrader, 1903; Moffit, 1943; Van Alstine and Black, 1944; Moffit, 1954; Richter, 1973; Linn, 1973; Richter and others, 1975; Richter, Lanphere, and Matson, 1975; Hollister and others, 1975; Cobb and Richter, 1980.

Primary reference: Richter and others, 1975

Reporter(s): Travis L. Hudson (Applied Geology)

Last report date: $11 / 24 / 02$ 


\section{Site name(s): Lemon; Copper King}

Site type: Prospect

ARDF no.: NB044

Latitude: 62.1920

Quadrangle: NB A-4

Longitude: 142.8201

\section{Location description and accuracy:}

This prospect is at an elevation of about 4,800 feet on the west flank of the high ridge east of Orange Hill. It is 1.1 miles southeast of the summit of Orange Hill and 1.2 miles southwest of peak 7521. The site is near the southeast corner of section 21, T. 5 N., R. 14 E. of the Copper River Meridian. This is locality 23 of Richter and others (1975) and it is included in National Park Service locality WRST-31 (unpublished data). Cobb and Richter (1980 [OFR 80-927]) included this prospect under the name 'Orange Hill'. It is probably located to within a thousand feet.

\section{Commodities:}

Main: $\mathrm{Ag}, \mathrm{Au}, \mathrm{Cu}, \mathrm{Fe}, \mathrm{Zn}$

\section{Other:}

Ore minerals: Azurite, bornite, chalcopyrite, chrysocolla, covellite, magnetite, malachite, molybdenite, powellite, pyrite, pyrrhotite, sphalerite, tetrahedrite

Gangue minerals: Diopside, epidote, garnet, wollastonite

\section{Geologic description:}

This skarn deposit was probably discovered and staked as part of the Orange Hill mineralized system as early as 1902 (Mendenhall and Schrader, 1903). By 1940, 18 mining claims had been patented, including contiguous claims that extend southeast from the Orange Hill porphyry-copper deposit across contact metamorphic deposits on the Lemon claims (Moffit, 1943, 1954). It has been explored by short adits and diamond drilling. The deposit on the Lemon claims contains disseminated pyrrhotite, pyrite, and chalcopyrite in magnetite-rich skarn and veins of pyrite, chalcopyrite, and sphalerite cutting magnetite bodies and skarn (Richter and others, 1975). Oxidation has produced local concentrations of chyrsocolla, malachite, azurite, and covellite. A 188-foot core sample from the Lemon Extension \#2 claim contained 0.3 to 3.8 percent copper and averaged 0.95 percent copper (Pilgrim, 1931). Channel samples from this claim had weighted averages of 0.71 percent copper, 0.024 ounce of gold per ton and 0.66 ounce silver per ton (Van Alstine and Black, 1944). An 8-foot long channel sample across a massive sulfide body 30 feet long and 3 to 8 feet wide assayed 0.32 percent copper, 0.08 ounce of gold 
per ton, 6.12 percent zinc, and 38.84 percent iron (Van Alstine and Black, 1944).

The deposit displays mineral zoning typical of porphyry copper-related copper skarns (Newberry and others, 1997). Red garnet with magnetite and chalcopyrite grades outward through zones with brown garnet, green garnet with bornite, to wollastonite with or without sphalerite. Diopside tends to occur with the brown and green garnet. The skarn is developed in Permian limestone adjacent to the Orange Hill porphyry copper deposit (NB043), which is hosted by quartz diorite and granodiorite of the mid-Cretaceous Nabesna pluton. K/Ar ages for the Nabesna pluton range from $105+/-4.0$ to $114+/-3.4 \mathrm{Ma}$ (Richter and others, 1975; Richter, Lanphere, and Matson, 1975). Many varieties of hornblende-plagioclase porphyry form irregular intrusive bodies in the Nabesna pluton and other regional bedrock units in the area; these are considered to be Tertiary in age (Richter, 1973).

\section{Alteration:}

Calc-silicate, sulfide, and magnetite replacement of limestone. Oxidation has produced chrysocolla, malachite, azurite, and covellite.

\section{Age of mineralization:}

Early Cretaceous. The skarn is developed in Permian limestone adjacent to the Orange Hill porphyry copper deposit (NB043), which is hosted by quartz diorite and granodiorite of the mid-Cretaceous Nabesna pluton. K/Ar ages for the Nabesna pluton range from 105 +/- 4.0 to 114 +/- $3.4 \mathrm{Ma}$ (Richter and others, 1975; Richter, Lanphere, and Matson, 1975).

\section{Deposit model:}

Cu skarn (Cox and Singer, 1986; model 18b)

\section{Deposit model number (After Cox and Singer, 1986 or Bliss, 1992): $18 \mathrm{~b}$}

Production Status: None

Site Status: Inactive

\section{Workings/exploration:}

This skarn deposit was probably discovered and staked as part of the Orange Hill mineralized system as early as 1902 (Mendenhall and Schrader, 1903). By 1940, 18 mining claims had been patented, including contiguous claims that extend southeast from the Orange Hill porphyry copper deposit across contact metamorphic deposits on the Lemon claims (Moffit, 1943, 1954). It has been explored by short adits and diamond drilling.

\section{Production notes:}

Reserves:

Additional comments: 
The prospect is in the Wrangell-St. Elias National Preserve.

\section{References:}

Mendenhall and Schrader, 1903; Pilgrim, 1931; Moffit, 1943; Van Alstine and Black, 1944; Moffit, 1954; Richter, 1973; Richter and others, 1975; Richter, Lanphere, and Matson, 1975; Cobb and Richter, 1980; Newberry and others, 1997.

Primary reference: Van Alstine and Black, 1944

Reporter(s): Travis L. Hudson (Applied Geology)

Last report date: $11 / 24 / 02$ 


\section{Site name(s): Unnamed (east of lower Nabesna Glacier)}

Site type: Prospect

ARDF no.: NB045

Latitude: 62.1548

Quadrangle: NB A-4

Longitude: 142.8302

\section{Location description and accuracy:}

This prospect is on the lower-west flank of the large ridge east of Nabesna Glacier. It is at an elevation of about 3,500 feet in a small drainage about 5,000 feet west of peak 6045 and 1,500 feet east of the glacier. The site is in the SW1/4 of section 3, T. 4 N., R. 14 E. of the Copper River Meridian. This is locality 7 of Richter (1973), locality 24 of Richter and others (1975), and National Park Service locality WRST-42 (unpublished data). Cobb and Richter (1980 [OFR 80-927]) include this locality as an 'Unnamed prospect'. It is located to within a few hundred feet.

\section{Commodities:}

Main: $\mathrm{Au}, \mathrm{Cu}$

\section{Other:}

Ore minerals: Chalcopyrite, gold, pyrite

Gangue minerals: Quartz, sericite

\section{Geologic description:}

Hydrothermally altered porphyry dikes and small masses of quartz diorite contain disseminated pyrite and chalcopyrite; local stockworks of quartz veins with pyrite and chalcopyrite also cut volcanic country rocks (Richter and Matson, 1970 [OFR 70-276]; Richter and others, 1975). Assays of 3 rock samples from this area contained 0.2 to 0.4 ounce gold per ton. One is a 200-foot composite chip sample of pyrite-bearing sericitized porphyry that contained 0.04 ounce of gold per ton and 2,000 parts per million copper (Richter and Matson, 1970 [OFR 70-276]). The altered intrusive rocks are Tertiary in age (Richter, 1973). They cut volcanic rocks and argillite of the upper Paleozoic Tetelna Volcanics (Richter, 1973; 1976).

\section{Alteration:}

Quartz-sericite-pyrite replacement and veining.

\section{Age of mineralization:}

The altered and mineralized intrusive rocks are considered to be Tertiary (Richter, 
1973).

\section{Deposit model:}

Disseminated and stockwork veins with copper and gold

Deposit model number (After Cox and Singer, 1986 or Bliss, 1992):

Production Status: None

Site Status: Inactive

Workings/exploration:

Surface prospecting has occurred in this area.

\section{Production notes:}

Reserves:

Additional comments:

The prospect is in the Wrangell-St. Elias National Preserve.

\section{References:}

Richter and Matson, 1970 (OFR 70-276); Richter, 1973; Richter and others, 1975; Richter, 1976; Cobb and Richter, 1980.

Primary reference: Richter and Matson, 1970 (OFR 70-276)

Reporter(s): Travis L. Hudson (Applied Geology)

Last report date: $11 / 24 / 02$ 


\section{Site name(s): Unnamed (east of lower Nabesna Glacier)}

Site type: Prospect

ARDF no.: NB046

Latitude: 62.1460

Quadrangle: NB A-4

Longitude: 142.8238

\section{Location description and accuracy:}

This prospect is on the lower-west flank of the large ridge east of Nabesna Glacier. It is at an elevation of about 3,500 feet, 1,500 feet east of the glacier and 5,300 feet northwest of peak 6224. The prospect is about 0.2 mile north of the center of section 10, T. 4 N., R. 14 E. of the Copper River Meridian. This is locality 8 of Richter (1973) and locality 25 of Richter and others (1975). Cobb and Richter (1980) include this locality as an 'Unnamed prospect'. It is located to within a few hundred feet.

\section{Commodities:}

Main: $\mathrm{Au}, \mathrm{Cu}$

\section{Other:}

Ore minerals: Chalcopyrite, gold, pyrite, sphalerite

Gangue minerals: Quartz, sericite

\section{Geologic description:}

Quartz-pyrite veins with minor chalcopyrite and sphalerite cut quartz-eye-bearing volcanic or intrusive rocks (Richter and others, 1975). A grab sample of sericitized quartz diorite from the area assayed 0.02 ounce gold per ton and 3,000 parts per million copper (Richter and Matson, 1970 [OFR 70-276]). Hornblende-plagioclase porphyry and small quartz diorite intrusives of Tertiary in age cut volcanic rocks of the upper Paleozoic Tetelna Volcanics in the area (Richter, 1973; 1976).

\section{Alteration:}

Quartz-sericite-pyrite replacement and veining.

\section{Age of mineralization:}

The altered and mineralized intrusive rocks are considered to be Tertiary (Richter, 1973).

\section{Deposit model:}

Quartz veins and disseminations with gold and copper 
Deposit model number (After Cox and Singer, 1986 or Bliss, 1992):

Production Status: None

Site Status: Inactive

Workings/exploration:

Some surface prospecting has occurred here.

Production notes:

Reserves:

Additional comments:

The prospect is in the Wrangell-St. Elias National Preserve.

\section{References:}

Richter and Matson, 1970 (OFR 70-276); Richter, 1973; Richter and others, 1975; Richter, 1976; Cobb and Richter, 1980.

Primary reference: Richter and Matson, 1970 (OFR 70-276)

Reporter(s): Travis L. Hudson (Applied Geology)

Last report date: $11 / 24 / 02$ 


\section{Site name(s): Unnamed (east of lower Nabesna Glacier)}

Site type: Occurrence

\section{ARDF no.: NB047}

Latitude: 62.1176

Quadrangle: NB A-4

Longitude: 142.8255

\section{Location description and accuracy:}

This occurrence is in an unnamed drainage on the lower-west flank of the large ridge east of Nabesna Glacier. It is at an elevation of about 4,000 feet, 7,800 feet northwest of peak 7445 and 3,000 feet east of the glacier. The occurrence is about 0.2 mile northeast of the center of section 22, T. 4 N., R. 14 E. of the Copper River Meridian. This is locality 13 of Richter (1973), locality 26 of Richter and others (1975), and National Park Service locality WRST-44 (unpublished data). Cobb and Richter (1980 [OFR 80-927]) included this locality as an 'Unnamed occurrence'. It is located to within a few hundred feet.

\section{Commodities:}

Main: $\mathrm{Cu}, \mathrm{Zn}$

\section{Other:}

Ore minerals: Chalcopyrite, pyrite, sphalerite

Gangue minerals: Quartz

\section{Geologic description:}

A quartz-pyrite vein with chalcopyrite and sphalerite cuts a quartz-eye- bearing rock that is either a volcanic flow rock or a shallow intrusive in upper Paleozoic, Tetelna Volcanics (Richter, 1973; Richter and others, 1975). A channel sample across a 1-foot-wide quartz vein with pyrite, chalcopyrite, and sphalerite contained 0.06 parts per million (ppm) gold, 15 ppm silver, more than 20,000 ppm copper, 700 ppm lead, and more than 10,000 ppm zinc (Richter and Matson, 1970 [OFR 70-276]).

\section{Alteration:}

Quartz veining.

\section{Age of mineralization:}

Cretaceous or Tertiary? The upper Paleozoic host rocks are locally cut by Cretaceous and Tertiary intrusive rocks associated with base metal mineralization elsewhere in the Nabesna A-4 quadrangle (Richter, 1973). 


\section{Deposit model:}

Polymetallic veins (Cox and Singer, 1986; model 22c)

Deposit model number (After Cox and Singer, 1986 or Bliss, 1992):

$22 \mathrm{c}$

Production Status: None

Site Status: Inactive

Workings/exploration:

Some surface prospecting has probably occurred here.

Production notes:

Reserves:

Additional comments:

The occurrence is in the Wrangell-St. Elias National Preserve.

\section{References:}

Richter and Matson, 1970 (OFR 70-276); Richter, 1973; Richter and others, 1975; Cobb and Richter, 1980.

Primary reference: Richter and others, 1975

Reporter(s): Travis L. Hudson (Applied Geology)

Last report date: $11 / 24 / 02$ 


\title{
Site name(s): Unnamed (east side of Nabesna Glacier)
}

Site type: Prospect

\author{
ARDF no.: NB048
}

Latitude: 62.1139

Quadrangle: NB A-4

Longitude: 142.8365

\section{Location description and accuracy:}

This prospect is on the lower-west flank of the ridge along the east side of Nabesna Glacier. It is at an elevation of about 3,500 feet, 600 feet east of the glacier, and 4,500 feet northwest of peak 5901. The site is in the SW1/4 of section 22, T. 4 N., R. 14 E. of the Copper River Meridian. This is locality 12 of Richter (1973) and locality 27 of Richter and others (1975). Cobb and Richter (1980) included this prospect under the name 'Nabesna Glacier'. It is located to within a few hundred feet.

\section{Commodities:}

Main: $\mathrm{Au}, \mathrm{Cu}, \mathrm{Zn}$

\section{Other:}

Ore minerals: Chalcopyrite, galena, gold, pyrite, sphalerite

Gangue minerals: Quartz

\section{Geologic description:}

An area 100 feet wide and 300 feet long is strongly hydrothermally altered and cut by abundant quartz-pyrite veins and veinlets (Richter and Matson, 1970 [OFR 70-276]; Richter and others, 1975). Alteration includes silicification, and oxidation has produced abundant iron-oxide staining and some copper staining. The veins contain some galena, sphalerite, and chalcopyrite. A random chip sample across 300 feet of copper-stained and silicified rock contained 300 parts per million (ppm) copper and a channel sample across a 2-foot-wide quartz-pyrite vein contained $0.02 \mathrm{ppm}$ gold, $30 \mathrm{ppm}$ silver, 15,000 ppm copper, 15,000 ppm lead, and more than 10,000 ppm zinc (Richter and Matson, 1970 [OFR 70-276]). The host rock is a buff to gray-green massive volcanic rock, locally brecciated and mineralized, that has quartz eyes up to 0.5 inch in diameter in a fine-grained matrix of quartz, feldspar, and white mica. The deposits occur in upper Paleozoic metavolcanic porphyry and metabasalt flows of the Tetelna Volcanics. Cretaceous and Tertiary granitic plutons and dikes, locally associated with base metal mineralization, intrude these host rocks in many parts of the Nabesna A-4 quadrangle (Richter, 1973).

\section{Alteration:}


Alteration includes silicification, and oxidation has produced abundant iron-oxide staining and some copper staining.

Age of mineralization:

Cretaceous or Tertiary? The upper Paleozoic host rocks are locally cut by Cretaceous and Tertiary intrusive rocks associated with base metal mineralization elsewhere in the Nabesna A-4 quadrangle (Richter, 1973).

\section{Deposit model:}

Polymetallic veins (Cox and Singer, 1986; model 22c)

Deposit model number (After Cox and Singer, 1986 or Bliss, 1992): $22 \mathrm{c}$

Production Status: None

Site Status: Inactive

Workings/exploration:

Some surface prospecting has probably occurred at the site.

Production notes:

Reserves:

Additional comments:

The prospect is in the Wrangell-St. Elias National Preserve.

\section{References:}

Richter and Matson, 1970 (OFR 70-276); Richter, 1973; Richter and others, 1975; Cobb and Richter, 1980.

Primary reference: Richter and Matson, 1970 (OFR 70-276)

Reporter(s): Travis L. Hudson (Applied Geology)

Last report date: $11 / 24 / 02$ 


\section{Site name(s): Unnamed (east of lower Nabesna Glacier)}

Site type: Occurrence

ARDF no.: NB049

Latitude: 62.0335

Quadrangle: NB A-4

Longitude: 142.8441

\section{Location description and accuracy:}

This occurrence is on the low, west-facing slopes along the east side of Nabesna Glacier. It is at an elevation of about 4,800 feet, 1,500 feet east of the glacier, and 2,800 feet south-southwest of elevation 5570. The occurrence is about 0.6 mile southeast of the center of section 16, T. 3 N., R. 14 E. of the Copper River Meridian. This is locality 18 of Richter (1973), locality 28 of Richter and others (1975), and National Park Service locality WRST-47 (unpublished data). Cobb and Richter (1980) included this locality as an 'Unnamed occurrence'. It is located to within a few hundred feet.

\section{Commodities:}

Main: $\mathrm{Cu}$

\section{Other:}

Ore minerals: Azurite, malachite

\section{Gangue minerals:}

\section{Geologic description:}

This is a 30- by 200-foot zone of malachite- and azurite-stained amygdaloidal basalt (Richter and others, 1975). A composite chip sample across 50 feet of copper-stained basalt contained more than 20,000 parts per million (ppm) copper and $1.5 \mathrm{ppm}$ silver (Richter and Matson, 1970 [OFR 70-276]). The basalt is part of the Triassic, Nikolai Greenstone (Richter, 1973). Copper mineralization is locally common in Nikolai Greenstone and is thought to have accompanied regional deformation and low-grade metamorphism in the Late Jurassic to Early Cretaceous (MacKevett and others, 1997).

\section{Alteration:}

\section{Age of mineralization:}

Cretaceous? Copper mineralization is locally common in Nikolai Greenstone and is thought to have accompanied regional deformation and low-grade metamorphism in the Late Jurassic to Early Cretaceous (MacKevett and others, 1997). 


\section{Deposit model:}

Basaltic copper (Cox and Singer, 1986; model 23)

Deposit model number (After Cox and Singer, 1986 or Bliss, 1992):

23

Production Status: None

Site Status: Inactive

Workings/exploration:

Production notes:

Reserves:

Additional comments:

The occurrence is in the Wrangell-St. Elias National Preserve.

\section{References:}

Richter and Matson, 1970 (OFR 70-276); Richter, 1973; Richter and others, 1975; Cobb and Richter, 1980; MacKevett and others, 1997.

Primary reference: Richter and Matson, 1970 (OFR 70-276)

Reporter(s): Travis L. Hudson (Applied Geology)

Last report date: $11 / 24 / 02$ 


\section{Site name(s): Unnamed (northeast of Nikonda Creek)}

Site type: Prospect

ARDF no.: NB050

Latitude: 62.1803

Quadrangle: NB A-4

Longitude: 142.7670

\section{Location description and accuracy:}

This prospect is on the west flank of the ridge northeast of Nikonda Creek. It is close to elevation 5346 and about 2,700 feet southwest of elevation 7870. The prospect is about 0.3 mile south-southwest of the center of section 26, T. 5 N., R. 14 E. of the Copper River Meridian. This is locality 4 of Richter (1973), locality 29 of Richter and others (1975), and National Park Service locality WRST-34 (unpublished data). Cobb and Richter (1980 include this locality as an 'Unnamed occurrence'. It is located to within a few hundred feet.

\section{Commodities:}

Main: $\mathrm{Au}, \mathrm{Cu}, \mathrm{Pb}$

\section{Other:}

Ore minerals: Chalcopyrite, galena, gold, pyrite

Gangue minerals: Quartz

\section{Geologic description:}

This prospect is a zone of intense hydrothermal alteration and brecciation in volcanic rocks of the upper Paleozoic, Tetelna Volcanics (Richter, 1973, 1976). The breccia is cemented by quartz containing minor chalcopyrite, pyrite and galena. Small unaltered to limonite-stained, porphyry intrusions cut the volcanic rocks (Richter and Matson, 1970 [OFR 70-276]). Rock samples from the area contain up to 0.9 parts per million (ppm) gold, 1,000 ppm lead, and 200 ppm copper (Richter and Matson, 1970 [OFR 70-276]).

\section{Alteration:}

Silicification and possibly other types of alteration.

\section{Age of mineralization:}

Cretaceous or Tertiary. The host rocks to the mineralization are late Paleozoic, but the porphyries are considered to be Tertiary (Richter, 1973, 1976). The mid-Cretaceous Nabesna pluton, spatially associated with porphyry copper deposits like that at Orange Hill (NB043), outcrops about 2 miles to the north. 


\section{Deposit model:}

Polymetallic veins? (Cox and Singer, 1986; model 22c)

Deposit model number (After Cox and Singer, 1986 or Bliss, 1992):

$22 \mathrm{c}$

Production Status: None

Site Status: Inactive

\section{Workings/exploration:}

At least surface prospecting has occurred at this site.

\section{Production notes:}

\section{Reserves:}

\section{Additional comments:}

The prospect is in the Wrangell-St. Elias National Preserve.

\section{References:}

Richter and Matson, 1970 (OFR 70-276); Richter, 1973; Richter and others, 1975; Richter, 1976; Cobb and Richter, 1980.

Primary reference: Richter and others, 1975

Reporter(s): Travis L. Hudson (Applied Geology)

Last report date: $11 / 24 / 02$ 


\section{Site name(s): Bond Creek}

Site type: Prospect

ARDF no.: NB051

Latitude: 62.1980

Quadrangle: NB A-4

Longitude: 142.7027

\section{Location description and accuracy:}

This prospect is on the ridge between the middle and west forks of Bond Creek. It is at an elevation of about 7,000 feet, 6,000 feet northwest of peak 8485 . The prospect is about 0.1 mile west of the center of section 19, T. 5 N., R. 15 E. of the Copper River Meridian. This is locality 3 of Richter (1973), locality 30 of Richter and others (1975), and National Park Service locality WRST-35 (unpublished data). This prospect was included by Cobb and Richter (1980) under the name 'Bond Cr.'. It is located to within a few hundred feet.

\section{Commodities:}

Main: $\mathrm{Ag}, \mathrm{Au}, \mathrm{Cu}, \mathrm{Mo}$

\section{Other:}

Ore minerals: Chalcopyrite, gold, molybdenite, pyrite

Gangue minerals: Quartz

\section{Geologic description:}

This porphyry copper-molydenum deposit was discovered in the 1960s and explored by some diamond drilling. Pyrite, chalcopyrite, and minor molybdenite occur in quartz veinlets and as disseminations in highly altered volcanic rocks, quartz diorite, and granodiorite intruded by leucocratic, quartz monzonite (Richter and others, 1975). The host rocks are altered over a 2.5 square kilometer area (Hollister and others, 1975; Richter and Matson, 1970 [OFR 70-276]; Richter, 1973). The alteration includes a 600- by 2,000(?)meter central zone with abundant chlorite, minor biotite and potassium feldspar, spotty sericite, and late anhydrite veins. A 2,000- by 3,000-meter outer zone has minor chlorite, epidote, and anhydrite. The deposit is estimated to contain 500 million tons with an average grade of 0.30 percent copper and 0.02 percent molybdenum; some gold and silver is also likely (Richter and others, 1975). The host rocks include part of the Paleozoic Tetelna Volcanics, granitic rocks of the mid-Cretaceous Nabesna pluton, and leucocratic, quartz monzonite porphyry (Richter, 1973, 1976; Richter and others, 1975). Dikes, irregular intrusions, and stocks of probably Tertiary, hornblende-plagioclase porphyry intrude the volcanic and granitic host rocks in nearby areas (Richter, 1973). 


\section{Alteration:}

The host rocks are altered over a 2.5 square kilometer area (Richter, 1973). The alteration includes a 600- by 2,000(?)-meter central zone with abundant chlorite, minor biotite and potassium feldspar, spotty sericite, and late anhydrite veins. A 2,000- by 3,000-meter outer zone has minor chlorite, epidote, and anhydrite.

\section{Age of mineralization:}

Mid-Cretaceous. The intrusive host rocks to the Bond Creek deposit are considered to be part of the Nabesna pluton. K/Ar ages for the Nabesna pluton range from $105+/-4.0$ to 114 +/- 3.4 Ma (Richter, Lanphere, and Matson, 1975; Richter and others, 1975). Many varieties of probably Tertiary hornblende-plagioclase porphyry form irregular intrusive bodies into the Nabesna pluton and other regional bedrock units in the area (Richter, 1973).

\section{Deposit model:}

Porphyry Cu-Mo (Cox and Singer, 1986; model 21a)

\section{Deposit model number (After Cox and Singer, 1986 or Bliss, 1992): $21 \mathrm{a}$}

Production Status: None

Site Status: Inactive

\section{Workings/exploration:}

This porphyry copper-molydenum deposit was discovered in the 1960s and explored by some diamond drilling.

\section{Production notes:}

\section{Reserves:}

The deposit is estimated to contain 500 million tons with an average grade of 0.30 percent copper and 0.02 percent molybdenum; some gold and silver values are also likely (Richter and others, 1975).

\section{Additional comments:}

The prospect is in the Wrangell-St. Elias National Preserve.

\section{References:}

Richter and Matson, 1970 (OFR 70-276); Richter, 1973; Linn, 1973; Richter and others, 1975; Richter, Lanphere, and Matson, 1975; Hollister and others, 1975; Richter, 1976; Cobb and Richter, 1980.

Primary reference: Richter and others, 1975 
Reporter(s): Travis L. Hudson (Applied Geology)

Last report date: $11 / 24 / 02$ 


\section{Site name(s): Unnamed (east fork Bond Creek)}

Site type: Prospect

ARDF no.: NB052

Latitude: 62.2353

Quadrangle: NB A-4

Longitude: 142.6778

\section{Location description and accuracy:}

This prospect is on the south side of the headwaters of the east fork of Bond Creek. It is at an elevation of about 5,600 feet, 1,700 feet south of Bond Creek, and 2 miles northwest of peak 8310. The prospect is about 0.5 mile north-northwest of the center of section 8 , T. 5 N., R. 15 E. of the Copper River Meridian. This is locality 19 of Richter (1973), locality 31 of Richter and others (1975), and National Park Service locality WRST-37 (unpublished data). Cobb and Richter (1980) included this prospect under the name 'East Fork'. It is located to within a few hundred feet.

\section{Commodities:}

Main: Mo

\section{Other:}

Ore minerals: Molybdenite, pyrite

Gangue minerals: Quartz

\section{Geologic description:}

Quartz-pyrite-molybdenite veins and veinlets cut strongly altered and brecciated trondhjemite. The trondhjemite forms an intrusive stock in other granitic rocks of the mid-Cretaceous Nabesna pluton (Richter, 1973). The deposit is estimated to contain 50 million tons with an average grade of about 0.01 percent molybdenum (Richter and others, 1975).

\section{Alteration:}

The host rocks to this deposit are highly altered but the type and extent of alteration have not been reported. The area is iron-stained.

\section{Age of mineralization:}

Mid-Cretaceous. The intrusive host rocks are part of the Nabesna pluton. K/Ar ages for the Nabesna pluton range from $105+/-4.0$ to $114+/-3.4 \mathrm{Ma}$ (Richter, Lanphere, and Matson, 1975). Many varieties of probably Tertiary hornblende-plagioclase porphyry form irregular intrusive bodies in the Nabesna pluton and other regional bedrock units in 
the area (Richter, 1973).

Deposit model:

Porphyry Mo, Low-F (Cox and Singer, 1986; model 21b)

Deposit model number (After Cox and Singer, 1986 or Bliss, 1992):

$21 b$

Production Status: None

Site Status: Inactive

Workings/exploration:

The prospect has been explored since 1967.

Production notes:

\section{Reserves:}

The deposit is estimated to contain 50 million tons with an average grade of about 0.01 percent molybdenum (Richter and others, 1975).

\section{Additional comments:}

The prospect is in the Wrangell-St. Elias National Preserve.

\section{References:}

Richter, 1973; Richter and others, 1975; Richter, Lanphere, and Matson, 1975; Cobb and Richter, 1980.

Primary reference: Richter and others, 1975

Reporter(s): Travis L. Hudson (Applied Geology)

Last report date: $11 / 24 / 02$ 


\section{Site name(s): Unnamed (head of middle fork Bond Creek)}

Site type: Occurrence

\section{ARDF no.: NB053}

Latitude: 62.1719

Quadrangle: NB A-4

Longitude: 142.6231

\section{Location description and accuracy:}

This occurrence is on the east side of the glacier at the head of the middle fork of Bond Creek. It is at an elevation of about 7,000 feet, 1,300 feet southwest of peak 8075, and 1,000 feet east of the glacier. The occurrence is about 0.4 mile west of the center of section 34, T. 5 N., R. 15 E. of the Copper River Meridian. It is locality 15 of Richter (1973), locality 32 of Richter and others (1975), and National Park Service locality WRST-40 (unpublished data). This locality is included as an 'Unnamed occurrence' by Cobb and Richter (1980). It is located to within a few hundred feet.

\section{Commodities:}

Main: $\mathrm{Cu}$

Other:

Ore minerals: Chalcopyrite, pyrite

Gangue minerals: Quartz

\section{Geologic description:}

At this occurrence, brecciated and highly altered volcanic rocks of the upper Paleozoic Tetelna Volcanics are cemented by quartz that contains minor pyrite and chalcopyrite (Richter, 1973; Richter and others, 1975; Richter, 1976). A sample of altered volcanic rock contained 1,500 parts per million copper (Richter and Matson, 1970 [OFR 70-276]). The volcanic rocks are intruded by small Tertiary porphyry dikes and stocks.

\section{Alteration:}

The host rocks to this deposit are highly altered but the type and extent of alteration have not been reported. The area is iron-stained.

\section{Age of mineralization:}

Tertiary? The mineralization may be related to the small Tertiary intrusives in the area.

\section{Deposit model:}

Quartz breccia with chalcopyrite 
Deposit model number (After Cox and Singer, 1986 or Bliss, 1992):

Production Status: None

Site Status: Inactive

Workings/exploration:

Production notes:

Reserves:

Additional comments:

The occurrence is in the Wrangell-St. Elias National Preserve.

References:

Richter and Matson, 1970 (OFR 70-276); Richter, 1973; Richter and others, 1975; Richter, 1976; Cobb and Richter, 1980.

Primary reference: Richter and others, 1975

Reporter(s): Travis L. Hudson (Applied Geology)

Last report date: $11 / 24 / 02$ 


\section{Site name(s): Unnamed (east of head of Nikonda Creek)}

Site type: Occurrence

\section{ARDF no.: NB054}

Latitude: 62.1100

Quadrangle: NB A-4

Longitude: 142.6822

\section{Location description and accuracy:}

This occurrence is about 2.3 miles east of the head of Nikonda Creek. It is at an elevation of about 7,400 feet, 3,500 feet southeast of peak 8701 in the SW1/4 of section 21, T. 4 N., R. 15 E. of the Copper River Meridian. This is locality 12 of Richter (1973), locality 33 of Richter and others (1975), and National Park Service locality WRST-48 (unpublished data). This locality is included as an 'Unnamed occurrence' by Cobb and Richter (1980). It is located to within a few hundred feet.

\section{Commodities:}

Main: $\mathrm{Ag}, \mathrm{Au}, \mathrm{Cu}, \mathrm{Pb}, \mathrm{Zn}$

\section{Other:}

Ore minerals: Chalcopyrite, galena, gold, sphalerite

Gangue minerals: Quartz

\section{Geologic description:}

This occurrence is a quartz vein with minor chalcopyrite, galena, and sphalerite; the vein cuts volcanic rocks of the upper Paleozoic Tetelna Volcanics (Richter, 1973; Richter and others, 1975; Richter, 1976). A sample of sulfide-bearing quartz contained 1 parts per million (ppm) gold, 30 ppm silver, 15,000 ppm copper, 15,000 ppm lead, and more than 10,000 ppm zinc (Richter and Matson, 1970 [OFR 70-276]).

\section{Alteration:}

\section{Age of mineralization:}

Cretaceous or Tertiary? Probably the same age as other base and precious metal deposits in the Nabesna A-4 quadrangle (for example NB043, NB045, and NB050).

\section{Deposit model:}

Polymetallic veins (Cox and Singer, 1986; model 22c)

Deposit model number (After Cox and Singer, 1986 or Bliss, 1992): 
$22 \mathrm{c}$

Production Status: None

Site Status: Inactive

Workings/exploration:

Production notes:

Reserves:

Additional comments:

The occurrence is in the Wrangell-St. Elias National Preserve.

\section{References:}

Richter and Matson, 1970 (OFR 70-276); Richter, 1973; Richter and others, 1975; Richter, 1976; Cobb and Richter, 1980.

Primary reference: Richter and others, 1975

Reporter(s): Travis L. Hudson (Applied Geology)

Last report date: $11 / 24 / 02$ 


\section{Site name(s): Unnamed (northeast of upper Cross Creek)}

Site type: Prospect

\section{ARDF no.: NB055}

Latitude: 62.0844

Quadrangle: NB A-4

Longitude: 142.5969

\section{Location description and accuracy:}

This prospect is on the north side of a glacial valley that is an unnamed north tributary to Cross Creek. It is at an elevation of about 6,600 feet, 6,000 feet southwest of peak 8233 , and 4,400 feet northwest of peak 7115. The prospect is near the center of the NW1/4 of section 36, T. 4 N., R. 15 E. of the Copper River Meridian. It is locality 16 of Richter (1973), locality 34 of Richter and others (1975), and National Park Service locality WRST-49 (unpublished data). Cobb and Richter (1980) included this prospect under the name 'Cross Cr.'. It is located to within a few hundred feet.

\section{Commodities:}

Main: $\mathrm{Ag}, \mathrm{Au}, \mathrm{Cu}, \mathrm{Pb}, \mathrm{Zn}$

\section{Other:}

Ore minerals: Chalcopyrite, galena, pyrite, sphalerite

Gangue minerals: Quartz

\section{Geologic description:}

This prospect was known as early as 1909 (Moffit and Knopf, 1909). It is a zone of intense hydrothermal alteration in upper Paleozoic volcanic rocks of the Tetelna Volcanics that contains fragments of volcanic rock cemented by quartz with minor pyrite, galena, sphalerite and chalcopyrite (Richter, 1973; Richter and others, 1975). A sample of a galena- and sphalerite-bearing, quartz vein from a strongly limonite-stained area contained 0.06 parts per million (ppm) gold, 50 ppm silver, 100 ppm copper, more than 10,000 ppm lead, and more than 10,000 ppm zinc (Richter and Matson, 1970 [OFR 70-276]). The limonite-stained alteration zone is 2,000 feet across and appears to be localized in the contact zone of a Tertiary porphyry complex that intrudes rocks of the upper Paleozoic Tetelna Volcanics (Richter, 1973, Richter, 1976).

\section{Alteration:}

The host rocks to this deposit are highly altered but the type and extent of alteration have not been reported. The area is iron-stained. 


\section{Age of mineralization:}

Tertiary. The alteration zone appears to be localized in the contact zone of a Tertiary porphyry complex with rocks of the upper Paleozoic Tetelna Volcanics (Richter, 1973; Richter, 1976).

\section{Deposit model:}

Polymetallic veins (Cox and Singer, 1986; model 22c)

\section{Deposit model number (After Cox and Singer, 1986 or Bliss, 1992):}

$22 \mathrm{c}$

\section{Production Status: None}

Site Status: Inactive

\section{Workings/exploration:}

This prospect was known as early as 1909 (Moffit and Knopf, 1909). There has been surface prospecting.

\section{Production notes:}

\section{Reserves:}

\section{Additional comments:}

The prospect is in the Wrangell-St. Elias National Preserve.

\section{References:}

Moffit and Knopf, 1909; Richter and Matson, 1970 (OFR 70-276); Richter, 1973; Richter and others, 1975; Richter, 1976; Cobb and Richter, 1980.

Primary reference: Richter and others, 1975

Reporter(s): Travis L. Hudson (Applied Geology)

Last report date: $11 / 24 / 02$ 


\section{Site name(s): Unnamed (west of upper Cross Creek)}

Site type: Occurrence

\section{ARDF no.: NB056}

Latitude: 62.0706

Quadrangle: NB A-4

Longitude: 142.5820

\section{Location description and accuracy:}

This occurrence is in a small unnamed drainage on the northwest side of the valley of Cross Creek. It is at an elevation of about 6,200 feet, 1,500 feet southeast of elevation 7115, and 4,500 feet west of Cross Creek. The occurrence is about 0.1 mile northeast of the center of section 1, T. 3 N., R. 15 E. of the Copper River Meridian. This is locality 17 of Richter (1973), locality 35 of Richter and others (1975), and National Park Service locality WRST-50 (unpublished data). Cobb and Richter (1980 [OFR 80-927]) included this locality as an 'Unnamed occurrence'. It is located to within a few hundred feet.

\section{Commodities:}

Main: $\mathrm{Au}, \mathrm{Cu}, \mathrm{Pb}, \mathrm{Zn}$

\section{Other:}

Ore minerals: Chalcopyrite, galena, gold, pyrite, sphalerite

Gangue minerals: Quartz

\section{Geologic description:}

This occurrence is a quartz vein that contains minor pyrite, chalcopyrite, galena, and sphalerite; it cuts hornfelsed volcanic country rock that has disseminated galena and sphalerite (Richter and Matson, 1970 [OFR 70-276]; Richter and others, 1975). A sample of a 20-foot-long quartz vein contained 0.8 parts per million (ppm) gold and a sample of volcanic hornfels with disseminated galena and sphalerite contained 0.9 ppm gold, 300 ppm copper, 3,000 ppm lead, and more than 10,000 ppm zinc (Richter and Matson, 1970 [OFR 70-276]). The volcanic host rocks are part of the upper Paleozoic, Tetelna Volcanics that form a roof pendant over a Tertiary porphyry complex (Richter, 1973, Richter, 1976).

\section{Alteration:}

Age of mineralization:

Tertiary? Mineralization is in a large metavolcanic roof pendant in a Tertiary porphyry complex (Richter, 1973; 1976). 


\section{Deposit model:}

Polymetallic veins (Cox and Singer, 1986; model 22c)

Deposit model number (After Cox and Singer, 1986 or Bliss, 1992):

$22 \mathrm{c}$

Production Status: None

Site Status: Inactive

Workings/exploration:

Probably only surface examination.

\section{Production notes:}

Reserves:

Additional comments:

The occurrence is in the Wrangell-St. Elias National Preserve.

\section{References:}

Richter and Matson, 1970 (OFR 70-276); Richter, 1973; Richter and others, 1975; Richter, 1976; Cobb and Richter, 1980.

Primary reference: Richter and Matson, 1970

Reporter(s): Travis L. Hudson (Applied Geology)

Last report date: $11 / 24 / 02$ 


\section{Site name(s): Unnamed (south of lower Monte Cristo Creek)}

Site type: Prospect

ARDF no.: NB057

Latitude: 62.2169

Quadrangle: NB A-4

Longitude: 142.9296

\section{Location description and accuracy:}

This occurrence is about 2,600 feet south of Monte Cristo Creek on the west side of the valley of the Nabesna River. It is at an elevation of about 3,100 feet and about 1,000 feet north-northeast of elevation 3450. The site is in the NW1/4 of section 13, T. 5 N., R. 13 E. of the Copper River Meridian. It is National Park Service locality WRST-22 (unpublished data) and the coordinates for this prospect were provided by the National Park Service.

\section{Commodities:}

Main: $\mathrm{Cu}$

Other:

Ore minerals:

\section{Gangue minerals:}

\section{Geologic description:}

An unpublished National Park Service map and accompanying database identify this locality as a copper porphyry prospect. It is in the southwestern part of the midCretaceous, Nabesna pluton near a porphyry stock inferred to be Tertiary in age (Richter, 1973).

\section{Alteration:}

Age of mineralization:

Cretaceous or Tertiary, the age of the host and nearby intrusive rocks.

\section{Deposit model:}

Porphyry Cu (Cox and Singer, 1986; model 18a)

Deposit model number (After Cox and Singer, 1986 or Bliss, 1992):

$18 \mathrm{a}$ 
Production Status: None

Site Status: Inactive

Workings/exploration:

Production notes:

Reserves:

Additional comments:

The prospect is in the Wrangell-St. Elias National Preserve.

\section{References:}

Richter, 1973.

Primary reference: This record

Reporter(s): Travis L. Hudson (Applied Geology)

Last report date: $11 / 24 / 02$ 


\section{Site name(s): Sheephead}

Site type: Prospect

ARDF no.: NB058

Latitude: 62.1703

Quadrangle: NB A-4

Longitude: 142.9346

\section{Location description and accuracy:}

This prospect is about 1,500 feet west of the lower Nabesna Glacier on the east flank of hill 4040. It is at an elevation of about 3,500 feet in the NW1/4 of section 36, T. 5 N., R. 13 E. of the Copper River Meridian. This is National Park Service locality WRST-25 (unpublished data) and the coordinates for this prospect were provided by the National Park Service.

\section{Commodities:}

Main: $\mathrm{Au}, \mathrm{Cu}, \mathrm{Fe}$

\section{Other:}

Ore minerals:

\section{Gangue minerals:}

\section{Geologic description:}

An unpublished National Park Service map and accompanying database identify this locality as a gold, copper, and iron prospect. One mining claim was located between 1959 and 1972. This prospect is in an area where porphyry dikes cut Triassic, Nikolai Greenstone (Richter, 1973). Massive magnetite with pyrite and some chalcopyrite occurs in Nikolai Greenstone about 1.5 miles to the south (NB040).

\section{Alteration:}

Age of mineralization:

Tertiary? Porphyry dikes in the area are inferred to be part of a Tertiary intrusive suite (Richter, 1973).

\section{Deposit model:}

Deposit model number (After Cox and Singer, 1986 or Bliss, 1992):

Production Status: None 
Site Status: Inactive

Workings/exploration:

Some surface prospecting has occurred here.

Production notes:

Reserves:

Additional comments:

The prospect is in the Wrangell-St. Elias National Preserve.

\section{References:}

Richter, 1973.

Primary reference: This record

Reporter(s): Travis L. Hudson (Applied Geology)

Last report date: $11 / 24 / 02$ 


\section{Site name(s): Unnamed (south of Orange Hill)}

Site type: Prospect

ARDF no.: NB059

Latitude: 62.1854

Quadrangle: NB A-4

Longitude: 142.8493

\section{Location description and accuracy:}

This prospect is near the mouth of Nikonda Creek, east of the terminus of Nabesna Glacier. It is at an elevation of about 3,000 feet, 5,500 feet south of Orange Hill, and 1,000 feet east of the glacier. The site is in the NE1/4 of section 29, T. 5 N., R. 14 E. of the Copper River Meridian. This is National Park Service locality WRST-30 (unpublished data) and the coordinates for this prospect were provided by the National Park Service.

\section{Commodities:}

Main: $\mathrm{Ag}, \mathrm{Cu}$

\section{Other:}

\section{Ore minerals:}

\section{Gangue minerals:}

\section{Geologic description:}

An unpublished National Park Service map and accompanying database identify this locality as a copper-silver porphyry prospect that was explored by a 15 -foot adit. It may be part of the Orange Hill porphyry-copper system (NB043) (Linn, 1973; Hollister and others, 1975; Richter and others, 1975). The Orange Hill deposit is in quartz diorite and granodiorite of the southwestern border zone of the mid-Cretaceous Nabesna pluton. The granitic rocks in turn are intruded by quartz-plagioclase porphyry that is also inferred to be Cretaceous in age (Richter, 1973). At this site, the prospect is within Paleozoic volcanic rocks in the contact zone to the Nabesna pluton (Richter, 1973).

\section{Alteration:}

This prospect may be in the chlorite, minor sericite, and anhydrite outer alteration zone of the Orange Hill deposit (NB043).

\section{Age of mineralization:}

Mid-Cretaceous? The prospect is in volcanic rocks in the contact zone of the midCretaceous Nabesna pluton (NB043). 
Deposit model:

Porphyry Cu-Mo (Cox and Singer, 1986; model 21a)

Deposit model number (After Cox and Singer, 1986 or Bliss, 1992):

$21 \mathrm{a}$

Production Status: None

Site Status: Inactive

Workings/exploration:

A 15 foot adit was driven at this prospect.

Production notes:

Reserves:

Additional comments:

The prospect is in the Wrangell-St. Elias National Preserve.

References:

Richter, 1973; Linn, 1973; Richter and others, 1975; Hollister and others, 1975.

Primary reference: This record

Reporter(s): Travis L. Hudson (Applied Geology)

Last report date: $11 / 24 / 02$ 


\section{Site name(s): Unnamed (lower Nikonda Creek)}

Site type: Prospect

ARDF no.: NB060

Latitude: 62.1803

Quadrangle: NB A-4

Longitude: 142.8361

\section{Location description and accuracy:}

This prospect is on lower Nikonda Creek, east of the terminus of Nabesna Glacier. It is at an elevation of about 3,050 feet, 7,500 feet south-southeast of Orange Hill, and 3,700 feet east of the glacier. The site is in the SW1/4 of section 28, T. 5 N., R. 14 E. of the Copper River Meridian. This is National Park Service locality WRST-32 (unpublished data) and the coordinates for this prospect were provided by the National Park Service.

\section{Commodities:}

Main: $\mathrm{Ag}, \mathrm{Cu}$

\section{Other:}

\section{Ore minerals:}

\section{Gangue minerals:}

\section{Geologic description:}

An unpublished National Park Service map and accompanying database identify this locality as a copper-silver porphyry prospect. It may be part of the Orange Hill porphyrycopper, mineralized system (NB043) (Linn, 1973; Hollister and others, 1975; Richter and others, 1975). The Orange Hill deposit is in quartz diorite and granodiorite of the southwestern border zone of the mid-Cretaceous Nabesna pluton. The granitic rocks in turn are intruded by quartz plagioclase porphyry that is also inferred to be Cretaceous in age (Richter, 1973). At this site, the prospect is in Paleozoic volcanic rocks in the contact zone to the Nabesna pluton (Richter, 1973).

\section{Alteration:}

This prospect may be in the chlorite, minor sericite, and anhydrite outer alteration zone of the Orange Hill deposit (NB043).

\section{Age of mineralization:}

Mid-Cretaceous? The prospect is in volcanic rocks in the contact zone of the midCretaceous Nabesna pluton (NB043). 


\section{Deposit model:}

Porphyry Cu-Mo (Cox and Singer, 1986; model 21a)

Deposit model number (After Cox and Singer, 1986 or Bliss, 1992):

$21 \mathrm{a}$

Production Status: None

Site Status: Inactive

\section{Workings/exploration:}

Surface prospecting has occurred in the area of this prospect.

\section{Production notes:}

Reserves:

\section{Additional comments:}

The prospect is in the Wrangell-St. Elias National Preserve.

\section{References:}

Richter, 1973; Linn, 1973; Richter and others, 1975; Hollister and others, 1975.

Primary reference: This record

Reporter(s): Travis L. Hudson (Applied Geology)

Last report date: $11 / 24 / 02$ 


\section{Site name(s): Gay}

Site type: Prospect

ARDF no.: NB061

Latitude: 62.1375

Quadrangle: NB A-4

Longitude: 142.9269

\section{Location description and accuracy:}

This prospect is along the west side of lower Nabesna Glacier. It is at an elevation of about 3,500 feet in the SW1/4 of section 7, T. 4 N., R. 14 E. of the Copper River Meridian. This is National Park Service locality WRST-28 (unpublished data) and the coordinates for this prospect were provided by the National Park Service.

\section{Commodities:}

Main: $\mathrm{Au}, \mathrm{Co}$

Other:

Ore minerals: Cobaltite?, gold

\section{Gangue minerals:}

\section{Geologic description:}

An unpublished National Park Service map and accompanying database identify this locality as a gold and cobalt prospect. Four mining claims were located here between 1972 and 1974 as the Gay 1-4 claims. These claims may have been on or may have included the calcite vein with gold and cobaltite at locality NB041. That vein is in highly altered and limonite-stained Triassic, Nikolai Greenstone(?) near the contact with a Tertiary porphyry intrusion (Richter, 1973).

\section{Alteration:}

Age of mineralization:

Tertiary? The age of the nearby porphyry is inferred to be Tertiary.

\section{Deposit model:}

Calcite vein with gold and cobaltite?

Deposit model number (After Cox and Singer, 1986 or Bliss, 1992):

Production Status: None 
Site Status: Inactive

Workings/exploration:

Some surface prospecting has occurred here.

Production notes:

Reserves:

Additional comments:

The prospect is in the Wrangell-St. Elias National Preserve.

\section{References:}

Richter, 1973.

Primary reference: This record

Reporter(s): Travis L. Hudson (Applied Geology)

Last report date: $11 / 24 / 02$ 


\section{Site name(s): Unnamed (east side of lower Nabesna Glacier)}

Site type: Occurrence

ARDF no.: NB062

Latitude: 62.0958

Quadrangle: NB A-4

Longitude: 142.8329

\section{Location description and accuracy:}

This occurrence is on the lower, west flank of the large ridge east of lower Nabesna Glacier. It is at an elevation of about 3,700 feet, 1,000 feet east of the glacier, and 1 mile southwest of peak 5901. The site is in the SW1/4 of section 27, T. 4 N., R. 14 E. of the Copper River Meridian. This is National Park Service locality WRST-51 (unpublished data) and the coordinates for this occurrence were provided by the National Park Service.

\section{Commodities:}

Main: $\mathrm{Cu}, \mathrm{Zn}$

Other:

Ore minerals:

Gangue minerals:

Geologic description:

An unpublished National Park Service map and accompanying database identify this locality as a copper and zinc occurrence. The bedrock in this area is dominantly Permian to Triassic argillite (Richter, 1973).

\section{Alteration:}

Age of mineralization:

Deposit model:

Deposit model number (After Cox and Singer, 1986 or Bliss, 1992):

Production Status: None

Site Status: Inactive

Workings/exploration: 
Production notes:

Reserves:

Additional comments:

The occurrence is in the Wrangell-St. Elias National Preserve.

References:

Richter, 1973.

Primary reference: This record

Reporter(s): Travis L. Hudson (Applied Geology)

Last report date: $11 / 24 / 02$ 


\section{Site name(s): Unnamed (east of lower Nabesna Glacier)}

Site type: Occurrence

ARDF no.: NB063

Latitude: 62.1011

Quadrangle: NB A-4

Longitude: 142.8013

\section{Location description and accuracy:}

This prospect is on west flank of the ridge east of Nabesna Glacier. It is at an elevation of about 5,900 feet, about 3,200 feet west-southwest of peak 7445. This locality was identified on an unpublished National Park Service map as locality WRST-45 but the accompanying data for this occurrence are for the Orange Hill prospect (NB043 and NB044). This is assumed to be a valid occurrence but no other information is available.

\section{Commodities:}

\section{Main:}

Other:

\section{Ore minerals:}

Gangue minerals:

\section{Geologic description:}

This locality was identified on an unpublished National Park Service map as locality WRST-45 but the accompanying data for this locality are for the Orange Hill prospect (NB043 and NB044). This is assumed to be a valid occurrence but no other information is available. The location is near the south contact of a Tertiary porphyry stock and Triassic, Nikolai Greenstone (Richter, 1973).

\section{Alteration:}

Age of mineralization:

\section{Deposit model:}

Deposit model number (After Cox and Singer, 1986 or Bliss, 1992):

Production Status: None

Site Status: Inactive 
Workings/exploration:

Production notes:

Reserves:

Additional comments:

The occurrence is in the Wrangell-St. Elias National Preserve.

References:

Richter, 1973.

Primary reference: This record

Reporter(s): Travis L. Hudson (Applied Geology)

Last report date: $11 / 24 / 02$ 


\section{Site name(s): Unnamed (east side of Nabesna Glacier)}

Site type: Prospect

ARDF no.: NB064

Latitude: 62.0073

Quadrangle: NB A-4

Longitude: 142.8838

\section{Location description and accuracy:}

This prospect is on the nose of a north-trending ridge between Nabesna Glacier and an unnamed glacial valley to the east. It is near elevation 4804 and about 3,500 feet east of Nabesna Glacier. The site is at the approximate midpoint of the south boundary of section 29, T. 3 N., R. 14 E. of the Copper River Meridian. This is National Park Service locality WRST-46 (unpublished data) and the coordinates for this prospect were provided by the National Park Service.

\section{Commodities:}

Main: $\mathrm{Cu}$

Other:

Ore minerals:

Gangue minerals:

Geologic description:

An unpublished National Park Service map and accompanying database identify this locality as a volcanogenic copper prospect. The bedrock in this area is volcanic rocks of the Tertiary and Quaternary, Wrangell Lava (Richter, 1973).

\section{Alteration:}

Age of mineralization:

Quaternary or Tertiary? If the prospect is related to the Wrangell Lava, it is Tertiary or Quaternary in age.

\section{Deposit model:}

Deposit model number (After Cox and Singer, 1986 or Bliss, 1992):

Production Status: None 
Site Status: Inactive

Workings/exploration:

Some surface prospecting may have occurred at this locality.

Production notes:

\section{Reserves:}

Additional comments:

The prospect is in the Wrangell-St. Elias National Preserve.

\section{References:}

Richter, 1973.

Primary reference: This record

Reporter(s): Travis L. Hudson (Applied Geology)

Last report date: $11 / 24 / 02$ 


\section{Site name(s): Nike}

Site type: Prospect

ARDF no.: NB065

Latitude: 62.2189

Quadrangle: NB A-4

Longitude: 142.7603

\section{Location description and accuracy:}

This prospect is on the west fork of Bond Creek. It is at an elevation of about 3,900 feet, 6,600 feet northeast of peak 752, and 5,500 feet northwest of elevation 6805. The site is in the NE1/4 of section 14, T. 5 N., R. 14 E. of the Copper River Meridian. This is National Park Service locality WRST-33 (unpublished data) and the coordinates for this prospect were provided by the National Park Service.

\section{Commodities:}

Main: $\mathrm{Ag}, \mathrm{Cu}$

\section{Other:}

\section{Ore minerals:}

\section{Gangue minerals:}

\section{Geologic description:}

An unpublished National Park Service map and accompanying database identify this locality as a copper-silver porphyry prospect. Eleven mining claims were once located here and there are numerous surface diggings and short shafts. The bedrock in this area is dominantly granitic rocks of the mid-Cretaceous Nabesna pluton (Richter, 1973). This pluton is locally intruded by dikes, small irregular bodies, and stocks of hornblendeplagioclase porphyry. This porphyry is considered to be Tertiary in age (Richter, 1973).

\section{Alteration:}

Hydrothermal alteration like that at other porphyry copper prospects in the area (e.g. NB043) may be present.

\section{Age of mineralization:}

Mid-Cretaceous? K/Ar ages for the Nabesna pluton range from 105 +/- 4.0 to 114 +/3.4 Ma (Richter and others, 1975; Richter, Lanphere, and Matson, 1975). Many varieties of hornblende-plagioclase porphyry form irregular intrusive bodies into the Nabesna pluton and other regional bedrock units in the area; the porphyry is considered to be Tertiary in age (Richter, 1973). 


\section{Deposit model:}

Porphyry Cu-Mo (Cox and Singer, 1986; model 21a)

Deposit model number (After Cox and Singer, 1986 or Bliss, 1992):

$21 \mathrm{a}$

Production Status: None

Site Status: Inactive

\section{Workings/exploration:}

Eleven mining claims were once located here and there are numerous surface diggings and short shafts.

\section{Production notes:}

\section{Reserves:}

Additional comments:

The prospect is in the Wrangell-St. Elias National Preserve.

\section{References:}

Richter, 1973; Richter and others, 1975; Richter, Lanphere, and Matson, 1975.

Primary reference: This record

Reporter(s): Travis L. Hudson (Applied Geology)

Last report date: $11 / 24 / 02$ 
Site name(s): Neil

Site type: Prospect

ARDF no.: NB066

Latitude: 62.2272

Quadrangle: NB A-4

Longitude: 142.7283

\section{Location description and accuracy:}

This prospect is on the northeast flank of the ridge between the west and middle forks of Bond Creek. It is at an elevation of about 4,800 feet, about 2,000 feet south of the junction of the middle and east forks of Bond Creek. The site is near the center of section 12, T. 5 N., R. 14 E. of the Copper River Meridian. This is National Park Service locality WRST-36 (unpublished data) and the coordinates for this prospect were provided by the National Park Service.

\section{Commodities:}

Main: $\mathrm{Cu}$

\section{Other:}

\section{Ore minerals:}

\section{Gangue minerals:}

\section{Geologic description:}

An unpublished National Park Service map and accompanying database identify this locality as a copper prospect. The bedrock in this area is dominantly granitic rocks of the mid-Cretaceous Nabesna pluton (Richter, 1973). This pluton is locally intruded by dikes, small irregular bodies, and stocks of hornblende-plagioclase porphyry. This porphyry is considered to be Tertiary in age (Richter, 1973).

\section{Alteration:}

\section{Age of mineralization:}

Mid-Cretaceous? K/Ar ages for the Nabesna pluton range from $105+/$ - 4.0 to 114 +/3.4 Ma (Richter and others, 1975; Richter, Lanphere, and Matson, 1975). Many varieties of hornblende-plagioclase porphyry form irregular intrusive bodies into the Nabesna pluton and other regional bedrock units in the area; the porphyry is considered to be Tertiary in age (Richter, 1973).

\section{Deposit model:}


Porphyry Cu-Mo? (Cox and Singer, 1986; model 21a)

Deposit model number (After Cox and Singer, 1986 or Bliss, 1992): $21 \mathrm{a}$ ?

Production Status: None

Site Status: Inactive

Workings/exploration:

Some surface prospecting probably occurred here.

Production notes:

Reserves:

Additional comments:

The prospect is in the Wrangell-St. Elias National Preserve.

\section{References:}

Richter, 1973; Richter and others, 1975; Richter, Lanphere, and Matson, 1975.

Primary reference: This record

Reporter(s): Travis L. Hudson (Applied Geology)

Last report date: $11 / 24 / 02$ 


\section{Site name(s): Nabob}

Site type: Prospect

ARDF no.: NB067

Latitude: 62.1916

Quadrangle: NB A-4

Longitude: 142.5048

\section{Location description and accuracy:}

This prospect is about 2,500 feet downstream of the terminus of the glacier at the head of William Creek. This is close to the east boundary of the Nabesna A-4 quadrangle in the SE1/4 of section 19, T. 5 N., R. 16 E. of the Copper River Meridian. This is National Park Service locality WRST-41 (unpublished data) and the coordinates of this prospect were provided by the National Park Service.

\section{Commodities:}

Main: $\mathrm{Au}, \mathrm{Cu}$

\section{Other:}

\section{Ore minerals:}

\section{Gangue minerals:}

\section{Geologic description:}

An unpublished National Park Service map and accompanying database identify this as a copper-gold prospect, where 8 lode claims were active from 1972 to 1976 . It is near the contact between granitic rocks of the mid-Cretaceous, Nabesna pluton and Triassic, Nikolai Greenstone (Richter, 1973). A sample of garnet skarn collected about 1 mile south of the site and just inside the boundary of the Nabesna A-3 quadrangle contained 1.2 parts per million (ppm) gold, 10 ppm silver, more than 20,000 ppm copper, and 1,500 ppm nickel (Richter and Matson, 1969).

\section{Alteration:}

\section{Age of mineralization:}

Mid-Cretaceous? If this deposit is related to emplacement of the Nabesna pluton, it is mid-Cretaceous in age; K/Ar dates for this pluton range from $105+/-4.0$ to $114+/-3.4$ Ma (Richter, Lanphere, and Matson, 1975).

\section{Deposit model:}


Deposit model number (After Cox and Singer, 1986 or Bliss, 1992):

Production Status: None

Site Status: Inactive

Workings/exploration:

At least surface prospecting has occurred here.

Production notes:

Reserves:

Additional comments:

The prospect is in the Wrangell-St. Elias National Preserve.

\section{References:}

Richter and Matson, 1969; Richter, 1973; Richter, Lanphere, and Matson, 1975.

Primary reference: This record

Reporter(s): Travis L. Hudson (Applied Geology)

Last report date: $11 / 24 / 02$ 


\section{Site name(s): Unnamed (south of William Creek)}

Site type: Occurrence

ARDF no.: NB068

Latitude: 62.1985

Quadrangle: NB A-3

Longitude: 142.4428

\section{Location description and accuracy:}

This occurrence is on the north flank of the large ridge bordering the south side of the valley of William and Notch Creeks. It is at an elevation of about 6,100 feet, 7,500 feet north-northwest of peak 8750, and 5,700 feet south of William Creek. The occurrence is about 0.5 mile east-southwest of the center of section 21, T. 5 N., R. 16 E. of the Copper River Meridian. It is sample locality 329 of Richter and Matson (1969) and is located to within a few hundred feet.

\section{Commodities:}

Main: $\mathrm{Cu}$

\section{Other:}

Ore minerals: Azurite, malachite

\section{Gangue minerals:}

\section{Geologic description:}

This is an occurrence of secondary copper minerals localized in a breccia at the contact between granodiorite and Triassic limestone (Richter and Matson, 1969). A chip sample across 1.5 feet of the copper-stained breccia contained 2 parts per million (ppm) gold, 700 ppm boron, 7,000 ppm copper, and 700 ppm zinc. The granodiorite is along the southeast contact of the mid-Cretaceous Nabesna pluton (Richter, 1971 [I-655]; Richter, 1973; Richter, Lanphere, and Matson, 1975).

\section{Alteration:}

Oxidation has produced secondary copper minerals.

\section{Age of mineralization:}

Mid-Cretaceous? May be related to emplacement of the Nabesna pluton. K/Ar ages for the Nabesna pluton range from $105+/-4.0$ to 114 +/- 3.4 Ma (Richter, Lanphere, and Matson, 1975).

\section{Deposit model:}


Contact metamorphic polymetallic deposit?

Deposit model number (After Cox and Singer, 1986 or Bliss, 1992):

Production Status: None

Site Status: Inactive

Workings/exploration:

Probably only surface examination.

\section{Production notes:}

\section{Reserves:}

\section{Additional comments:}

The occurrence is in the Wrangell-St. Elias National Preserve.

\section{References:}

Richter and Matson, 1969; Richter, 1971 (I-655); Richter, 1973; Richter, Lanphere, and Matson, 1975.

Primary reference: Richter and Matson, 1969

Reporter(s): Travis L. Hudson (Applied Geology)

Last report date: $11 / 24 / 02$ 


\section{Site name(s): Unnamed (south of Williams Creek)}

Site type: Occurrence

ARDF no.: NB069

Latitude: 62.1824

Quadrangle: NB A-3

Longitude: 142.4105

\section{Location description and accuracy:}

This occurrence is on the north flank of the large ridge bordering the south side of the valley of William and Notch Creeks. It is at an elevation of about 6,900 feet, 4,500 feet northeast of peak 8750 and 5,500 feet northwest of peak 7351. The occurrence is about 0.5 mile east-southeast of the center of section 27, T. 5 N., R. 16 E. of the Copper River Meridian. The occurrence is located to within about 1,000 feet.

\section{Commodities:}

Main: Gypsum (alabaster)

\section{Other:}

Ore minerals: Gypsum

Gangue minerals:

\section{Geologic description:}

Massive pods up to 5 feet thick of the alabaster, a variety of gypsum, occur in amphibolitized, amygdaloidal basalt of the Triassic, Nikolai Greenstone (Richter and Matson, 1969; Richter, 1971 [I-655]; Richter, 1976).

\section{Alteration:}

Gypsum replacement of metabasalt.

Age of mineralization:

Cretaceous? Alteration and mineralization of the Nikolai Greenstone is thought to have accompanied regional deformation and low-grade metamorphism in the Late Jurassic to Early Cretaceous (MacKevett and others, 1997).

\section{Deposit model:}

Deposit model number (After Cox and Singer, 1986 or Bliss, 1992):

Production Status: None 
Site Status: Inactive

Workings/exploration:

Production notes:

\section{Reserves:}

Additional comments:

The occurrence is in the Wrangell-St. Elias National Preserve.

\section{References:}

Richter and Matson, 1969; Richter, 1971 (I-655); Richter, 1976; MacKevett and others, 1997.

Primary reference: Richter and Matson, 1969

Reporter(s): Travis L. Hudson (Applied Geology)

Last report date: $11 / 24 / 02$ 


\section{Site name(s): Unnamed (west of lower Ramshole Creek)}

Site type: Occurrence

ARDF no.: NB070

Latitude: 62.1225

Quadrangle: NB A-3

Longitude: 142.3533

\section{Location description and accuracy:}

This occurrence is on the nose of the ridge along the west side of lower Ramshole Creek. It is at an elevation about 5,500 feet, 2,200 feet west of Ramshole Creek. The occurrence is in the SW1/4 of section 17, T. 4 N., R. 17 E. of the Copper River Meridian. This record includes National Park Service locality WRST-52 (unpublished data) which is approximately located on Ramshole Creek. This occurrence is probably located to within several thousand feet.

\section{Commodities:}

Main: $\mathrm{Au}, \mathrm{Ba}$

Other:

Ore minerals: Barite, gold

\section{Gangue minerals:}

\section{Geologic description:}

Richter and Matson (1969) found massive, dark- gray barite float at this site; the float is probably nearly in place. National Park Service locality WRST-52 (unpublished data) is identified as a gold prospect here or near here. Bedrock in the area is siliciclastic sedimentary rocks of the Permian Eagle Creek Formation (Richter, 1976). Triassic gabbro intrusions are common in this formation and locally make up to 70 percent of the section (Richter, 1971 [I-655]).

\section{Alteration:}

Age of mineralization:

Permian? May be the age of the host sedimentary rocks.

\section{Deposit model:}

Stratiform or vein barite?

Deposit model number (After Cox and Singer, 1986 or Bliss, 1992): 
Production Status: None

Site Status: Inactive

Workings/exploration:

Probably only surface examination.

Production notes:

Reserves:

Additional comments:

The occurrence is in the Wrangell-St. Elias National Preserve.

\section{References:}

Richter and Matson, 1969; Richter, 1971 (I-655); Richter, 1976.

Primary reference: Richter and Matson, 1969

Reporter(s): Travis L. Hudson (Applied Geology)

Last report date: $11 / 24 / 02$ 


\section{Site name(s): Dark Moon}

Site type: Prospect

ARDF no.: NB071

Latitude: 62.0413

Quadrangle: NB A-3

Longitude: 142.1462

\section{Location description and accuracy:}

This prospect is on the nose of a low ridge on the west side of upper Chisana River valley. It is at an elevation of 4,000 feet, 1.7 miles southeast of the summit of Euchre Mountain, and 3.5 miles southwest of Chisana. The prospect is near the southeast corner of the NE1/4 of section 17, T. 3 N., R. 18 E. of the Copper River Meridian. This is National Park Service locality WRST-66 (unpublished data) and the coordinates of this prospect were provided by the National Park Service.

\section{Commodities:}

Main: $\mathrm{Au}$

Other:

Ore minerals: Gold

Gangue minerals:

\section{Geologic description:}

An unpublished National Park Service map and accompanying database identify this as a gold prospect and claims were apparently staked at one time (U. S. Bureau of Mines, 1994). It is in an area of Quaternary landslide deposits (Richter, 1971 [I-655]).

\section{Alteration:}

Age of mineralization:

Quaternary?

\section{Deposit model:}

Placer Au? (Cox and Singer, 19876; model 39a)

Deposit model number (After Cox and Singer, 1986 or Bliss, 1992): 39a?

Production Status: Undetermined. 
Site Status: Inactive

Workings/exploration:

Production notes:

\section{Reserves:}

Additional comments:

The prospect is in the Wrangell-St. Elias National Preserve.

\section{References:}

Richter, 1971 (I-655); U. S. Bureau of Mines, 1994.

Primary reference: This record

Reporter(s): Travis L. Hudson (Applied Geology)

Last report date: $11 / 24 / 02$ 


\section{Site name(s): Notch Creek}

Site type: Prospect

ARDF no.: NB072

Latitude: 62.1786

Quadrangle: NB A-3

Longitude: 142.3388

\section{Location description and accuracy:}

This occurrence is on the south side of the valley of Notch Creek valley at an elevation of about 4,400 feet. It is 1.6 miles east of elevation 5850 and 2.2 miles northeast of elevation 7351. The prospect is about 0.4 mile south of the center of section 30, T. 5 N., R. 17 E. of the Copper River Meridian. This is National Park Service locality WRST-53 (unpublished data) and the coordinates for this prospect were provided by the National Park Service.

\section{Commodities:}

Main: $\mathrm{Au}$

Other:

Ore minerals: Gold

\section{Gangue minerals:}

\section{Geologic description:}

An unpublished National Park Service map and accompanying database identify this as a placer gold prospect that was active as early as 1917. Richter and Matson (1969) show attempted placer mine workings within 3,000 feet of the map site. Richter (1971 [I-655]) shows the area to be one underlain by glacial outwash deposits and younger alluvial fans.

\section{Alteration:}

Age of mineralization:

Quaternary.

\section{Deposit model:}

Placer Au (Cox and Singer, 1986; model 39a)

Deposit model number (After Cox and Singer, 1986 or Bliss, 1992):

$39 a$ 
Production Status: Undetermined.

Site Status: Inactive

Workings/exploration:

Some surface placer workings are present.

\section{Production notes:}

\section{Reserves:}

\section{Additional comments:}

The prospect is in the Wrangell-St. Elias National Preserve.

\section{References:}

Richter and Matson, 1969 (OFR 69-223); Richter, 1971 (I-655).

Primary reference: This record

Reporter(s): Travis L. Hudson (Applied Geology)

Last report date: $11 / 24 / 02$ 


\section{Site name(s): Big Eldorado Creek}

Site type: Mine

ARDF no.: NB073

Latitude: 62.1096

Quadrangle: NB A-2

Longitude: 141.9495

\section{Location description and accuracy:}

This placer gold mine is on Big Eldorado Creek, a drainage on the west flank of Gold Hill. The site is the approximate midpoint of the 2,500 feet of placer workings mapped by Richter and Jones (1973 ). It is in the SW1/4 of section 21, T. 4 N., R. 19 E. of the Copper River Meridian. This is locality 64 of Richter and others (1975) and it is included in National Park Service locality WRST-59 (unpublished data). Cobb and Richter (1980) included this mine under the name 'Big Eldorado Cr.' It is accurately located.

\section{Commodities:}

Main: $\mathrm{Au}$

\section{Other:}

Ore minerals: Gold

\section{Gangue minerals:}

\section{Geologic description:}

Coarse, bright and rough gold was mined from this placer deposit on the northwest flank of Gold Hill as early as 1915 (Capps, 1915; 1916). The gravels were up to 10 feet thick but two placer workings described by Capps (1915) had dimensions of 600 feet by 12 feet in 6 feet of gravel, and 250 feet by 30 feet in 2 feet of gravel. Placer gold was also mined from the top 2 to 4 feet of fractured bedrock and some of the ground was frozen. This placer is unique in the area because it is probably a primary concentration of placer gold. All other placers in the district are probably derived from reworked Quaternary deposits (Richter and others, 1975). Bedrock in Big Eldorado Creek varies from clinopyroxene diorite to monzonite of the mid-Cretaceous Chisana pluton (Richter and Jones, 1973; Richter, Lanphere, and Matson, 1975).

\section{Alteration:}

Age of mineralization:

Holocene. 


\section{Deposit model:}

Placer Au (Cox and Singer, 1986; model 39a)

Deposit model number (After Cox and Singer, 1986 or Bliss, 1992):

$39 \mathrm{a}$

Production Status: Yes; small

Site Status: Inactive

Workings/exploration:

Surface placer mine workings are present along about 3,000 feet of Big Eldorado Creek (Richter and Jones, 1973).

\section{Production notes:}

Assuming a price of $\$ 20.00$ per ounce, about 50,000 ounces of gold were produced from placers in the Chisana area (Richter and others, 1975). Most of this production was from the Gold Run (NB077) and Bonanza Creek (NB079) drainages, and about half was produced between 1913 and 1915; some mining continued in the area up to the 1970s.

\section{Reserves:}

\section{Additional comments:}

The mine is in the Wrangell-St. Elias National Preserve.

\section{References:}

Capps, 1915; Capps, 1916; Richter and Jones, 1973; Richter and others, 1975; Richter, Lanphere, and Matson, 1975; Cobb and Richter, 1980.

Primary reference: Capps, 1915

Reporter(s): Travis L. Hudson (Applied Geology)

Last report date: $11 / 24 / 02$ 


\section{Site name(s): Unnamed (east side of Big Eldorado Creek)}

Site type: Prospect

ARDF no.: NB074

Latitude: 62.1057

Quadrangle: NB A-2

Longitude: 141.9405

\section{Location description and accuracy:}

This prospect is at an elevation of about 4,850 feet on the east side of Big Eldorado Creek, a drainage on the west flank of Gold Hill. It is 6,500 feet west-northwest of the summit of Gold Hill. The prospect is near the center of the south boundary of section 21, T. 4 N., R. 19 E. of the Copper River Meridian. This is locality 38 of Richter and others (1975) and it is included in National Park Service locality WRST-59 (unpublished data). Cobb and Richter (1980) included this prospect under the name 'Big Eldorado (lode)'. It is located to within a few hundred feet.

\section{Commodities:}

Main: $\mathrm{Au}, \mathrm{Cu}$

Other:

Ore minerals: Chalcopyrite, gold, pyrite

Gangue minerals: Quartz

\section{Geologic description:}

A quartz vein that contains pyrite, chalcopyrite, and gold cuts syenodiorite of the Chisana pluton at this prospect (Richter and others, 1975). The site is on the west flank of Gold Hill where the Chisana pluton is in contact with Cretaceous volcanic and volcaniclastic rocks (Richter and Jones, 1973). The Chisana pluton varies from clinopyroxene diorite to monzonite and has a K/Ar age of $110+/-3.0 \mathrm{Ma}$ (Richter, Lanphere and Matson, 1975).

\section{Alteration:}

Age of mineralization:

Probably related to Mid-Cretaceous? pluton; the vein is in the Chisana pluton which has has a K/Ar age of 110 +/- 3.0 Ma (Richter, Lanphere, and Matson, 1975).

\section{Deposit model:}

Polymetallic vein? (Cox and Singer, 1986; model 22c) 
Deposit model number (After Cox and Singer, 1986 or Bliss, 1992):

$22 \mathrm{c}$ ?

Production Status: None

Site Status: Inactive

Workings/exploration:

Some surface exploration took place at this prospect after 1967.

Production notes:

Reserves:

Additional comments:

The prospect is in the Wrangell-St. Elias National Preserve.

\section{References:}

Richter and Jones, 1973; Richter and others, 1975; Richter, Lanphere, and Matson, 1975;

Cobb and Richter, 1980.

Primary reference: Richter and others, 1975

Reporter(s): Travis L. Hudson (Applied Geology)

Last report date: $11 / 24 / 02$ 


\section{Site name(s): Erie}

Site type: Prospect

ARDF no.: NB075

Latitude: 62.0809

Quadrangle: NB A-2

Longitude: 141.8674

\section{Location description and accuracy:}

This prospect is on lower Bonanza Creek about 2,000 feet upstream of its mouth. The site is in the SE1/4 of section 35, T. 4 N., R. 19 E. of the Copper River Meridian. This is locality 42 of Richter and others (1975) and the site is included in National Park Service locality WRST-62 (unpublished data). Cobb and Richter (1980) included this prospect under the name 'Erie'. It is located to within a few hundred feet.

\section{Commodities:}

Main: $\mathrm{Ag}, \mathrm{Au}, \mathrm{Pb}$

\section{Other:}

Ore minerals: Galena, gold, pyrite

Gangue minerals: Quartz

\section{Geologic description:}

At this prospect, Cretaceous volcanic and volcaniclastic rocks contain disseminated pyrite; the rocks are locally cut by pyrite-bearing dikes (Moffit, 1943; Richter and Jones, 1973). Small pyrite and quartz veins in volcanic rock and in a dike that strikes N $20 \mathrm{~W}$ and dips $75 \mathrm{~N}$ contain free gold and galena with up to 22 ounces silver per ton (Capps, 1916). A grab sample of massive, green fragmental volcanic rock contained 1,500 parts per million (ppm) copper and 500 ppm lead (Richter and Matson, 1970 [OFR 70-275]). Short adits have been driven to explore this prospect. This mineralized zone is on the southeast flank of Gold Hill, where intrusive rocks of the Chisana pluton intrude volcanic rocks of the Cretaceous, Chisana Formation.

\section{Alteration:}

Disseminated pyrite and quartz-sulfide veining. Oxidation has produced iron-staining.

\section{Age of mineralization:}

Mid-Cretaceous? The deposit may be related to emplacement of the Chisana pluton which has a K/Ar age of 110 +/- 3.0 Ma (Richter, Lanphere, and Matson, 1975). 


\section{Deposit model:}

Polymetallic veins? (Cox and Singer,1986; model 22c)

Deposit model number (After Cox and Singer, 1986 or Bliss, 1992): $22 \mathrm{c}$ ?

Production Status: Undetermined.

Site Status: Inactive

Workings/exploration:

This altered and mineralized zone has been explored by surface prospecting and short adits.

\section{Production notes:}

Reserves:

Additional comments:

The prospect is in the Wrangell-St. Elias National Preserve.

\section{References:}

Capps, 1916; Moffit, 1943; Richter and Matson, 1970 (OFR 70-275); Richter and Jones, 1973; Richter and others, 1975; Richter, Lanphere, and Matson, 1975; Cobb and Richter, 1980.

Primary reference: Moffitt, 1943

Reporter(s): Travis L. Hudson (Applied Geology)

Last report date: $11 / 24 / 02$ 


\section{Site name(s): Bryan Creek}

Site type: Mine

ARDF no.: NB076

Latitude: 62.0345

Quadrangle: NB A-2

Longitude: 141.9450

\section{Location description and accuracy:}

This placer gold mine is on lower Bryan Creek, 2,500 feet northwest of hill 4615 and 6,500 feet southwest of peak 6075. The site is the approximate midpoint of 3,000 feet of placer workings outlined by Richter and Jones (1973). It is in the SW1/4 of section 16, T. 3 N., R. 19 E. of the Copper River Meridian. Cobb and Richter (1980) include this mine under the name 'Bryan Cr.'. This is locality 68 of Richter and others (1975) and National Park Service locality WRST-70 (unpublished data).

\section{Commodities:}

Main: $\mathrm{Au}, \mathrm{Cu}$

Other:

Ore minerals: Gold, native copper

\section{Gangue minerals:}

\section{Geologic description:}

Richter and Jones (1973) show placer mine workings along about 2,500 feet of Bryan Creek. The creek was prospected in 1914 and is characterized by abundant native copper nuggets with the placer gold (Capps, 1916). The placer deposit is at least partly on a clay false bedrock. Bedrock exposed along the channel of Bryan Creek is Cretaceous volcanic and volcaniclastic rocks (Richter and Jones, 1973).

\section{Alteration:}

Age of mineralization:

Quaternary.

\section{Deposit model:}

Placer Au (Cox and Singer, 1986; model 39a)

Deposit model number (After Cox and Singer, 1986 or Bliss, 1992): $39 \mathrm{a}$ 
Production Status: Yes; small

Site Status: Inactive

Workings/exploration:

Richter and Jones (1973) show placer mine workings along about 2,500 feet of Bryan Creek.

Production notes:

Reserves:

Additional comments:

The mine is in the Wrangell-St. Elias National Preserve.

References:

Capps, 1916; Richter and Jones, 1973; Richter and others, 1975; Cobb and Richter, 1980.

Primary reference: Capps, 1916

Reporter(s): Travis L. Hudson (Applied Geology)

Last report date: $11 / 24 / 02$ 


\title{
Site name(s): Gold Run Creek; Poorman Creek
}

Site type: Mine

\author{
ARDF no.: NB077
}

Latitude: 62.1159

Quadrangle: NB A-2

Longitude: 141.8929

\section{Location description and accuracy:}

About 1.4 miles of Gold Run Creek upstream of its confluence with Glacier Creek has been placer mined for gold. Poorman Creek, a headwater tributary to Gold Run Creek, has also been placer mined over most of its 1 mile length. This site is plotted at the junction of Poorman and Gold Run Creeks. It is near the northwest corner of section 23, T. 4 N., R. 19 E. of the Copper River Meridian. This is locality 63 of Richter and others (1975) and National Park Service locality WRST-69 (unpublished data). Cobb and Richter (1980) include this mine under the name 'Gold Run Cr.'. It is accurately located.

\section{Commodities:}

Main: $\mathrm{Au}$

\section{Other:}

Ore minerals: Gold

\section{Gangue minerals:}

\section{Geologic description:}

About 1.4 miles of Gold Run Creek upstream of its confluence with Glacier Creek has been placer mined for gold. Poorman Creek, a headwater tributary to Gold Run Creek, has also been placer mined over most of its 1 mile length (Richter and Jones, 1973). These placers were discovered in 1913 and mining took place intermittently to after WW II. Early placer workings described by Capps $(1915,1916)$ include a 150 - by 15 -foot area where gravels were 4.5 to 5 feet thick and a 500- by 40-foot area of frozen gravels that were 11 to 15 feet thick. The top 1 to 4 feet of fractured bedrock was also sluiced and some of the gold in it was coarse and round. The auriferous gravels contain subrounded, shale and graywacke clasts and some well-rounded, lava and diorite clasts. The lava and diorite clasts in the stream gravels may have been derived from Quaternary or Tertiary gravels capping Gold Hill in the headwaters of this drainage (Richter and Jones, 1973). The Quaternary or Tertiary gravels on Gold Hill are reported to be gold-bearing (Moffit, 1954). Bedrock is only locally exposed in the channel of this drainage. It includes Jurassic or Cretaceous siliciclastic rocks and small intrusive dikes or plugs. Most of the creek reworks various Quaternary surficial deposits (Richter and Jones, 1973). At Gold Hill, 
the Chisana pluton intrudes Cretaceous volcanic and volcaniclastic rocks and this placer is one of several developed within or peripheral to the Chisana pluton (Richter and Jones, 1973; Richter and others, 1975).

\section{Alteration:}

Age of mineralization:

Quaternary.

\section{Deposit model:}

Placer Au (Cox and Singer, 1986; model 39a)

Deposit model number (After Cox and Singer, 1986 or Bliss, 1992):

$39 \mathrm{a}$

Production Status: Yes; small

Site Status: Inactive

\section{Workings/exploration:}

About 1.4 miles of Gold Run Creek upstream of its confluence with Glacier Creek has been placer mined for gold. Poorman Creek, a headwater tributary to Gold Run Creek, has also been placer mined over most of its 1 mile length (Richter and Jones, 1973). These placers were discovered in 1913 and mining took place intermittently until after WW II.

\section{Production notes:}

Assuming a price of $\$ 20.00$ per ounce, about 50,000 ounces of gold were recovered from placers in the Chisana area (Richter and others, 1975). Most of this production was from the Gold Run (this site) and Bonanza Creek (NB079) drainages and about half was produced between 1913 and 1915; some mining continued in the area up to the 1970s.

\section{Reserves:}

\section{Additional comments:}

The mine is in the Wrangell-St. Elias National Preserve.

\section{References:}

Capps, 1915; Capps, 1916; Moffit, 1954; Richter and Jones, 1973; Richter and others, 1975; Cobb and Richter, 1980.

Primary reference: Capps, 1916

Reporter(s): Travis L. Hudson (Applied Geology)

Last report date: $11 / 24 / 02$ 


\section{Site name(s): Unnamed (head of Snow Gulch)}

Site type: Occurrence

ARDF no.: NB078

Latitude: 62.1151

Quadrangle: NB A-2

Longitude: 141.8269

\section{Location description and accuracy:}

This occurrence is at the head of Snow Gulch, a small north tributary to Little Eldorado Creek. It is at an elevation of about 5,000 feet, 4,000 feet upstream of the mouth of Snow Gulch. The site is in the NW1/4 of section 19, T. 4 N., R. 20 E. of the Copper River Meridian. This is locality 43 of Richter and others (1975) and National Park Service locality WRST-64 (unpublished data). Cobb and Richter (1980) included this locality as an 'Unnamed occurrence'. It is located to within a few hundred feet.

\section{Commodities:}

Main: $\mathrm{Ag}, \mathrm{Cu}, \mathrm{Pb}, \mathrm{Zn}$

Other:

Ore minerals: Chalcopyrite, galena, sphalerite

Gangue minerals: Calcite(?), quartz

\section{Geologic description:}

Quartz-carbonate veins that contain sphalerite, galena, and minor chalcopyrite are present in a small exposure of Jurassic or Cretaceous argillite in this small tributary to Little Eldorado Creek (Richter and Jones, 1973; Richter and others, 1975).

\section{Alteration:}

Age of mineralization:

Jurassic or younger as Jurassic or Cretaceous sedimentary rocks host the mineralized veins.

\section{Deposit model:}

Polymetallic veins (Cox and Singer, 1986; model 22c)

Deposit model number (After Cox and Singer, 1986 or Bliss, 1992):

$22 \mathrm{c}$ 
Production Status: None

Site Status: Inactive

Workings/exploration:

Some surface prospecting has taken place along this creek.

\section{Production notes:}

\section{Reserves:}

\section{Additional comments:}

The occurrence is in the Wrangell-St. Elias National Preserve.

\section{References:}

Richter and Jones, 1973; Richter and others, 1975; Cobb and Richter, 1980.

Primary reference: Richter and others, 1975

Reporter(s): Travis L. Hudson (Applied Geology)

Last report date: $11 / 24 / 02$ 


\section{Site name(s): Bonanza Creek; Little Eldorado Creek; Skookum Creek; Coarse Money Creek; Snow Gulch}

Site type: Mine

ARDF no.: NB079

Latitude: 62.1024

Quadrangle: NB A-2

Longitude: 141.8286

\section{Location description and accuracy:}

Bonanza Creek was placer mined for about 2.3 miles of its length above the mouth of Canyon Creek. Tributaries that were placer mined on the north side of this part of Bonanza Creek, include Skookum Creek, Little Eldorado Creek, Snow Gulch, and Coarse Money Creek. These creeks are included in this record and the map site is arbitrarily plotted at the mouth of Little Eldorado Creek on Bonanza Creek. The site is in the NE1/4 of section 25, T. 4 N., R. 19 E. of the Copper River Meridian. This is locality 65 of Richter and others (1975) and National Park Service locality WRST-62 (unpublished data). Cobb and Richter (1980) included this mine under the name 'Bonanza Cr.'. It is accurately located.

\section{Commodities:}

Main: $\mathrm{Ag}, \mathrm{Au}$

Other: $\mathrm{Cu}, \mathrm{Hg}, \mathrm{Mo}, \mathrm{Pb}$

Ore minerals: Cinnabar, galena, gold, molybdenite, native copper, native silver

\section{Gangue minerals:}

\section{Geologic description:}

Bonanza Creek was placer mined for about 2.3 miles of its length above the mouth of Canyon Creek. Tributaries that were also placer mined on the north side of this part of Bonanza Creek, include Skookum Creek, Little Eldorado Creek, Snow Gulch, and Coarse Money Creek were also placer mined (Capps, 1915; Capps 1916; Moffit, 1954; Richter and Jones, 1973). The placers along Bonanza Creek were in the active stream channel and in various bench deposits including abandoned channels over 100 feet above the present stream. The placer concentrates included cinnabar, native copper, galena, molybdenite, and native silver. Much of the gold in the present stream, where gravels are 2 to 12 feet thick, was concentrated on and within the top 1 to 2.5 feet of fractured bedrock. The overburden deposits, commonly frozen, could be over 50 feet thick on the benches (Moffit, 1943). Some of the gold may have been derived from reworking of Tertiary or Quaternary gravels like those exposed on the summit of Gold Hill (Richter and Jones, 
1973). However, the mineralogical complexity of the placer concentrates suggests that this is not the only source. The tributaries and upper reaches of Bonanza Creek also rework various younger Quaternary surficial deposits that could be more locally derived. Bedrock exposed along Bonanza Creek and its tributaries is mostly Cretaceous volcanic and volcaniclastic rock, but Jurassic or Cretaceous siliciclastic rocks are present in its headwaters. Cretaceous or Tertiary dikes or small intrusive bodies are locally present. This area is about 2 miles east of Gold Hill, where the Chisana pluton intrudes Cretaceous volcanic and volcaniclastic rocks. This placer is one of several developed within or peripheral to the pluton (Richter and Jones, 1973; Richter and others, 1975).

About 50,000 ounces of gold were recovered from placers in the Chisana area (Richter and others, 1975). Most of this production was from this site and Gold Run (NB077) and about half was produced between between 1913 and 1915; some mining continued in the area up to the 1970 s.

\section{Alteration:}

Age of mineralization:

Quaternary.

\section{Deposit model:}

Placer Au (Cox and Singer, 1986; model 39a)

\section{Deposit model number (After Cox and Singer, 1986 or Bliss, 1992):} $39 \mathrm{a}$

Production Status: Yes; small

Site Status: Inactive

\section{Workings/exploration:}

Bonanza Creek was placer mined over about 2.3 miles of its length above the mouth of Canyon Creek. Tributaries that were also mined on the north side of this part of Bonanza Creek, include Skookum Creek, Little Eldorado Creek, Snow Gulch, and Coarse Money Creek were also placer mined. The bench gravels were frozen and an attempt was made to drift mine these deposits. An 85-foot deep shaft and 25-foot long drift were dug, but no paystreak was found.

\section{Production notes:}

Assuming a price of $\$ 20.00$ per ounce, about 50,000 ounces of gold were recovered from placers in the Chisana area (Richter and others, 1975). Most of this production was from the Gold Run (NB077) and Bonanza Creek (this site) drainages and about half was produced between 1913 and 1915. Some mining continued in the area up to the 1970s.

\section{Reserves:}

\section{Additional comments:}


The mine is in the Wrangell-St. Elias National Preserve.

\section{References:}

Capps, 1915; Capps, 1916; Moffit, 1943; Moffit, 1954; Richter and Jones, 1973; Richter and others, 1975; Cobb and Richter, 1980.

Primary reference: Capps, 1916

Reporter(s): Travis L. Hudson (Applied Geology)

Last report date: $11 / 24 / 02$ 


\section{Site name(s): Chathenda Creek; Johnson Creek}

Site type: Prospect

ARDF no.: NB080

Latitude: 62.0788

Quadrangle: NB A-2

Longitude: 141.9257

\section{Location description and accuracy:}

This prospect is on the north bank of Chathenda Creek about 0.9 mile upstream from the mouth of Salt Creek and 1.2 miles downstream from Bonanza. The site is in the SW1/4 of section 34, T. 4 N., R. 19 E. of the Copper River Meridian. This is locality 39 of Richter and others (1975). Cobb and Richter (1980) included this prospect under the name 'Chathenda Cr.'. It is located to within a few hundred feet.

\section{Commodities:}

Main: $\mathrm{Au}, \mathrm{Cu}$

\section{Other:}

Ore minerals: Chalcopyrite, marcasite, pyrite

Gangue minerals: Quartz

\section{Geologic description:}

This prospect consists of gold-bearing quartz-pyrite veins, some of which contain marcasite. The veins are in a zone up to 10 feet wide of mineralized, volcanic and diorite country rocks (Capps, 1916; Pilgrim, 1931, p. 66-68). The mineralized zone strikes N 65 $\mathrm{W}$ and dips $78 \mathrm{~S}$. Gold values of 0.01 and 0.10 ounce of gold per ton were reported by Pilgrim (1931). A chip sample across 5 feet of limonite-stained, fine-grained, volcanic rock contained 1.5 parts per million (ppm) silver, 1,500 ppm chromium, 500 ppm copper, and 300 ppm lead (Richter and Matson, 1970 [OFR 70-275]). The host rocks are volcanic and volcaniclastic rocks of the Cretaceous, Chisana Formation (Richter and Jones, 1973). These volcanic rocks are intruded by the mid-Cretaceous, Chisana pluton about 1,000 feet north of the prospect. The Chisana pluton varies from clinopyroxene diorite to monzonite and has been dated by K/Ar methods as 110 +/- 3.0 Ma (Richter, Lanphere, and Matson, 1975).

\section{Alteration:}

Pyrite and quartz veining and replacement(?); oxidation has produced abundant ironstaining. 


\section{Age of mineralization:}

Mid-Cretaceous? The deposit may be related to emplacement of the Chisana pluton which has a K/Ar date of 110 +/- 3.0 Ma (Richter, Lanphere, and Matson, 1975).

\section{Deposit model:}

Polymetallic veins (Cox and Singer, 1986; model 22c)

Deposit model number (After Cox and Singer, 1986 or Bliss, 1992):

$22 \mathrm{c}$

Production Status: None

Site Status: Inactive

\section{Workings/exploration:}

There are open cuts and two short adits in this area (Capps, 1916). A number of small gold-bearing quartz-pyrite lodes occur in mineralized volcanic country rock of the Cretaceous, Chisana Formation on the north side of Chathenda Creek (also see NB092 and NB093). By 1940 a large group of claims had been staked in this area but exploration, including trenches and some short adits, was unsuccessful.

\section{Production notes:}

\section{Reserves:}

\section{Additional comments:}

The prospect is in the Wrangell-St. Elias National Preserve.

\section{References:}

Capps, 1916; Pilgrim, 1931; Richter and Matson, 1970 (OFR 70-275); Richter and Jones, 1973; Richter and others, 1975; Richter, Lanphere, and Matson, 1975; Cobb and Richter, 1980.

Primary reference: Capps, 1916

Reporter(s): Travis L. Hudson (Applied Geology)

Last report date: $11 / 24 / 02$ 


\section{Site name(s): Unnamed (head of Chathenda Creek)}

Site type: Prospect

\section{ARDF no.: NB081}

Latitude: 62.1096

Quadrangle: NB A-2

Longitude: 141.6273

\section{Location description and accuracy:}

This prospect is on the south side of the uppermost headwaters of Chathenda Creek. It is at an elevation of about 6,200 feet, 1.6 miles northeast of peak 7372. The site is in the SE1/4 of section 19, T. 4 N., R. 21 E. of the Copper River Meridian. This is locality 3 of Richter and Matson (1970 [OFR 70-275]), locality 44 of Richter and others (1975), and National Park Service locality WRST-72 (unpublished data). Cobb and Richter (1980) included this prospect under the name 'Johnson Cr.'. It is located to within a few hundred feet.

\section{Commodities:}

Main: $\mathrm{Cu}$

Other: $\mathrm{Au}, \mathrm{Mo}$

Ore minerals: Chalcopyrite, molybdenite(?), pyrite

\section{Gangue minerals:}

\section{Geologic description:}

At this prospect, pyrite and chalcopyrite are disseminated in a small diorite stock and surrounding hornfels (Richter and others, 1975). The sulfide-bearing rocks are limonite stained and also locally contain abundant copper-staining along fractures (Richter and Matson, 1970 ([OFR 70-275]). Richter and others (1975) estimate that the area of hydrothermal alteration in diorite and hornfels is about 300 by 300 feet in size. The average grade of surface samples is about 0.15 percent copper and less than 0.01 percent molybdenum. A grab sample of copper-stained diorite and a grab sample representing 500 feet of pyrite-bearing argillite talus respectively contained 0.2 parts per million (ppm) and 0.04 ppm gold (Richter and Matson, 1970 [OFR 70-275]). The deposit has been estimated to contain 8 million tons with an average grade of 0.20 percent copper and very low amounts of molybdenum (Richter and others, 1975). The host diorite is inferred to be Cretaceous in age; it intrudes Jurassic or Cretaceous siliciclastic rocks (Richter and Jones, 1973).

\section{Alteration:}

Quartz-pyrite (+/- sericite?) veining and replacement; oxidation has resulted in iron- and 
copper-staining.

Age of mineralization:

Cretaceous? The age of the host diorite is inferred to be Cretaceous (Richter and Jones, 1973).

\section{Deposit model:}

Porphyry Cu-Mo (Cox and Singer, 1986; model 21a)

Deposit model number (After Cox and Singer, 1986 or Bliss, 1992):

$21 \mathrm{a}$

Production Status: None

Site Status: Inactive

Workings/exploration:

Surface prospecting has occurred since 1967.

\section{Production notes:}

\section{Reserves:}

The deposit is estimated to contain about 8 million tons of material with a grade of 0.20 percent copper and very low amounts of molybdenum (Richter and others, 1975).

\section{Additional comments:}

The prospect is in the Wrangell-St. Elias National Preserve.

\section{References:}

Richter and Matson, 1970 (OFR 70-275); Richter and Jones, 1973; Richter and others, 1975; Cobb and Richter, 1980.

Primary reference: Richter and others, 1975

Reporter(s): Travis L. Hudson (Applied Geology)

Last report date: $11 / 24 / 02$ 


\section{Site name(s): Unnamed (north side of Carl Creek)}

Site type: Prospect

ARDF no.: NB082

Latitude: 62.0451

Quadrangle: NB A-2

Longitude: 141.5805

\section{Location description and accuracy:}

This prospect is on the nose of a low, southeast-trending ridge on the east wall of the valley of Carl Creek . It is at an elevation of about 5,100 feet, about 1.1 miles southeast of peak 7064, about 1.5 miles west-northwest of peak 6820. The site is in the NW1/4 of section 16, T. 3 N., R. 21 E. of the Copper River Meridian. This is locality 5 of Richter and Matson (1970), locality 46 of Richter and others (1975), and is included in National Park Service locality 92 (unpublished data). Cobb and Richter (1980) included this prospect under the name 'Carl Cr.'. It is located to within a few hundred feet.

\section{Commodities:}

Main: $\mathrm{Cu}$

Other: $\mathrm{Ag}, \mathrm{Au}, \mathrm{Mo}$

Ore minerals: Chalcopyrite, molybdenite(?), pyrite

Gangue minerals: Quartz, sericite

\section{Geologic description:}

Pyrite and chalcopyrite occur in quartz veinlets and as disseminations in granodiorite and quartz monzonite of the Cretaceous, Klein Creek pluton (Richter and Matson, 1970 [OFR 70-275]; Richter and others, 1975; Richter and Jones, 1973; Richter, Lanphere, and Matson, 1975). The mineralization is in a 300- by 600 -foot hydrothermally altered zone characterized by veins of quartz and sericite. Surface samples average about 0.01 percent copper and less than 0.01 percent molybdenum. A grab sample of limonite-stained granodiorite contained 0.2 parts per million (ppm ) gold and 700 ppm copper (Richter and Matson, 1970 [OFR 70-275]). The deposit is estimated to contain about 8 million tons of material with a grade of 0.20 percent copper and very low amounts of molybdenum (Richter and others, 1975). The Klein Creek pluton has a K/Ar date of $111+/-3.6 \mathrm{Ma}$ (Richter, Lanphere, and Matson, 1975). This pluton intrudes volcanic rocks of the Cretaceous, Chisana Formation in the area of Carl Creek (Richter and Jones, 1973).

\section{Alteration:}

Quartz-sericite-pyrite veining and replacement(?); oxidation has produced iron- and 
copper-staining.

Age of mineralization:

Related to Cretaceous pluton; the Klein Creek pluton has a K/Ar date of $111+/-3.6 \mathrm{Ma}$ (Richter, Lanphere, and Matson, 1975).

Deposit model:

Porphyry Cu-Mo (Cox and Singer, 1986; model 21a)

Deposit model number (After Cox and Singer, 1986 or Bliss, 1992):

$21 \mathrm{a}$

Production Status: None

Site Status: Inactive

Workings/exploration:

Surface prospecting has occurred since 1967.

Production notes:

Reserves:

The deposit is estimated to contain about 8 million tons of material with a grade of 0.20 percent copper and very low amounts of molybdenum (Richter and others, 1975).

\section{Additional comments:}

The prospect is in the Wrangell-St. Elias National Preserve.

\section{References:}

Richter and Matson, 1970 (OFR 70-275); Richter and Jones, 1973; Richter and others, 1975; Richter, Lanphere, and Matson, 1975; Cobb and Richter, 1980.

Primary reference: Richter and others, 1975

Reporter(s): Travis L. Hudson (Applied Geology)

Last report date: $11 / 24 / 02$ 


\section{Site name(s): Dry Gulch}

Site type: Prospect

ARDF no.: NB083

Latitude: 62.1180

Quadrangle: NB A-2

Longitude: 141.9980

\section{Location description and accuracy:}

This prospect is on lower Dry Gulch at an elevation of approximately 3,800 feet. The prospect is near the center of the south boundary of section 18, T. 4 N., R. 19 E. of the Copper River Meridian. This is National Park Service locality WRST-54 (unpublished data) and the coordinates for this prospect were provided by the National Park Service.

\section{Commodities:}

Main: $\mathrm{Au}$

\section{Other:}

Ore minerals: Gold

\section{Gangue minerals:}

\section{Geologic description:}

An unpublished National Park Service map and accompanying database identify this as a placer gold prospect that was active as early as 1914. Most of the bedrock in Dry Gulch varies from clinopyroxene diorite to monzonite of the mid-Cretaceous, Chisana pluton (Richter, 1976). The site is near the northwest contact of this pluton with Cretaceous volcanic and volcaniclastic rocks, which in turn overlie Jurassic or Cretaceous siliciclastic rocks to the north (Richter and Jones, 1973; Richter, 1976).

\section{Alteration:}

Age of mineralization:

Quaternary.

\section{Deposit model:}

Placer Au (Cox and Singer, 1986; model 39a)

Deposit model number (After Cox and Singer, 1986 or Bliss, 1992):

$39 a$ 
Production Status: Undetermined.

Site Status: Inactive

Workings/exploration:

Some placer prospecting probably took place along this creek.

\section{Production notes:}

\section{Reserves:}

\section{Additional comments:}

The prospect is in the Wrangell-St. Elias National Preserve.

\section{References:}

Richter and Jones, 1973; Richter, 1976.

Primary reference: This record

Reporter(s): Travis L. Hudson (Applied Geology)

Last report date: $11 / 24 / 02$ 


\section{Site name(s): Ole; Jay 1-3; Easy Money}

Site type: Mine

ARDF no.: NB084

Latitude: 62.1255

Quadrangle: NB A-2

Longitude: 141.9593

\section{Location description and accuracy:}

This placer mine is on Chavolda Creek at the mouth of Big Eldorado Creek. The mine is near the center of the west side of section 16, T. 4 N., R. 19 E. of the Copper River Meridian. This is locality 62 of Richter and others (1975) and National Park Service localities WRST-56, WRST-57, and WRST-58 (unpublished data). The location is accurate to within about 1,000 feet.

\section{Commodities:}

Main: $\mathrm{Au}$

\section{Other:}

Ore minerals: Gold

\section{Gangue minerals:}

\section{Geologic description:}

A small amount of coarse, smooth placer gold was mined from this area (Richter and others, 1975). The active drainage of Chavolda Creek reworks Quaternary colluvial materials derived from the flanks of the surrounding uplands, including Gold Hill to the southeast (Richter and Jones, 1973). At Gold Hill, the Chisana pluton intrudes Cretaceous volcanic and volcaniclastic rocks; this placer is one of several developed within or peripheral to the pluton (Richter and Jones, 1973; Richter and others, 1975). The Chisana pluton varies from clinopyroxene diorite to monzonite and is mid-Cretaceous in age; a K/Ar date for this pluton is $110+/-3.2 \mathrm{Ma}$ (Richter, Lanphere, and Matson, 1975).

\section{Alteration:}

Age of mineralization:

Quaternary.

\section{Deposit model:}

Placer Au (Cox and Singer, 1986; model 39a) 
Deposit model number (After Cox and Singer, 1986 or Bliss, 1992):

$39 \mathrm{a}$

Production Status: Yes; small

Site Status: Inactive

Workings/exploration:

Some surface placer workings are present at this location (Richter and others, 1975).

Production notes:

Assuming a price of $\$ 20.00$ per ounce, about 50,000 ounces of gold were recovered from placers in the Chisana area (Richter and others, 1975). Most of this production was from the Gold Run (NB077) and Bonanza Creek (NB079) drainages and about half was produced between 1913 and 1915. Some mining continued in the area up to the 1970s.

\section{Reserves:}

\section{Additional comments:}

The mine is in the Wrangell-St. Elias National Preserve.

\section{References:}

Richter and Jones, 1973; Richter and others, 1975; Richter, Lanphere, and Matson, 1975.

Primary reference: Richter and others, 1975

Reporter(s): Travis L. Hudson (Applied Geology)

Last report date: $11 / 24 / 02$ 


\section{Site name(s): Chavolda Creek}

Site type: Mine

ARDF no.: NB085

Latitude: 62.1306

Quadrangle: NB A-2

Longitude: 141.9268

\section{Location description and accuracy:}

This placer mine is on Chavolda Creek just downstream from the mouth of Glacier Creek. The site is in the NE1/4 of section 16, T. 4 N., R. 19 E. of the Copper River Meridian. It is National Park Service locality WRST-55 (unpublished data). Richter and others (1975) show placer mine workings at this locality.

\section{Commodities:}

Main: $\mathrm{Au}$

\section{Other:}

Ore minerals: Gold

Gangue minerals:

\section{Geologic description:}

A small amount of coarse, smooth placer gold was mined from Chavolda Creek just downstream from the mouth of Glacier Creek. The headwaters of Glacier Creek include Gold Run Creek, where a significant part of the estimated 50,000 ounces of gold produced from placers the Chisana area were recovered (Richter and others, 1975). The active drainage of Chavolda Creek reworks Quaternary colluvial materials derived from the flanks of the surrounding uplands including Gold Hill to the southeast (Richter and Jones, 1973). At Gold Hill, the Chisana pluton intrudes Cretaceous volcanic and volcaniclastic rocks; this placer is one of several developed within or peripheral to the pluton (Richter and Jones, 1973; Richter and others, 1975). The Chisana pluton varies from clinopyroxene diorite to monzonite and is mid-Cretaceous in age; a K/Ar date for this pluton is 110 +/- 3.2 Ma (Richter, Lanphere, and Matson, 1975).

\section{Alteration:}

Age of mineralization:

Quaternary.

\section{Deposit model:}


Placer Au (Cox and Singer, 1986; model 39a)

Deposit model number (After Cox and Singer, 1986 or Bliss, 1992):

$39 \mathrm{a}$

Production Status: Yes; small

Site Status: Inactive

Workings/exploration:

Some surface placer workings are present at this location (Richter and others, 1975).

Production notes:

Assuming a price of $\$ 20.00$ per ounce, about 50,000 ounces of gold were recovered from placers in the Chisana area (Richter and others, 1975). Most of this production was from the Gold Run (NB077) and Bonanza Creek (NB079) drainages and about half was produced between 1913 and 1915. Some mining continued in the area up to the 1970s.

\section{Reserves:}

Additional comments:

The mine is in the Wrangell-St. Elias National Preserve.

\section{References:}

Richter and Jones, 1973; Richter and others, 1975; Richter, Lanphere, and Matson, 1975.

Primary reference: Richter and others, 1975

Reporter(s): Travis L. Hudson (Applied Geology)

Last report date: $11 / 24 / 02$ 


\section{Site name(s): Chickenlicken}

Site type: Prospect

ARDF no.: NB086

Latitude: 62.1202

Quadrangle: NB A-2

Longitude: 141.8419

\section{Location description and accuracy:}

This prospect is in the headwaters of Pensive Pup, a small headwater tributary to Little Eldorado Creek. It is at an elevation of about 5,500 feet, about 1 mile northeast of the small pond at Caribou Pass. The prospect is near the southeast corner of the NE1/4 of section 13, T. 4 N., R. 19 E. of the Copper River Meridian. This is National Park Service locality WRST-63 (unpublished data) and the coordinates for this prospect were provided by the National Park Service.

\section{Commodities:}

Main: $\mathrm{Au}$

\section{Other:}

Ore minerals: Gold

\section{Gangue minerals:}

\section{Geologic description:}

An unpublished National Park Service map and accompanying database identify this as a placer gold prospect where one claim was active from 1916 to as recently as 1963. It is in the headwaters of Pensive Pup, a small headwater tributary to Little Eldorado Creek. Pensive Pup reworks Quaternary colluvial and glacial deposits downslope from exposures of Jurassic marine siliciclastic rocks (Richter and Jones, 1973). Some of the glacial deposits may have been derived from the Gold Hill area to the south, where the midCretaceous, Chisana pluton intrudes Cretaceous volcanic and volcaniclastic rocks (Richter and Jones, 1973). This placer is one of several developed within or peripheral to the Chisana pluton (Richter and Jones, 1973; Richter and others, 1975).

\section{Alteration:}

Age of mineralization:

Quaternary.

\section{Deposit model:}


Placer Au (Cox and Singer, 1986; model 39a)

Deposit model number (After Cox and Singer, 1986 or Bliss, 1992): $39 \mathrm{a}$

Production Status: Undetermined.

Site Status: Inactive

Workings/exploration:

Some placer prospecting occurred here.

Production notes:

Reserves:

Additional comments:

The prospect is in the Wrangell-St. Elias National Preserve.

\section{References:}

Richter and Jones, 1973; Richter and others, 1975.

Primary reference: This record

Reporter(s): Travis L. Hudson (Applied Geology)

Last report date: $11 / 24 / 02$ 


\section{Site name(s): Chathenda Creek}

Site type: Prospect

ARDF no.: NB087

Latitude: 62.0702

Quadrangle: NB A-2

Longitude: 141.9360

\section{Location description and accuracy:}

This placer prospect is on Chathenda Creek near the mouth of Salt Creek in the NE1/4 of section 4, T. 3 N., R. 19 E. of the Copper River Meridian. This is National Park Service locality WRST-68 (unpublished data) and the coordinates of this prospect were provided by the National Park Service.

\section{Commodities:}

Main: $\mathrm{Au}$

Other:

Ore minerals: Gold

Gangue minerals:

\section{Geologic description:}

An unpublished National Park Service map and accompanying database identify this as a placer gold prospect that was active as early as 1914. Bedrock in Chathenda Creek is Cretaceous volcanic and volcaniclastic rocks peripheral to and south of the midCretaceous, Chisana pluton (Richter and Jones, 1973). This prospect is one of several placer prospects and mines developed within or peripheral to the pluton (Richter and Jones, 1973; Richter and others, 1975).

\section{Alteration:}

Age of mineralization:

Quaternary.

\section{Deposit model:}

Placer Au (Cox and Singer, 1986; model 39a)

Deposit model number (After Cox and Singer, 1986 or Bliss, 1992):

$39 \mathrm{a}$ 
Production Status: Undetermined.

Site Status: Inactive

Workings/exploration:

Some placer prospecting occurred here.

\section{Production notes:}

Reserves:

Additional comments:

References:

Richter and Jones, 1973; Richter and others, 1975.

Primary reference: This record

Reporter(s): Travis L. Hudson (Applied Geology)

Last report date: $11 / 24 / 02$ 


\section{Site name(s): Unnamed (on Chathenda Creek)}

Site type: Prospect

ARDF no.: NB088

Latitude: 62.0605

Quadrangle: NB A-2

Longitude: 141.9742

\section{Location description and accuracy:}

This prospect is on Chathenda Creek about 2,000 feet downstream from the mouth of Rhyolite Creek. The prospect is at about the center of the north side of section 8, T. 3 N., R. 19 E. of the Copper River Meridian. This locality was identified as locality WRST-69 on an unpublished National Park Service map but the accompanying database contained information for Gold Run Creek (NB077) instead of Chathenda Creek. The prospect is assumed to be a valid locality, although data other than location are not available.

\section{Commodities:}

Main: Au?

\section{Other:}

Ore minerals: Gold?

\section{Gangue minerals:}

\section{Geologic description:}

This prospect was identified on an unpublished National Park Service mineral occurrence map but the accompanying database contained information for Gold Run Creek (NB077) instead of Chathenda Creek. It is assumed to be a valid locality, probably a placer gold prospect, although data other than location are not available. Bedrock in Chathenda Creek is Cretaceous volcanic and volcaniclastic rocks peripheral and south of the mid-Cretaceous, Chisana pluton (Richter and Jones, 1973).

\section{Alteration:}

Age of mineralization:

Quaternary?

\section{Deposit model:}

Placer Au? (Cox and Singer, 1986; model 39a)

Deposit model number (After Cox and Singer, 1986 or Bliss, 1992): 
$39 a ?$

Production Status: Undetermined.

Site Status: Inactive

Workings/exploration:

Some placer gold prospecting may have occurred here.

Production notes:

Reserves:

Additional comments:

The prospect is in the Wrangell-St. Elias National Preserve.

\section{References:}

Richter and Jones, 1973.

Primary reference: This record

Reporter(s): Travis L. Hudson (Applied Geology)

Last report date: $11 / 24 / 02$ 


\section{Site name(s): Upper Chathenda Creek}

Site type: Prospect

ARDF no.: NB089

Latitude: 62.1101

Quadrangle: NB A-2

Longitude: 141.6560

\section{Location description and accuracy:}

This prospect is on the south side of the valley of upper Chathenda Creek at an elevation of about 5,300 feet. It is 1.1 mile north-northeast of peak 7372, about 0.3 mile east of the center of section 24, T. 4 N., R. 20 E. of the Copper River Meridian. This is National Park Service locality WRST-71 (unpublished data) and the corodinates of this prospect were provided by the National Park Service.

\section{Commodities:}

Main: $\mathrm{Cu}$

Other:

Ore minerals:

Gangue minerals:

\section{Geologic description:}

An unpublished National Park Service map and accompanying database identify this locality as a copper prospect where 30 lode claims were active in 1971. Bedrock in this area is Jurassic or Cretaceous siliciclastic rocks that are locally intruded by Cretaceous and/or Tertiary dikes and small stocks (Richter and Jones, 1973).

\section{Alteration:}

Age of mineralization:

Cretaceous or Tertiary? The prospect is in an area where Cretaceous or Tertiary intrusive rocks intrude Jurassic or Cretaceous sedimentary rocks (Richter and Jones, 1973).

\section{Deposit model:}

Deposit model number (After Cox and Singer, 1986 or Bliss, 1992):

Production Status: None 
Site Status: Inactive

Workings/exploration:

Thirty lode claims were active in 1971 and at least some surface prospecting has taken place.

Production notes:

Reserves:

Additional comments:

The prospect is in the Wrangell-St. Elias National Preserve.

\section{References:}

Richter and Jones, 1973.

Primary reference: This record

Reporter(s): Travis L. Hudson (Applied Geology)

Last report date: $11 / 24 / 02$ 
Site name(s): Mary Ellen

Site type: Prospect

ARDF no.: NB090

Latitude: 62.0882

Quadrangle: NB A-2

Longitude: 141.5155

\section{Location description and accuracy:}

This prospect is in the headwater cirque to an unnamed south tributary to Klein Creek. It is at an elevation of about 6,900 feet, about 1,500 feet southeast of peak 7730 . The site is in the SW1/4 of section 26, T. 4 N., R. 21 E. of the Copper River Meridian. This is National Park Service locality WRST-73 (unpublished data) and the coordinates for this record were provided by the National Park Service.

\section{Commodities:}

Main: $\mathrm{Ag}, \mathrm{Au}, \mathrm{Cu}, \mathrm{Pb}$

\section{Other:}

\section{Ore minerals:}

\section{Gangue minerals:}

\section{Geologic description:}

An unpublished National Park Service map and accompanying database identify this locality as a copper, silver, gold, and lead prospect where 6 lode claims were active from 1972 to 1981. The prospect is near the northwest contact of the Klein Creek pluton with Jurassic or Cretaceous siliciclastic rocks (Richter and Jones, 1973). The Klein Creek pluton varies from gabbro to granodiorite and has concordant biotite/hornblende K/Ar ages of 111 +/- 3.6 Ma (Richter, Lanphere, and Matson, 1975).

\section{Alteration:}

\section{Age of mineralization:}

Mid-Cretaceous? The deposit is probably related to emplacement of the Klein Creek pluton which has concordant biotite/hornblende K/Ar ages of 111 +/- 3.6 Ma (Richter, Lanphere, and Matson, 1975).

\section{Deposit model:}

Deposit model number (After Cox and Singer, 1986 or Bliss, 1992): 
Production Status: None

Site Status: Inactive

Workings/exploration:

Six lode claims were active in this area from 1972 to 1981 and at least some surface prospecting has taken place.

Production notes:

Reserves:

Additional comments:

The prospect is in the Wrangell-St. Elias National Preserve.

References:

Richter and Jones, 1973; Richter, Lanphere, and Matson, 1975.

Primary reference: This record

Reporter(s): Travis L. Hudson (Applied Geology)

Last report date: $11 / 24 / 02$ 


\section{Site name(s): Unnamed (north of Carl Creek)}

Site type: Prospect

ARDF no.: NB091

Latitude: 62.0520

Quadrangle: NB A-2

Longitude: 141.5937

\section{Location description and accuracy:}

This prospect is on the side of a ridge that makes up the north wall of Carl Creek. It is at an elevation of about 6,000 feet, about 2,500 feet south of peak 7064. The prospect is about 0.3 mile east-southwest of the center of section 8, T. 3 N., R. 21 E. of the Copper River Meridian. This is locality 4 of Richter and Matson (1970 [OFR 70-275]), locality 45 of Richter and others (1975), and is included in National Park Service locality 92 (unpublished data). Cobb and Richter (1980) included this prospect under the name 'Carl Cr.'. It is located to within a few hundred feet.

\section{Commodities:}

Main: $\mathrm{Cu}$

Other: Ag, $\mathrm{Au}, \mathrm{Mo}$

Ore minerals: Chalcopyrite, molybdenite?, pyrite

Gangue minerals: Quartz, sericite

\section{Geologic description:}

This porphyry copper-molybdenum deposit is similar to the one at NB082, which is located 4,000 feet to the southeast. Pyrite and chalcopyrite occur in quartz veinlets and as disseminations in granodiorite and quartz monzonite of the Cretaceous, Klein Creek pluton (Richter and Matson, 1970 [OFR 70-275]; Richter and others, 1975; Richter and Jones, 1973; Richter, Lanphere, and Matson, 1975). The mineralization is in a 300- by 600 -foot hydrothermally altered zone characterized by veins of quartz and sericite. Surface samples average about 0.01 percent copper and less than 0.01 percent molybdenum. A grab sample of limonite-stained granodiorite contained 1.5 parts per million (ppm) silver, 15,000 ppm copper, 15 ppm molybdenum, and 300 ppm zinc (Richter and Matson, 1970 [OFR 70-275]). The deposit is estimated to contain about 8 million tons of material that average 0.20 percent copper and very low amounts of molybdenum (Richter and others, 1975). The Klein Creek pluton has a K/Ar date of 111 +/- 3.6 Ma (Richter, Lanphere, and Matson, 1975). In the area of Carl Creek, the porphyry intrudes volcanic rocks of the Cretaceous, Chisana Formation (Richter and Jones, 1973). 
Alteration:

Quartz-sericite-pyrite veining and replacement(?). Oxidation has produced iron- and copper-staining.

Age of mineralization:

Cretaceous; the Klein Creek pluton has a K/Ar date of 111 +/- 3.6 Ma (Richter, Lanphere, and Matson, 1975).

\section{Deposit model:}

Porphyry Cu-Mo (Cox and Singer, 1986; model 21a)

Deposit model number (After Cox and Singer, 1986 or Bliss, 1992):

$21 \mathrm{a}$

Production Status: None

Site Status: Inactive

\section{Workings/exploration:}

Surface prospecting has occurred since 1967.

\section{Production notes:}

Reserves:

\section{Additional comments:}

The prospect is in the Wrangell-St. Elias National Preserve.

\section{References:}

Richter and Matson, 1970 (OFR 70-275); Richter and Jones, 1973; Richter and others, 1975; Richter, Lanphere, and Matson, 1975; Cobb and Richter, 1980.

Primary reference: Richter and others, 1975

Reporter(s): Travis L. Hudson (Applied Geology)

Last report date: $11 / 24 / 02$ 


\section{Site name(s): Unnamed (north of lower Chathenda Creek)}

Site type: Prospect

ARDF no.: NB092

Latitude: 62.0848

Quadrangle: NB A-2

Longitude: 141.8836

\section{Location description and accuracy:}

This prospect is at an elevation of about 4,900 feet on the north valley wall of lower Chathenda Creek. It is 3,000 feet northwest of Bonanza and 3,500 feet southeast of the summit of hill 5940. The site is in the NW1/4 of section 36, T. 4 N., R. 19 E., of the Copper River Meridian. This is locality 41 of Richter and others (1975) and may be included in National Park Service locality WRST-60 or WRST-61 (unpublished data). Cobb and Richter (1980) included this prospect under the name 'Cathenda Cr.'. It is located to within a few hundred feet.

\section{Commodities:}

Main: $\mathrm{Au}$

\section{Other:}

Ore minerals: Gold, pyrite

Gangue minerals: Quartz

\section{Geologic description:}

At this prospect, gold-bearing quartz-pyrite veins locally cut iron-oxide-stained altered zones in volcanic breccia of the Cretaceous, Chisana Formation (Richter and Matson, 1970 [OFR 70-275]; Richter and Jones, 1973; Richter and others, 1975). The volcanic rocks are intruded by the mid-Cretaceous, Chisana pluton about 3,000 feet northwest of the prospect. The Chisana pluton varies from clinopyroxene diorite to monzonite and has a K/Ar date of 110 +/- 3.0 Ma (Richter, Lanphere, and Matson, 1975).

\section{Alteration:}

Pyrite and quartz veining and replacement(?). Oxidation has produced abundant ironstaining.

\section{Age of mineralization:}

Mid-Cretaceous? The deposit may be related to emplacement of the Chisana pluton which has a K/Ar date of 110 +/- 3.0 Ma (Richter, Lanphere, and Matson, 1975). 


\section{Deposit model:}

Polymetallic veins (Cox and Singer, 1986; model 22c)

Deposit model number (After Cox and Singer, 1986 or Bliss, 1992):

$22 \mathrm{c}$

Production Status: None

Site Status: Inactive

\section{Workings/exploration:}

A number of small gold-bearing quartz-pyrite lodes occur in mineralized volcanic country rock of the Cretaceous, Chisana Formation on the north side of Chathenda Creek (also see NB080 and NB093). By 1940 a large group of claims had been staked in this area but exploration, including trenches and some short adits, was unsuccessful.

\section{Production notes:}

\section{Reserves:}

\section{Additional comments:}

The prospect is in the Wrangell-St. Elias National Preserve.

\section{References:}

Richter and Matson, 1970 (OFR 70-275); Richter and Jones, 1973; Richter and others, 1975; Richter, Lanphere, and Matson, 1975; Cobb and Richter, 1980.

Primary reference: Richter and Jones, 1973

Reporter(s): Travis L. Hudson (Applied Geology)

Last report date: $11 / 24 / 02$ 


\section{Site name(s): Unnamed (north of lower Chathenda Creek)}

Site type: Prospect

ARDF no.: NB093

Latitude: 62.0819

Quadrangle: NB A-2

Longitude: 141.8933

\section{Location description and accuracy:}

This prospect is at an elevation of about 4,700 feet on the north valley wall of lower Chathenda Creek. It is 3,000 feet northwest of Bonanza and 3,500 feet southeast of the summit of hill 5940. The site is in the NW1/4 of section 35, T. 4 N., R. 19 E., of the Copper River Meridian. This is locality 40 of Richter and others (1975) and may be included in National Park Service locality WRST-60 or WRST-61 (unpublished data). Cobb and Richter (1980) included this prospect under the name 'Chathenda Cr.'. It is located to within a few hundred feet.

\section{Commodities:}

Main: $\mathrm{Au}$

\section{Other:}

Ore minerals: Gold, pyrite

\section{Gangue minerals:}

\section{Geologic description:}

At this prospect, gold-bearing quartz-pyrite veins locally cut iron-oxide-stained altered zones in volcanic breccia of the Cretaceous, Chisana Formation (Richter and Matson, 1970 [OFR 70-275]; Richter and Jones, 1973; Richter and others, 1975). The volcanic rocks are intruded by the mid-Cretaceous, Chisana pluton about 4,000 feet northwest of the prospect. The Chisana pluton varies from clinopyroxene diorite to monzonite and has a K/Ar date of 110 +/- 3.0 Ma (Richter, Lanphere, and Matson, 1975).

\section{Alteration:}

Pyrite and quartz veining and replacement(?). Oxidation has produced abundant ironstaining.

\section{Age of mineralization:}

Mid-Cretaceous? The deposit may be related to emplacement of the Chisana pluton which has a K/Ar date of 110 +/- 3.0 Ma (Richter, Lanphere, and Matson, 1975). 


\section{Deposit model:}

Polymetallic veins (Cox and Singer, 1986; model 22c)

Deposit model number (After Cox and Singer, 1986 or Bliss, 1992):

$22 \mathrm{c}$

Production Status: None

Site Status: Inactive

\section{Workings/exploration:}

A number of small gold-bearing quartz-pyrite lodes occur in mineralized volcanic country rock of the Cretaceous, Chisana Formation on the north side of Chathenda Creek (also see NB080 and NB092). By 1940 a large group of claims had been staked in this area but exploration, including trenches and some short adits, was unsuccessful.

\section{Production notes:}

\section{Reserves:}

\section{Additional comments:}

The prospect is in the Wrangell-St. Elias National Preserve.

\section{References:}

Richter and Matson, 1970 (OFR 70-275); Richter and Jones, 1973; Richter and others, 1975; Richter, Lanphere, and Matson, 1975; Cobb and Richter, 1980.

Primary reference: Richter and Jones, 1973

Reporter(s): Travis L. Hudson (Applied Geology)

Last report date: $11 / 24 / 02$ 


\section{Site name(s): Sulzer; Cosmopolitan Group; O'Hara Property}

Site type: Prospect

ARDF no.: NB094

Latitude: 62.1966

Quadrangle: NB A-1

Longitude: 141.4586

\section{Location description and accuracy:}

This prospect is on the ridge south of lower East Fork, Snag Creek. It is at an elevation of about 5,400 feet , 1,500 feet southeast of peak 5664. The prospect is 0.2 mile east of the center of section 23, T. 5 N., R. 21 E. of the Copper River Meridian. This is locality 1 of Richter and others (1973) and locality 47 of Richter and others (1975]). Cobb and Richter (1980) included this prospect under the name 'Sulzer'. It is located to within a few hundred feet.

\section{Commodities:}

Main: $\mathrm{Cu}$

\section{Other:}

Ore minerals: Bornite, malachite, native copper

\section{Gangue minerals:}

\section{Geologic description:}

This prospect consists of malachite and bornite in fractures and filling amygdules in Triassic, Nikolai Greenstone (Matson and Richter, 1971 [OFR 71-202]; Richter and others, 1975). An adit was driven at least 87 feet along a northwest- trending fracture zone in a flow breccia and an overlying amygdaloidal basalt (Pilgrim, 1931; Moffit, 1943; 1954). Copper mineralization is locally common in Nikolai Greenstone and is thought to have accompanied regional deformation and low-grade metamorphism in the Late Jurassic to Early Cretaceous (MacKevett and others, 1997).

\section{Alteration:}

Low-grade metamorphic assemblages including quartz, calcite, epidote, zeolites; some native copper replaces basalt or fills amygdules (Richter and others, 1973).

\section{Age of mineralization:}

Cretaceous? Copper mineralization is locally common in Nikolai Greenstone and is thought to have accompanied regional deformation and low-grade metamorphism in the Late Jurassic to Early Cretaceous (MacKevett and others, 1997). 


\section{Deposit model:}

Basaltic copper (Cox and Singer, 1986; model 23)

Deposit model number (After Cox and Singer, 1986 or Bliss, 1992):

23

Production Status: Undetermined.

Site Status: Inactive

\section{Workings/exploration:}

This prospect was explored by some open cuts and two adits. One adit was at least 87 feet long (Moffit, 1943).

\section{Production notes:}

\section{Reserves:}

Additional comments:

The prospect is in the Wrangell-St. Elias National Preserve.

\section{References:}

Pilgrim, 1931; Moffit, 1943; Moffit, 1954; Matson and Richter, 1971 (OFR 71-202); Richter and others, 1973; Richter and others, 1975; Cobb and Richter, 1980; MacKevett and others, 1997.

Primary reference: Moffit, 1954

Reporter(s): Travis L. Hudson (Applied Geology)

Last report date: $11 / 24 / 02$ 


\section{Site name(s): Reynolds; Butte Creek Copper Group}

Site type: Prospect

ARDF no.: NB095

Latitude: 62.1828

Quadrangle: NB A-1

Longitude: 141.4276

\section{Location description and accuracy:}

This prospect is 2,000 feet west of upper Reynolds Creek, a south tributary to the East Fork, Snag Creek. It is at an elevation of about 5,300 feet, 5,000 feet northeast of peak 6827. The site is 0.2 mile east of the center of section 25, T. 5 N., R. 21 E. of the Copper River Meridian. This is locality 2 of Richter and others (1973) and locality 48 of Richter and others (1975). Cobb and Richter (1980) included this prospect under the name 'Reynolds'. It is located to within a few hundred feet.

\section{Commodities:}

Main: $\mathrm{Cu}$

\section{Other:}

Ore minerals: Bornite, chalcocite, malachite

Gangue minerals: Calcite, specularite

\section{Geologic description:}

Small veins of bornite, chalcocite, specularite, malachite, and calcite cut amygdaloidal basalt of the Triassic, Nikolai Greenstone (Moffit, 1943). The deposits were explored by several open cuts. A chip sample across 5 feet of iron-stained greenstone contained 50 parts per million (ppm) boron, 150 ppm copper, 70 ppm nickel, and 200 ppm vanadium (Matson and Richter, 1971 [OFR 71-202]). Copper mineralization is locally common in Nikolai Greenstone and is thought to have accompanied regional deformation and lowgrade metamorphism in the Late Jurassic to Early Cretaceous (MacKevett and others, 1997).

\section{Alteration:}

Low-grade metamorphic assemblages including quartz, calcite, epidote, zeolites, and some native copper replace basalt or fill amygdules (Richter and others, 1973).

\section{Age of mineralization:}

Cretaceous? Copper mineralization is locally common in Nikolai Greenstone and is thought to have accompanied regional deformation and low-grade metamorphism in the 
Late Jurassic to Early Cretaceous (MacKevett and others, 1997).

Deposit model:

Basaltic copper (Cox and Singer, 1986; model 23)

Deposit model number (After Cox and Singer, 1986 or Bliss, 1992):

23

Production Status: None

Site Status: Inactive

Workings/exploration:

The deposits were explored by several open cuts.

Production notes:

Reserves:

Additional comments:

The prospect is in the Wrangell-St. Elias National Preserve.

\section{References:}

Moffit, 1943; Matson and Richter, 1971 (OFR 71-202); Richter and others, 1973; Richter and others, 1975; Cobb and Richter, 1980; MacKevett and others, 1997.

Primary reference: Moffit, 1943

Reporter(s): Travis L. Hudson (Applied Geology)

Last report date: $11 / 24 / 02$ 


\section{Site name(s): Unnamed (north of upper Baultoff Creek)}

Site type: Occurrence

ARDF no.: NB096

Latitude: 62.1459

Quadrangle: NB A-1

Longitude: 141.3042

\section{Location description and accuracy:}

This occurrence is on the ridge between the headwaters of the East Fork, Snag Creek and Baultoff Creek. It is at a elevation of about 6,800 feet, 500 feet southeast of peak 7316. The occurrence is about 0.6 mile southwest of the center of section 1, T. 4 N., R. 22 E. of the Copper River Meridian. This is locality 3 of Richter and others (1973), locality 49 of Richter and others (1975), and National Park Service locality WRST-79 (unpublished data). Cobb and Richter (1980) included this locality as an 'Unnamed occurrence'. It is located to within a few hundred feet.

\section{Commodities:}

Main: $\mathrm{Cu}$

Other:

Ore minerals: Chalcopyrite, pyrite

Gangue minerals: Quartz

\section{Geologic description:}

This occurrence is a massive quartz vein that contains minor pyrite and chalcopyrite and cuts Permian marine volcaniclastic rocks (Richter and others, 1973; 1975).

\section{Alteration:}

Silicification.

Age of mineralization:

Permian or younger; the host rocks cut by the mineralized quartz vein are Permian.

\section{Deposit model:}

Copper-bearing vein

Deposit model number (After Cox and Singer, 1986 or Bliss, 1992):

Production Status: None 
Site Status: Inactive

Workings/exploration:

Production notes:

\section{Reserves:}

Additional comments:

The occurrence is in the Wrangell-St. Elias National Preserve.

\section{References:}

Richter and others, 1973; Richter and others, 1975; Cobb and Richter, 1980.

Primary reference: Richter and others, 1975

Reporter(s): Travis L. Hudson (Applied Geology)

Last report date: $11 / 24 / 02$ 


\section{Site name(s): Unnamed (south of upper Gravel Creek)}

Site type: Prospect

ARDF no.: NB097

Latitude: 62.0786

Quadrangle: NB A-1

Longitude: 141.2527

\section{Location description and accuracy:}

This prospect is about 1,500 feet south of upper Gravel Creek and 2,000 feet northnorthwest of peak 7510. The prospect is about 0.5 mile east-southeast of the center of section 31, T. 4 N., R. 23 E. of the Copper River Meridian. This is locality 5 of Richter and others (1973), locality 50 of Richter and others (1975), and National Park Service locality WRST-88 (unpublished data). It is located to within a few hundred feet.

\section{Commodities:}

Main: $\mathrm{Cu}$

Other: Mo

Ore minerals: Chalcopyrite, molybdenite(?), pyrite

\section{Gangue minerals:}

\section{Geologic description:}

Disseminated pyrite and minor chalcopyrite occur in diorite near its contact with Jurassic or Cretaceous siliciclastic rocks (Richter and others, 1973). The deposit is marked by a hydrothermal alteration zone 300 by 1,000 feet in size. Surface samples average less than 0.10 percent copper and less than 0.01 percent molybdenum (Matson and Richter, 1971 [OFR 71-202]; Richter and others, 1975). The deposit is estimated to contain 12 million tons of material with an average grade of 0.20 percent copper and very low molybdenum (Richter and others, 1975). The diorite host rock is considered part of the Klein Creek pluton which has a K/Ar date of 111 +/- 3.6 Ma (Richter, Lanphere, and others, 1975).

\section{Alteration:}

A hydrothermal alteration zone is developed over an area of about 300 by 1,000 feet. Oxidation has resulted in iron-staining of this area.

\section{Age of mineralization:}

Mid-Cretaceous; the diorite host rock is part of the Klein Creek pluton which has a K/ Ar date of 111 +/- 3.6 Ma (Richter, Lanphere, and Matson, 1975). 


\section{Deposit model:}

Porphyry Cu-Mo (Cox and Singer, 1986; model 21a)

Deposit model number (After Cox and Singer, 1986 or Bliss, 1992):

$21 \mathrm{a}$

Production Status: None

Site Status: Inactive

\section{Workings/exploration:}

There has been some surface exploration.

\section{Production notes:}

\section{Reserves:}

The deposit is estimated to contain 12 million tons of material with an average grade of 0.20 percent copper and very low amounts of molybdenum (Richter and others, 1975).

\section{Additional comments:}

The prospect is in the Wrangell-St. Elias National Preserve.

\section{References:}

Matson and Richter, 1971 (OFR 71-202); Richter and others, 1973; Richter and others, 1975.

Primary reference: Richter and others, 1975

Reporter(s): Travis L. Hudson (Applied Geology)

Last report date: $11 / 24 / 02$ 


\section{Site name(s): Unnamed (upper Horsfeld Creek)}

Site type: Prospect

ARDF no.: NB098

Latitude: 62.0541

Quadrangle: NB A-1

Longitude: 141.2600

\section{Location description and accuracy:}

This prospect is 1,000 feet north of the summit of peak 5945 between two unnamed north tributaries to Horsfeld Creek. The site is at an elevation of about 5,700 feet, about 0.2 mile east of the center of section 7, T. 3 N., R. 23 E. of the Copper River Meridian. This is locality 6 of Richter and others (1973), locality 51 of Richter and others (1975), and National Park Service locality WRST-85. Cobb and Richter (1980) included this locality as an 'Unnamed occurrence'. It is located to within a few hundred feet.

\section{Commodities:}

Main: $\mathrm{Cu}, \mathrm{Pb}$

Other: $\mathrm{Ag}, \mathrm{Au}, \mathrm{Zn}$

Ore minerals: Chalcopyrite

Gangue minerals: Quartz

\section{Geologic description:}

A 2-foot-wide quartz vein that contains chalcopyrite cuts volcanic breccia of the Cretaceous, Chisana Formation (Richter and others, 1973; 1975). A grab sample of the vein contained 0.04 parts per million (ppm) gold, 30 ppm silver, 10,000 ppm copper, 7,000 ppm lead, and 700 ppm zinc (Matson and Richter, 1971 [OFR 71-202]). This occurrence is about 5,000 feet northwest of the contact of the Chisana Formation and the midCretaceous, Klein Creek pluton (Richter and others, 1973; Richter, Lanphere, and Matson 1975).

\section{Alteration:}

Age of mineralization:

Mid-Cretaceous? The mineralization may be related to emplacement of the Klein Creek pluton which has a K/Ar date of 111 +/- 3.6 Ma (Richter, Lanphere, and Matson, 1975).

\section{Deposit model:}


Polymetallic veins (Cox and Singer, 1986; model 22c)

Deposit model number (After Cox and Singer, 1986 or Bliss, 1992):

$22 \mathrm{c}$

Production Status: None

Site Status: Inactive

Workings/exploration:

Production notes:

Reserves:

Additional comments:

The prospect is in the Wrangell-St. Elias National Preserve.

References:

Matson and Richter, 1971 (OFR 71-202); Richter and others, 1973; Richter and others, 1975; Richter, Lanphere, and Matson, 1975.

Primary reference: Matson and Richter, 1971 (OFR 71-202)

Reporter(s): Travis L. Hudson (Applied Geology)

Last report date: $11 / 24 / 02$ 


\section{Site name(s): Horsfeld}

Site type: Prospect

ARDF no.: NB099

Latitude: 62.0443

Quadrangle: NB A-1

Longitude: 141.2160

\section{Location description and accuracy:}

This prospect is in the headwaters of a small, unnamed north tributary to Horsfeld Creek; it is about 6,000 feet southwest of elevation 7253 (Joe) and 3,300 feet southsouthwest of peak 6895 . The site is near the center of the north boundary of the NW1/4 of section 16, T. 3 N., R. 23 E. of the Copper river Meridian. This is locality 7 of Richter and others (1973), locality 52 of Richter and others (1975), and National Park Service locality WRST-85 (unpublished data). Cobb and Richter (1980) included this prospect under the name 'Horsfeld'. It is located to within a few hundred feet.

\section{Commodities:}

Main: $\mathrm{Cu}$

Other: Ag, $\mathrm{Au}, \mathrm{Mo}$

Ore minerals: Chalcopyrite, magnetite, pyrite

Gangue minerals: Actinolite, potassium feldspar, quartz

\section{Geologic description:}

At the Horsfeld prospect, pyrite and chalcopyrite occur in quartz veinlets and as disseminations in monzonite and monzonite porphyry of the mid-Cretaceous, Klein Creek pluton (Richter and others, 1973; 1975). This porphyry copper and molybdenum deposit has a central 200- by 700-meter zone of potassium feldspar, actinolite, and magnetite alteration, and a 800 - by 1,500-meter outer zone of unspecified hydrothermal alteration. Surface samples contain less than 0.5 percent copper, and average 0.10 percent copper and less than 0.01 percent molybdenum (Hollister and others, 1975; Richter and others, 1975). Gold and silver were detected in some surface samples (Matson and Richter, 1971 [OFR 71-202]). The deposit is estimated to contain 60 million tons with an average grade of 0.20 percent copper and very low amounts of molybdenum (Richter and others, 1975). The deposit is in the Klein Creek pluton near its contact with Jurassic or Cretaceous siliciclastic rocks; the associated hydrothermal alteration zone extends across this contact (Richter and others, 1973).

\section{Alteration:}


This porphyry copper and molybdenum deposit has a central 200- by 700 -meter zone of potassium feldspar-actinolite-magnetite alteration, and a 800 - by 1,500-meter outer zone of unspecified hydrothermal alteration. Oxidation has resulted in abundant iron-staining.

\section{Age of mineralization:}

Mid-Cretaceous. The diorite of the Klein Creek pluton that hosts the deposits has a K/ Ar date of 111 +/- 3.6 Ma (Richter, Lanphere, and Matson, 1975).

\section{Deposit model:}

Porphyry Cu-Mo (Cox and Singer, 1986; model 21a)

\section{Deposit model number (After Cox and Singer, 1986 or Bliss, 1992): $21 \mathrm{a}$}

Production Status: None

Site Status: Inactive

\section{Workings/exploration:}

Surface exploration and some diamond drilling have been used to evaluated this deposit.

\section{Production notes:}

\section{Reserves:}

The deposit is estimated to contain 60 million tons with an average grade of 0.20 percent copper and very low amounts of molybdenum (Richter and others, 1975).

\section{Additional comments:}

The prospect is in the Wrangell-St. Elias National Preserve.

\section{References:}

Matson and Richter, 1971 (OFR 71-202); Richter and others, 1973; Richter and others, 1975; Hollister and others, 1975; Richter, Lanphere, and Matson, 1975; Cobb and Richter, 1980.

Primary reference: Richter and others, 1975

Reporter(s): Travis L. Hudson (Applied Geology)

Last report date: $11 / 24 / 02$ 


\section{Site name(s): Baultoff}

Site type: Prospect

ARDF no.: NB100

Latitude: 62.1054

Quadrangle: NB A-1

Longitude: 141.2159

\section{Location description and accuracy:}

This prospect is at an elevation of about 5,100 feet on a low ridge along the east side of a small south tributary valley to Baultoff Creek. It is 4,500 feet northwest of peak 6142 and 6,500 feet northeast of peak 7821. The site is in the SW1/4 of section 21, T. 4 N., R. 23 E. of the Copper River Meridian. This is locality 4 of Richter and others (1973), locality 53 of Richter and others (1975), and National Park Service locality WRST-87 (unpublished data). Cobb and Richter (1980) included this prospect under the name 'Baultoff'. It is located to within a few hundred feet.

\section{Commodities:}

Main: $\mathrm{Cu}$

Other: Ag, $\mathrm{Au}, \mathrm{Mo}$

Ore minerals: Chalcopyrite, pyrite

Gangue minerals: Albite, actinolite, quartz, sericite

\section{Geologic description:}

At the Baultoff prospect, disseminated pyrite and chalcopyrite occur in hornblende diorite and quartz porphyry of the mid-Cretaceous, Klein Creek pluton (Matson and Richter, 1971 [OFR 71-202]: Richter and others, 1975; Hollister and others, 1975). A 400- by 1,000-meter central altered zone is characterized by albite, chlorite, sericite and late anhydrite veins. It is within a 2,000- by 3,000-meter outer zone marked by abundant sericite and pyrite. Local actinolite veins and disseminations are present in the alteration zones. A post-mineralization fault bounds the alteration zone to the east. Surface samples contain less than 0.25 percent copper, and average 0.10 percent copper and less than 0.01 percent molybdenum (Richter and others, 1975). Low amounts of gold and silver are also present. The deposit is estimated to contain 160 million tons with an average grade of 0.20 percent copper and very low amounts of molybdenum (Richter and others, 1975). The diorite and porphyry that host the deposit are part of the Klein Creek pluton which has a K/Ar date of 111 +/- 3.6 Ma (Richter, Lanphere, and Matson, 1975).

\section{Alteration:}


A 400- by 1,000-meter central altered zone is characterized by albite, chlorite, sericite and late anhydrite veins. It is within a 2,000- by 3,000-meter outer zone marked by abundant sericite and pyrite. Local actinolite veins and disseminations are present in the alteration zones. A post-mineralization fault bounds the alteration zone to the east (Richter and others, 1973).

Age of mineralization:

Mid-Cretaceous; the diorite and porphyry that host the deposit are part of the Klein Creek pluton which has a K/Ar date of 111 +/- 3.6 Ma (Richter, Lanphere, and Matson, 1975).

\section{Deposit model:}

Porphyry Cu-Mo (Cox and Singer, 1986; model 21a)

Deposit model number (After Cox and Singer, 1986 or Bliss, 1992):

$21 \mathrm{a}$

Production Status: None

Site Status: Inactive

Workings/exploration:

Surface exploration and some diamond drilling have been used to evaluated this deposit.

\section{Production notes:}

\section{Reserves:}

The deposit is estimated to contain 160 million tons with an average grade of 0.20 percent copper and very low amounts of molybdenum (Richter and others, 1975).

\section{Additional comments:}

The prospect is in the Wrangell-St. Elias National Preserve.

\section{References:}

Matson and Richter, 1971 (OFR 71-202); Richter and others, 1973; Richter and others, 1975; Hollister and others, 1975; Richter, Lanphere, and Matson, 1975; Cobb and Richter, 1980.

Primary reference: Richter and others, 1975

Reporter(s): Travis L. Hudson (Applied Geology)

Last report date: $11 / 24 / 02$ 


\section{Site name(s): Unnamed (head of Little Creek)}

Site type: Occurrence

ARDF no.: NB101

Latitude: 62.0565

Quadrangle: NB A-1

Longitude: 141.1824

\section{Location description and accuracy:}

This occurrence is about 500 feet northeast of elevation 7253 (Joe) in the uppermost headwaters of Little Creek. Little Creek flows southeast to east Braye Lake. The site is in the NW1/4 of section 10, T. 3 N., R. 23 E. of the Copper River Meridian. This is locality 8 of Richter and others (1973), locality 54 of Richter and others (1975), and National Park Service locality WRST-87 (unpublished data). Cobb and Richter (1980) included this locality as an 'Unnamed occurrence'. It is located to within a few hundred feet.

\section{Commodities:}

Main: $\mathrm{Au}, \mathrm{Cu}, \mathrm{Mo}$

\section{Other:}

Ore minerals: Chalcopyrite, pyrite

\section{Gangue minerals:}

\section{Geologic description:}

This occurrence is a 50- by 100-meter iron-stained zone in which pyrite and chalcopyrite are disseminated in a small diorite porphyry stock (Richter and others, 1975). Surface samples average less than 0.10 percent copper and less than 0.01 percent molybdenum. The deposit is estimated to contain 4 million tons with an average grade of 0.20 percent copper and very low amounts of molybdenum. The diorite porphyry that hosts the deposit intrudes Jurassic or Cretaceous siliciclastic rocks and is considered to be Cretaceous or Tertiary in age (Richter and others, 1973). The mid-Cretaceous, Klein Creek pluton and the Baultoff (NB100) porphyry copper-molybdenum deposit that it hosts, are exposed about 5,000 feet southwest of this prospect. The Klein Creek pluton has a K/Ar date of 111 +/- 3.6 Ma (Richter, Lanphere, and Matson, 1975).

\section{Alteration:}

Oxidation; an iron-stained altered zone covers an area of 50 by 100 meters.

\section{Age of mineralization:}


Mid-Cretaceous? The diorite porphyry that hosts the deposit may be about the same age as the Klein Creek pluton which has a K/Ar date of 111 +/- 3.6 Ma (Richter, Lanphere, and Matson, 1975).

\section{Deposit model:}

Porphyry Cu-Mo (Cox and Singer, 1986; model 21a)

Deposit model number (After Cox and Singer, 1986 or Bliss, 1992):

$21 \mathrm{a}$

Production Status: None

Site Status: Inactive

Workings/exploration:

Some surface prospecting has taken place.

Production notes:

Reserves:

Additional comments:

The prospect is in the Wrangell-St. Elias National Preserve.

\section{References:}

Richter and others, 1973; Richter and others, 1975; Richter, Lanphere, and Matson, 1975; Cobb and Richter, 1980.

Primary reference: Richter and others, 1975

Reporter(s): Travis L. Hudson (Applied Geology)

Last report date: $11 / 24 / 02$ 


\section{Site name(s): Unnamed (north of lower Gravel Creek)}

Site type: Occurrence

ARDF no.: NB102

Latitude: 62.0759

Quadrangle: NB A-1

Longitude: 141.1259

\section{Location description and accuracy:}

This occurrence is on the south side of the ridge between lower Baultoff Creek and an unnamed north tributary to lower Gravel Creek. It is about 3,500 feet east-southeast of peak 6006 and 4,000 feet northeast of peak 5648. The site is at an elevation of about 5,200 feet in the SW1/4 of section 36, T. 4 N., R. 23 E. of the Copper River Meridian. This is locality 10 of Richter and others (1973), locality 55 of Richter and others (1975), and National Park Service locality WRST-88 (unpublished data). Cobb and Richter (1980) included this locality as an 'Unnamed occurrence'. It is located to within a few hundred feet.

\section{Commodities:}

Main: $\mathrm{Ag}, \mathrm{Au}, \mathrm{Cu}, \mathrm{Pb}$

Other: $\mathrm{Ba}$

Ore minerals: Barite, chalcopyrite, galena, tetrahedrite

Gangue minerals: Quartz

\section{Geologic description:}

A quartz-barite vein in upper Paleozoic marine argillite contains galena, chalcopyrite, and tetrahedrite (Matson and Richter, 1971 [OFR 71-202]; Richter and others, 1975). A sample of the vein contained 0.4 parts per million (ppm) gold, 5 ppm silver, $300 \mathrm{ppm}$ copper, 7,000 ppm lead, and 7,000 ppm zinc (Matson and Richter, 1971 [OFR 71-202]). The host rocks are part of a Permian marine sedimentary sequence (Richter and others, 1973).

\section{Alteration:}

Age of mineralization:

Permian or younger. The host rocks are part of a Permian marine sedimentary sequence (Richter and others, 1973).

\section{Deposit model:}


Quartz -barite vein with galena, chalcopyrite, and tetrahedrite

Deposit model number (After Cox and Singer, 1986 or Bliss, 1992):

Production Status: None

Site Status: Inactive

Workings/exploration:

Production notes:

Reserves:

Additional comments:

The occurrence is in the Wrangell-St. Elias National Preserve.

References:

Matson and Richter, 1971 (OFR 71-202); Richter and others, 1973; Richter and others, 1975; Cobb and Richter, 1980.

Primary reference: Matson and Richter, 1971 (OFR 71-202)

Reporter(s): Travis L. Hudson (Applied Geology)

Last report date: $11 / 24 / 02$ 


\section{Site name(s): Unnamed (south of lower Baultoff Creek)}

Site type: Occurrence

ARDF no.: NB103

Latitude: 62.0730

Quadrangle: NB A-1

Longitude: 141.0725

\section{Location description and accuracy:}

This occurrence is on the east nose of the ridge between lower Baultoff Creek and Gravel Creek. It is near elevation 4119 near the southeast corner of SE1/4 of section 31, T. 4 N., R. 24 E. of the Copper River Meridian. This is locality 9 of Richter and others (1973), locality 56 of Richter and others (1975), and National Park Service locality WRST-82 (unpublished data). Cobb and Richter (1980) included this locality as an 'Unnamed occurrence'. It is located to within a few hundred feet.

\section{Commodities:}

Main: $\mathrm{Ag}, \mathrm{Cu}$

Other: $\mathrm{Cr}, \mathrm{Ni}, \mathrm{V}, \mathrm{Zn}$

Ore minerals: Chalcopyrite

Gangue minerals: Calcite, quartz

\section{Geologic description:}

At this occurrence, quartz veins with calcite and minor chalcopyrite cut a small quartz monzonite stock and its volcanic country rocks (Matson and Richter, 1971 [OFR 71-202]; Richter and others, 1975). A grab sample of a quartz-calcite vein contained 7 parts per million (ppm) silver, 15,000 ppm copper, 700 ppm chromium, 150 ppm nickel, 200 ppm zinc, and 300 ppm vanadium (Matson and Richter, 1971 [OFR 71-202]). The diorite stock intrudes upper Paleozoic volcanic rocks and is inferred to be Cretaceous (Richter and others, 1973).

\section{Alteration:}

Age of mineralization:

Cretaceous or Tertiary; the diorite stock that hosts the deposit is inferred to be Cretaceous (Richter and others, 1973).

\section{Deposit model:}

Quartz-calcite veins with chalcopyrite 
Deposit model number (After Cox and Singer, 1986 or Bliss, 1992):

Production Status: No

Site Status: Inactive

Workings/exploration:

Production notes:

Reserves:

Additional comments:

The occurrence is in the Wrangell-St. Elias National Preserve.

References:

Matson and Richter, 1971 (OFR 71-202); Richter and others, 1973; Richter and others, 1975; Cobb and Richter, 1980.

Primary reference: Matson and Richter, 1971 (OFR 71-202)

Reporter(s): Travis L. Hudson (Applied Geology)

Last report date: $11 / 24 / 02$ 


\section{Site name(s): Unnamed (upper Carden Creek)}

Site type: Occurrence

ARDF no.: NB104

Latitude: 62.2367

Quadrangle: NB A-1

Longitude: 141.2757

\section{Location description and accuracy:}

This occurrence is at an elevation of about 3,350 feet where a winter trail crosses Carden Creek. The site is in the SE1/4 of section 2, T. 5 N., R. 22 E. of the Copper River Meridian. This is National Park Service locality WRST-78 (unpublished data) and the coordinates for this occurrence were provided by the National Park Service.

\section{Commodities:}

Main: $\mathrm{Au}$

Other:

Ore minerals: Gold

Gangue minerals:

\section{Geologic description:}

An unpublished National Park Service map and accompanying database identify this as a gold prospect. Moffit (1943) reported that a gold-bearing lode was explored in this area. The lode was near Carden Creek in schist or phyllite near a small gneissic granodiorite body. The host rocks are part of a Devonian metamorphic assemblage within and north of the Denali fault system (Richter and others, 1973; Richter, 1976). There are outcrops of granitic gneiss about 1.5 miles upstream of this site (Richter and others, 1973).

\section{Alteration:}

Age of mineralization:

Devonian or younger; the host rocks in this area are Devonian (Richter, 1976).

\section{Deposit model:}

Deposit model number (After Cox and Singer, 1986 or Bliss, 1992):

Production Status: Undetermined. 
Site Status: Inactive

Workings/exploration:

Moffit (1943) reports that a short adit explored this deposit.

Production notes:

\section{Reserves:}

Additional comments:

The prospect is in the Wrangell-St. Elias National Preserve.

\section{References:}

Moffit, 1943; Richter and others, 1973; Richter, 1976.

Primary reference: Moffit, 1943

Reporter(s): Travis L. Hudson (Applied Geology)

Last report date: $11 / 24 / 02$ 


\section{Site name(s): Beaver}

Site type: Prospect

ARDF no.: NB105

Latitude: 62.1703

Quadrangle: NB A-1

Longitude: 141.1860

\section{Location description and accuracy:}

This prospect is in the headwaters of Ivereson Creek at an elevation of about 5,400 feet. It is about 4,500 feet southwest of elevation 6661 (Baultoff). The prospect is about 0.1 mile northeast of the center of section 32, T. 5 N., R. 23 E. of the Copper River Meridian. This is National Park Service locality WRST-80 (unpublished data) and the coordinates of this prospect were provided by the National Park Service.

\section{Commodities:}

Main: $\mathrm{Au}, \mathrm{Cu}$

\section{Other:}

Ore minerals:

Gangue minerals:

\section{Geologic description:}

An unpublished National Park Service map and accompanying database identify this as a gold and copper prospect. The bedrock in Ivereson Creek is Jurassic or Cretaceous siliciclastic rocks; intrusions have not been mapped in this drainage (Richter and others, 1973).

\section{Alteration:}

Age of mineralization:

Jurassic or younger. Bedrock in Ivereson Creek is Jurassic or Cretaceous siliciclastic rocks (Richter and others, 1973).

\section{Deposit model:}

Deposit model number (After Cox and Singer, 1986 or Bliss, 1992):

Production Status: None 
Site Status: Inactive

Workings/exploration:

Production notes:

Reserves:

Additional comments:

The prospect is in the Wrangell-St. Elias National Preserve.

References:

Richter and others, 1973.

Primary reference: This record

Reporter(s): Travis L. Hudson (Applied Geology)

Last report date: 11/24/02 


\section{Site name(s): Susan}

Site type: Prospect

ARDF no.: NB106

Latitude: 62.1277

Quadrangle: NB A-1

Longitude: 141.1098

\section{Location description and accuracy:}

This prospect is at an elevation of about 5,000 feet near a small saddle, 2,000 feet north of Fourmile Creek. It is about 1,800 feet west-northwest of elevation 5227 in the NE1/4 of section 13, T. 4 N., R. 23 E. of the Copper River Meridian. This is National Park Service locality WRST-81 (unpublished data) and the coordinates of this prospect were provided by the National Park Service.

\section{Commodities:}

Main: $\mathrm{Ag}, \mathrm{Au}, \mathrm{Cu}, \mathrm{Pb}$

\section{Other:}

\section{Ore minerals:}

\section{Gangue minerals:}

\section{Geologic description:}

An unpublished National Park Service map and accompanying database identify this as a gold, silver, copper, and lead prospect. Eleven lode claims were active from 1974 to 1980. The prospect is close to small elongate bodies of porphyritic diorite and mafic diorite that intrude Jurassic or Cretaceous siliciclastic rocks (Richter and others, 1973). Both the intrusions and the host sedimentary rocks are in fault contact with Triassic, Nikolai Greenstone to the south.

\section{Alteration:}

\section{Age of mineralization:}

Jurassic or younger; the host rocks may be as old as Jurassic but mineralization could be related to younger intrusions or faults.

\section{Deposit model:}

Deposit model number (After Cox and Singer, 1986 or Bliss, 1992): 
Production Status: None

Site Status: Inactive

Workings/exploration:

At least surface exploration has occurred in this area.

\section{Production notes:}

\section{Reserves:}

\section{Additional comments:}

The prospect is in the Wrangell-St. Elias National Preserve.

\section{References:}

Richter and others, 1973.

Primary reference: This record

Reporter(s): Travis L. Hudson (Applied Geology)

Last report date: $11 / 24 / 02$ 


\section{Site name(s): Unnamed (in south tributary to Fourmile Creek)}

Site type: Prospect

ARDF no.: NB107

Latitude: 62.1040

Quadrangle: NB A-1

Longitude: 141.1100

\section{Location description and accuracy:}

This prospect is in the headwaters of an unnamed south tributary to Fourmile Creek. It is at an elevation of about 5,100 feet , 2,000 feet south-southeast of peak 5574, and 2,500 feet west of elevation 5202. The site is in the SE1/4 of section 24, T. 4 N., R. 23 E. of the Copper River Meridian. This is National Park Service locality WRST-82 (unpublished data) and the coordinates of this prospect were provided by the National Park Service.

\section{Commodities:}

Main: $\mathrm{Ag}, \mathrm{Au}, \mathrm{Cu}, \mathrm{Pb}$

\section{Other:}

Ore minerals: Chalcopyrite

Gangue minerals: Quartz

\section{Geologic description:}

An unpublished National Park Service map and accompanying database identify this as a gold, silver, copper, and lead prospect. It apparently is the prospect reported by Moffit and Knopf (1909) as being near the head of Fourmile Creek. Several quartz veins up to 30 feet thick contain sparse chalcopyrite. Some masses of the quartz form silicified and brecciated zones that enclose large angular blocks of country rock. The country rock includes shale and argillite intruded by a porphyry (Moffit and Knopf, 1909). This description seems to match the description of the Susan prospect (NB106) better than it does this prospect. The ridge above Baultoff Creek near this prospect is mantled by Quaternary surficial deposits that overlie upper Paleozoic volcanic rocks (Richter and others, 1973).

\section{Alteration:}

Silicification.

\section{Age of mineralization:}

\section{Deposit model:}

Polymetallic veins? (Cox and Singer, 1986; model 22c) 
Deposit model number (After Cox and Singer, 1986 or Bliss, 1992):

$22 \mathrm{c}$ ?

Production Status: None

Site Status: Inactive

Workings/exploration:

At least some prospecting here.

\section{Production notes:}

\section{Reserves:}

Additional comments:

The prospect is in the Wrangell-St. Elias National Preserve.

\section{References:}

Moffit and Knopf, 1909; Richter and others, 1973.

Primary reference: This record

Reporter(s): Travis L. Hudson (Applied Geology)

Last report date: $11 / 24 / 02$ 


\section{Site name(s): Eureka Gulch}

Site type: Occurrence

ARDF no.: NB108

Latitude: 62.0566

Quadrangle: NB A-1

Longitude: 141.0054

\section{Location description and accuracy:}

This prospect is at the head of Eureka Gulch, a south tributary to Lamb Creek. The occurrence is at an elevation of about 4,500 feet, near the northeast corner of section 9, T. 3 N., R. 24 E. of the Copper River Meridian. This is National Park Service locality WRST-90 (unpublished data) and the coordinates of this occurrence were provided by the National Park Service.

\section{Commodities:}

Main: $\mathrm{Ag}, \mathrm{Au}, \mathrm{Cu}, \mathrm{Pb}, \mathrm{Zn}$

\section{Other:}

Ore minerals: Chalcopyrite, galena, sphalerite

\section{Gangue minerals:}

\section{Geologic description:}

An unpublished National Park Service map and accompanying database identify this as a gold, copper, lead and zinc prospect. It appears to be a prospect described by Moffit and Knopf (1909) at the head of Eureka Creek, near the international boundary. A number of quartz veins, 4 to 12 feet thick, contain a small amount of chalcopyrite and locally are copper-stained. At least one quartz vein, localized in a shear zone up to 8 feet wide, contains argentiferous galena and sphalerite. This deposit was explored by a 60-foot long adit by 1909 (Moffit and Knopf, 1909). A major fault that trends along Eureka Creek juxtaposes upper Paleozoic volcanic rocks to the south against Jurassic or Cretaceous siliciclastic rocks to the north. In this area, the bedded rocks are locally intruded by dikes and small irregular bodies of Cretaceous or Tertiary, porphyritic diorite and mafic diorite (Richter and others, 1973).

\section{Alteration:}

Silicification and oxidation.

\section{Age of mineralization:}

Cretaceous or Tertiary? Mineralization may be related to emplacement of the Creta- 
ceous or Tertiary intrusive rocks.

\section{Deposit model:}

Polymetallic veins? (Cox and Singer, 1986; model 22c)

Deposit model number (After Cox and Singer, 1986 or Bliss, 1992):

$22 \mathrm{c}$

Production Status: Undetermined.

Site Status: Inactive

Workings/exploration:

Surface prospecting has been done in this area and at least one 60-foot- long adit is reported to have explored a quartz vein (Moffit and Knopf, 1909).

Production notes:

\section{Reserves:}

\section{Additional comments:}

The prospect is in the Wrangell-St. Elias National Preserve.

\section{References:}

Moffit and Knopf, 1909; Richter and others, 1973.

Primary reference: Moffit and Knopf, 1909

Reporter(s): Travis L. Hudson (Applied Geology)

Last report date: $11 / 24 / 02$ 


\section{Site name(s): Horsfeld Creek}

Site type: Prospect

ARDF no.: NB109

Latitude: 62.0197

Quadrangle: NB A-1

Longitude: 141.1800

\section{Location description and accuracy:}

This placer prospect is on Horsfeld Creek, about 1.9 miles upstream of its confluence with Beaver Creek and 1.2 miles west of Braye Pass. The site is in the SW1/4 of section 22, T. 3 N., R. 23 E. of the Copper River Meridian. This is National Park Service locality WRST-91 (unpublished data) and the coordinates for this prospect were provided by the National Park Service.

\section{Commodities:}

Main: $\mathrm{Ag}, \mathrm{Au}$

\section{Other:}

Ore minerals: Gold

\section{Gangue minerals:}

\section{Geologic description:}

An unpublished National Park Service map and accompanying database identify this as a gold and silver, placer prospect. Horsfeld Creek drains an area containing polymetallic veins and porphyry copper prospects (NB098 and NB099). Granitic rocks of the Cretaceous Klein Creek pluton intrude Cretaceous volcanic rocks and Jurassic or Cretaceous siliciclastic rocks in the drainage area (Richter and others, 1973).

\section{Alteration:}

Age of mineralization:

Quaternary.

\section{Deposit model:}

Placer Au (Cox and Singer, 1986; model 39a)

Deposit model number (After Cox and Singer, 1986 or Bliss, 1992):

$39 a$ 
Production Status: Undetermined.

Site Status: Inactive

Workings/exploration:

At least some surface prospecting was probably done in this area.

\section{Production notes:}

\section{Reserves:}

\section{Additional comments:}

The prospect is in the Wrangell-St. Elias National Preserve.

\section{References:}

Richter and others, 1973.

Primary reference: This record

Reporter(s): Travis L. Hudson (Applied Geology)

Last report date: $11 / 24 / 02$ 


\section{References}

Capps, S. R., 1915, Mineral resources of the Chisana-White River district: U. S. Geological Survey Bulletin 622, p. 189-228.

Capps, S.R., 1916, The Chisana-White River district, Alaska: U.S. Geological Survey Bulletin 630, 130 p.

Cobb. E.H., and Richter, D.H., 1980, Summaries of data on and list of references to metallic and selected nonmetallic mineral deposits in the Nabesna quadrangle, Alaska: U.S. Geological Survey Open-File Report 80-927, 117 p.

Cox, D.P., and Singer, D.A., eds., 1986, Mineral deposit models: U.S. Geological Survey Bulletin 1992,379 p.

Foley, J.Y., Barker, J. C., and Brown, L. L., 1985, Critical and strategic minerals investigation in Alaska; chromium: U.S. Bureau of Mines Open-File Report, 97-85, 1 sheet, 54 p.

Hollister, V.F., Anzalone, S.A., and Richter, D.H., 1975, Porphyry copper belts of southern Alaska and contiguous Yukon Territory: Canadian Mining and Metallurgical Bulletin, v. 68, no. 756, p. 104-112

Linn, G. W., 1973, Geology of Orange, Hill, Alaska: Berkeley, California, University of California, M. A. thesis 119 p.

Lowe, P.C., Richter, D. H., Smith, R. L., and Schmoll, H. R., 1982, Geologic map of the Nabesna B-5 quadrangle, Alaska: U.S. Geological Survey Geologic Quadrangle Map GQ-1566, scale 1:63,360.

MacKevett, E. M., Jr., Cox, D. P., Potter, R. W., III, and Silberman, M. L., 1997, Kennecott-type deposits in the Wrangell Mountains, Alaska: High-grade copper ores near a basalt-limestone contact, in Miller, L. D., and Goldfarb, R.J., eds., Mineral deposits of Alaska: Economic Geology Monograph 9, p. 66-89.

Matson, N.A., and Richter, D.H., 1971, Geochemical data from the Nabesna A-1 quadrangle, Alaska: U.S. Geological Survey Open-File Report 71-202, 10 p.

Matson, N.A., and Richter, D.H., 1971, Geochemical data from the Nabesna C-5 quadrangle, Alaska: U.S. Geological Survey Open-File Report 71-204, 10 p.

Mendenhall, W.C., and Schrader, F. C., 1903, The mineral resources of the Mount Wrangell district, Alaska: U. S. Geological Survey Professional Paper 15, 71 p.

Miller, T. P., 1994, Pre-Cenozoic plutonic rocks in mainland Alaska, in Plafker, George, and Berg, H. C., eds., The Geology of Alaska: Boulder, Colorado, Geological Society of America, The Geology of North America, v. G-1, p. 535-554.

Moffit, F.H., 1943, Geology of the Nutzotin Mountains, Alaska, with a section on The igneous rocks, by R. C. Wayland, and Gold deposits near Nabesna, by R. C. Wayland, 1943: U.S. Geological Survey Bulletin 933-B, p. 103-199.

Moffit, F.H., 1944, Mining in the northern Copper River region, Alaska: U.S. Geological Survey Bulletin 943-B, p. $25-47$.

Moffit, F.H., 1954, Geology of the eastern part of the Alaska Range and adjacent area: U.S. Geological Survey Bulletin 989-D, p. 65-218.

Moffit, F.H., and Knopf, Adolph, 1909, Mineral resources of the Nabesna-White River district: U.S. Geological Survey Bulletin 379-E, p. 161-180. 
Newberry, R. J., Allegro, G. L., Cutler, S. E., Hagen-Levelle, J. H., Adams, D. D., Nicholson, L. C., Weglarz, T. B., Bakke, A. A., Clautice, K. H., Coulter, G. A., Ford, M. J., Meyers, G. L., and Szumigala, D. J., 1997, Skarn deposits of Alaska, in Miller, L. D., and Goldfarb, R.J., eds., Mineral deposits of Alaska: Economic Geology Monograph 9, p. 355-395.

Pilgrim, E. R., 1931, Report on cooperation between the Territory of Alaska and the United States in making mining investigations and in inspection of mines for the biennium ending March 3 1, 1931, p. 60-76.

Richter, D.H., 1964, Geology and mineral deposits of the Ahtell Creek area, Slana District, south-central Alaska: Alaska Division of Geological and Geophysical Surveys Geologic Report 6, 1 sheet, scale 1:31,680, 17 p.

Richter, D.H., 1966, Geology of the Slana district, south-central Alaska: Alaska Division of Geological and Geophysical Surveys Geological Report 21, 3 sheets, scale 1:63,360, 36 p.

Richter, D.H., 1967, Geology of the upper Slana-Mentasta Pass area, south-central Alaska: Alaska Division of Geological and Geophysical Surveys Geological Report 30, 1 sheet, scale 1:63,360, 27 p.

Richter, D.H., 1970, A corundum occurrence in the eastern Alaska Range, Alaska: U.S. Geological Survey Professional Paper 700-C, p. C98-C102.

Richter, D.H., 1971, Reconnaissance geologic ma, and section of the Nabesna A-3 quadrangle, Alaska: U.S. Geological Survey Miscellaneous Investigations Series Map 1-655, scale 1:63,360.

Richter, D.H., 1971, Reconnaissance geologic map and section of the Nabesna B-4 quadrangle, Alaska: U.S. Geological Survey Miscellaneous Investigations Series Map 1-656, scale 1:63,360.

Richter, D.H., 1973, Reconnaissance geologic map of the Nabesna A-1 quadrangle, Alaska: U.S. Geological Survey Miscellaneous Investigations Series Map 1-789, scale 1:63,360.

Richter, D.H., 1975, Reconnaissance geologic map of the Nabesna B-3 quadrangle, Alaska: U.S. Geological Survey Miscellaneous Investigations Series Map I-904, scale 1:63,360.

Richter, D. H., 1976, Geologic map of the Nabesna quadrangle, Alaska: U. S. Geological Survey Miscellaneous Investigations Series Map I-932, scale 1:250,000.

Richter, D.H., and Jones, D.L., 1973, Reconnaissance geologic map of the Nabesna A-2 quadrangle, Alaska: U. S. Geological Survey Miscellaneous Investigations Series Map I-749, scale 1:63,360.

Richter, D. H., Lanphere, M. A., and Matson, N. A., 1975, Granitic plutonism and metamorphism, eastern Alaska Range, Alaska: Geological Society of America Bulletin, v. 86, p. 819-829.

Richter, D.H., and Matson, N.A., 1968, Distribution of gold and some base metals in the Slana area, eastern Alaska Range, Alaska: U.S. Geological Survey Circular 593, 20 p.

Richter, D.H., and Matson, N.A., 1969, Geochemical data from the Nabesna A-3 quadrangle, Alaska: U.S. Geological Survey Open-File Report 69-223, 5 p., 1 sheet, scale 1:63,360.

Richter, D.H., and Matson, N.A., 1970, Geochemical data from the Nabesna A-2 quadrangle, Alaska: U.S. Geological Survey Open-File Report 70-275, 12 p., 1 sheet, scale 1:63,360.

Richter, D.H., and Matson, N.A., 1970, Geochemical data from the Nabesna A-4 quadrangle, Alaska: U.S. Geological Survey Open-File Report 70-276, 14 p., 1 sheet, scale 1:63,360.

Richter, D.H., and Matson, N.A., 1972, Metallic mineral resources map of the Nabesna quadrangle, Alaska: U.S. 
Geological Survey Miscellaneous Field Studies Map MF-422, scale 1:250,000.

Richter, D.H., Matson, N. A., and Schmoll, H. R., 1973, Reconnaissance geologic map of the Nabesna A-1 quadrangle, Alaska: U.S. Geological Survey Miscellaneous Investigations Series Map 1-807, scale 1:63,360.

Richter, D.H., Singer, D. A., and Cox, D. P., 1975, Mineral resources map of the Nabesna quadrangle, Alaska: U.S. Geological Survey Miscellaneous Field Studies Map MF-655-K, scale 1:250,000.

Richter, D.H., Matson, N. A., and Schmoll, H. R., 1976, Geologic map of the Nabesna C-4 quadrangle, Alaska: U.S. Geological Survey Geologic Quadrangle Map GQ-1303, scale 1:63,360.

Richter, D.H., and Schmoll, 1973, Geologic Map of the Nabesna C-5 quadrangle, Alaska: U.S. Geological Survey Geologic Quadrangle Map GQ- 1062, scale 1:63,360.

Smith, P. S., 1939, Mineral industry of Alaska in 1937: U. S. Geological Survey Bulletin 910-A, p. 1-113.

U.S. Bureau of Mines, 1994, Mineral Information Location System Database: U.S Bureau of Mines Alaska Field Operations Center, Anchorage, AK.

U.S. Bureau of Mines, 1995, Spatial data extracted from the Minerals Availability System/Minerals Industry Location System (MAS/MILS): U. S. Bureau of Mines Special Publication 12-95, CD-ROM.

Van Alstine, R.E., and Black, R.F., 1944, Mineral deposits at Orange Hill, Alaska: U.S. Geological Survey Open-File Report 76, 1 sheet, 16 p.

Wayland, R.C., 1943, Gold deposits near Nabesna: U.S. Geological Survey Bulletin 933-B, p. 103-199.

Weglarz, T. B., 1991, Skarn genesis at the Nabesna mine, southcentral Alaska: Fairbanks, Alaska, University of Alaska, M. S. thesis, 173 p. 